\title{
A hundred introductions to semiotics, for a million students: Survey of semiotics textbooks and primers in the world
}

\author{
Kalevi Kull, Olga Bogdanova, Remo Gramigna, Ott Heinapuu, Eva Lepik, \\ Kati Lindström, Riin Magnus, Rauno Thomas Moss, Maarja Ojamaa, \\ Tanel Pern, Priit Põhjala, Katre Pärn, Kristi Raudmäe, Tiit Remm, \\ Silvi Salupere, Ene-Reet Soovik, Renata Sõukand, Morten Tønnessen, \\ Katre Väli \\ Department of Semiotics \\ University of Tartu \\ Jakobi 2, 51014 Tartu, Estonia'
}

\begin{abstract}
In order to estimate the current situation of teaching materials available in the field of semiotics, we are providing a comparative overview and a worldwide bibliography of introductions and textbooks on general semiotics published within last 50 years, i.e. since the beginning of institutionalization of semiotics. In this category, we have found over 130 original books in 22 languages. Together with the translations of more than 20 of these titles, our bibliography includes publications in 32 languages. Comparing the authors, their theoretical backgrounds and the general frames of the discipline of semiotics in different decades since the 1960s makes it possible to describe a number of predominant tendencies. In the extensive bibliography thus compiled we also include separate lists for existing lexicons and readers of semiotics as additional material not covered in the main discussion. The publication frequency of new titles is growing, with a certain depression having occurred in the 1980s. A leading role of French, Russian and Italian works is demonstrated.
\end{abstract}

Keywords: history of semiotics, semiotics of education, literature on semiotics, teaching of semiotics

1Correspondence should be sent to kalevi.kull@ut.ee. 


\section{Introduction}

The purpose of this review originates from the tasks that every teacher of semiotics faces: What textbook should be used? What should be the essential literature recommended to students in introductory classes on semiotics? Or if the goal is to write an original textbook, which of the earlier ones could be used as best? Introductory courses in semiotics are taught in many universities internationally, and their number tends to grow as a part of study programmes in linguistics, media and communication studies, performance analysis, marketing, cultural theory, but also cognitive science, philosophy of science, biology, etc., along with a few extensive programmes entirely focused on semiotics. An increase in the number of introductory courses is especially notable in the countries where some universities provide a degree in semiotics, e.g., Italy, Estonia, Denmark, Finland, Brazil (Kull 2009). ${ }^{2}$ What all these issues demonstrate is the need for an overview of semiotics textbooks. Indeed, at the University of Tartu as a semiotics centre, with its full-scope programme in semiotics (including majors on the bachelor's, master's, and doctoral levels), the need to address this topic is particularly acutely felt. Thus, our purpose is to give a (pluri)review of all existing introductions to semiotics. According to our knowledge, no such extensive reviews of the existing semiotics textbooks have been published so far. The question of semiotics textbooks has been only briefly discussed earlier (e.g., Danesi 1991; Kull, Salupere, Torop 2009; Nöth 2010). In some textbooks, a selected bibliography of the existing textbooks is given (e.g., Voigt 2008: 292-294), sometimes in combination with a more general overview of semiotics and its perspectives in various countries (e.g., Alvarez Sanagustín et al. 1992: 3-11), sometimes as part of the suggested materials for further reading (Volli 2000; Gensini 2002; Chandler 2002, etc.) What is worth mentioning separately is Klinkenberg's (1996) and Voigt's (2008) introductions, that also include lists of dictionaries, reviews, journals of semiotics, etc. at the end of the book.

In the present collective review, we attempt to cover all introductory textbooks of semiotics in the world we could find. Having formulated this aim, we certainly assume that our list of textbooks is neither complete nor all-encompassing - we have not been able to compile a full list for all languages. However, we expect the list to be quite exhaustive at least concerning the books published in English, as well as, e.g., German, Russian, French, Italian, Japanese, Finnish, Estonian. We have also included the translations we are aware of, although their record is seemingly quite incomplete. ${ }^{3}$

We have limited this review to the books which explicitly identify themselves as books about semiotics (or, sometimes, semiology), attempt to cover semiotics as a

2 On teaching of semiotics, see also Pelc 1992; Spartz, Kramer 2006; Nöth 2010; Kull, Väli 2011.

3 The 19 authors of this article were able together to cover most of the languages in which textbooks of semiotics have been published. 
whole, i.e. the general introductions, and were published between 1960 and 2010. This means that we have not included textbooks that deal with some particular branch of semiotics, e.g. only with sociosemiotics (e.g., Leeuwen 2005), visual semiotics (e.g., Sonesson 1988), biosemiotics (e.g., Hoffmeyer 2008), or literary semiotics (e.g., Simpkins 2001), semiotics of film, theatre, etc. Furthermore, we have not included various monographs on particular approaches to semiotics which offer a theoretical overview but were not written as introductory textbooks (for instance Deely 2001; Culler 1975, 1981; Petrilli, Ponzio 2005; many volumes from the series Advances to Semiotics; Approaches to Applied Semiotics; Semiotics, Cognition, Communication; Tartu Semiotics Library; works on the methods of semiotics, e.g. Manning 1987, etc.; works about the major figures in semiotics, e.g., Krampen et al. 1981; 1987). However, introductory textbooks that attempt to give a general overview while departing from a particular field or approach in semiotics (e.g., Peircean and pragmatist perspective in Tejera 1988; or semiotics of text in Pozzato 2004; or non-verbal communication in Leeds-Hurwiz 1993) are included. Further categories of publications that generally transcend the scope of this review include monographs on semiotics and its relation to other disciplines, monographs on the semiotic theory of a particular scholar or tradition, and articles or book chapters regardless of their relevance.

In addition to monographic textbooks, there are handbooks like encyclopedias, dictionaries, anthologies and readers (also compendia of reading materials for particular courses) that an introductory course in semiotics certainly has to take into account. Up to now, the number of this type of publications is relatively scant, which is why we briefly list them in Sections 2 and 3, before the review of textbooks and introductions.

\section{Encyclopedias and dictionaries}

The three-volume Encyclopedic Dictionary of Semiotics (published in three editions: Sebeok 1986, 1994; Sebeok, Danesi 2010), which gives a thorough overview of the terminology of semiotics in all its fields, has been a seminal work of reference ever since it first appeared. It was meant as a replacement for an earlier volume by A. J. Greimas and J. Courtés' (1966, 1982, 1993), Semiotics and Language: An Analytical Dictionary, a work that, despite its title, is not limited to the theory of language, but succeeds in providing a quite broad definition of semiotics, while relying mainly on the tradition of semiology. Other early dictionaries of semiotics include Bense, Walther (1973) and Rey-Debove (1979).

The world's most extensive encyclopedia of semiotics is the monumental fourvolume bilingual (English and German) encyclopedia edited by Posner et al. (1997). This weighty work attempts to exhaust all possible types of semiotics organized by subject areas, historically and geographically. 
Winfried Nöth's Handbook of Semiotics (Nöth 1985, 1990, 2000) is written by a single author but owing to its historical approach and unusually profound and diverse references it belongs to the category of encyclopedias rather than that of monographs. This work has appeared in German (1985, 2000), English (1990), Croatian (2004) and Bahasa (2006).

Paul Bouissac's Encyclopedia of Semiotics (Bouissac 1998) is a good companion volume to the former ones due to its compactness. Further, Bouissac has started a Semiotics Encyclopedia Online. ${ }^{4}$ Paul Cobley's (Cobley 2001, 2010) reference book reflects the recent changes in the field. ${ }^{5}$ The International Handbook of Semiotics (Trifonas 2015) also dwells on some recent developments of semiotics.

In addition, some dictionaries with a large number of short entries on semiotic terms (Rey-Debove 1979; Dutz 1979; Colapietro 1993; Martin, Ringham 2000, 2006), and some lexicons of smaller distribution (Bellert, Ohlin 1978; Thellefsen, Sørensen 2007) have been published. ${ }^{6}$ Dimitriou (1978-1987) has published semiotic dictionaries in Greek; Ablali and Ducard (2009) in French: In Russian, Levchenko and Salupere (1999) and Mahlina (2009) have compiled smaller dictionaries with specific foci. Dictionary of General Semiotics which includes around 600 terms has been compiled by Louis Hébert (2012, only on the web).?

\section{Anthologies and readers}

This category comprises various anthologies and readers which assemble full key texts or extracts from significant texts in semiotics, often arranged in chronological order. Among the works of this type, the first one - and still one of the best - to be published in English was an introductory anthology by Robert E. Innis (1985) that also contains introductory comments on classic texts. Another collection titled Frontiers in Semiotics (Deely et al. 1986) is supplied with an introduction by John Deely and characterized by a broad treatment of semiotics. Another early anthology was compiled by Martin Blonsky (1985). In addition to excerpts from canonical texts, the laconically entitled four-volume

\footnotetext{
4 Its address is http://www.semioticon.com/seo/.

5 All these encyclopedias include exhaustive bibliographies. At least one annotated bibliography on general semiotics (in Portuguese) has been published as a separate title (Nöth, Santaella 1999). Achim Eschbach has compiled extensive bibliographies on semiotics (Eschbach 1974; Eschbach, Rader 1976; Eschbach, Eschbach-Szabó 1986, 2 vols.). A separate bibliography exists on the early Tartu-Moscow School (Eimermacher, Shishkoff 1977).

6 We have not included dictionaries which do not explicitly cover semiotics, despite including many semiotic terms (e.g., O’Sullivan et al. 1994.)

7 Hébert, Louis 2012. Dictionnaire de sémiotique générale (http://www.signosemio.com/ documents/dictionnaire-semiotique-generale.pdf).
} 
Semiotics (Boklund-Lagopoulou et al. 2002) embraces a more recent period, including post-structuralism and postmodernism. Yet another large four-volume anthology bearing the same title Semiotics (Bundgaard, Stjernfelt 2010) pursues similar tasks. The Russian language has produced a Tartu-Moscow School reader (Matejka et al. 1977, with an English foreword), and the many-faceted anthologies compiled by Juri Stepanov (Stepanov 1983, 2001). Clarke's coursebook on Peircean semiotics of logic and language (Clarke 1987, see below) is accompanied by a reader (Clarke 1990); the two books can be used as instruction materials for a single course. Fedorova's anthology (Fedorova 2005) and textbook (Fedorova 2004) are connected in a similar way. Canadian professors of semiotics have compiled two less voluminous collections of texts specifically designed for introductory courses in semiotics (Danesi, Santeramo 1999; Perron, Danesi 2003). An outstanding collection, adopted as a coursebook in several university courses in semiotics in Italian universities, is the double-volume anthology Semiotica in Nuce (Fabbri, Marrone 2000; 2001). There exist also anthologies in Arabic (Abu Zayd, Kasim 1986) and in German (Mersch 1998). Besides the anthologies of general semiotics, there are some of particular branches of semiotics, for instance one of the semiotics of culture by Janus and Mayenowa (1975), and Matejka et al. (1977). Recently, the first anthologies of biosemiotics (Favareau 2010) and zoosemiotics (Maran et al. 2011) were published.

All in all, approximately twenty readers and anthologies in general semiotics have been published so far.

\section{Textbooks and introductions to semiotics: A comparative historical overview}

The third group covers general introductions and textbooks in semiotics. These are usually monographic works which articulate the author's point of view and understanding of semiotics. A number of introductions have been created in the course of teaching, driven by the practical need for study aids.

Leaving aside the otherwise influential books by Ogden and Richards (1923), Morris (e.g. 1946), as well as older classics such as Peirce, Saussure, Welby and few others, it can be noticed that the real institutionalization of semiotics started only in the 1960s, and was accompanied by the publication of the first general introductory books on semiotics.

Below, we provide brief synopses of a number of textbooks found in our bibliography, with a focus on the central notions, key authors discussed, the general structure and the proposed target of the books. We have grouped these into four periods: (1) from the 1960s to the early 1970s; (2) the late 1970s and the 1980s; (3) the 1990s and (4) the 2000s up to the present.

We have limited our bibliography to books published as hard copies. However, there exist also complete textbooks of semiotics that have been published only on the 
web - Tuomo Jämsäs introduction in Finnish, ${ }^{8}$ and Louis Hébert's introduction to applied semiotics in English. ${ }^{9}$

\subsection{First comprehensive introductions: the 1960 s and early 1970 s}

Textbooks of semiotics do not appear in a vacuum; their publication reflects the roots of this discipline in different contexts. In the 1960s, semiotics had strong centres in French-, Italian-, German- and Russian-speaking cultures. Thus, it is to be expected that these were the main languages in which the first introductory semiotics books were written and published. Among these seminal textbooks one can find the introductions in French by Barthes (1964), Mounin (1970) and Guiraud (1971); introductions in Russian by Vetrov (1968) and Stepanov (1971); introductions in German by Bense (1967) and Nöth (1975); and one in Italian by Eco (1968). Among the books produced in the first decade of institutionalized semiotics were also a Chinese introduction to semiotics by Xiuhuang He (1965), and a Japanese one by Yoshio Sezai (1970).

It is remarkable that no English-language introductory books to semiotics were written at that time; furthermore, the first translations of the books of this period were not made into English either, except for the translations of Barthes 1964, appearing in English in 1967 and 1968.

\section{- Barthes's Eléments de sémiologie [Elements of Semiology] (1964)}

This small book by Roland Barthes was the earliest in this group. It introduces the terminology of the French structuralist school departing from Saussure. The pioneering role of the work has been pointed out by Umberto Eco:

In 1964 Barthes published his "Elements of Semiology" in the fourth issue of the journal Communications. I consider it necessary to recall here what this short text, that was not aimed at anything big and that was a compilation by nature, meant for all of us who were fascinated by semiotics - it is this writing that forced us to work out our own approaches to sign systems and communicative processes, while Barthes himself was moving away from pure theory. If this book by Barthes had not existed, we would have managed to do much less. (Eco 1998[1968]: 4)

Barthes considers semiology as a part of translinguistics studying "great signifying unities of discourse" (Barthes 1995[1964]: 11), an area that is still trying to take definite

\footnotetext{
8 Jämsä, Tuomo, Semiotiikan perusteet (http://oppimateriaalit.internetix.fi/fi/avoimet/ 8kieletkirjallisuus/semiotiikka/).

9 Hébert, Louis 2011[2005]. Tools for Text and Image Analysis: An Introduction to Applied Semiotics (http://www.signosemio.com/documents/Louis-Hebert-Tools-for-Texts-and-Images. pdf); the 2011 version with the collaboration of Nicole Everaert-Desmedt.
} 
shape. The elements of semiology presented in the book are extracted from linguistics: language and speech, signifier and signified, syntagm and system, denotation and connotation. After a theoretical explanation of his key notions, comparing linguistic and semiological approaches, Barthes introduces the semiological prospects of these terms (for example, the garment and the food systems). Barthes also discusses the problems of these notions when describing various systems. He considers reconstituting the functioning of the systems of significations other than language to be the aim of semiological research.

His main point of departure is Saussure's work, but he also refers to several other classics of semiotics such as Peirce, Hjelmslev and Morris, important authors being also Lévi-Strauss, Lacan, Merleau-Ponty and André Martinet; he also mentions G. Mounin, P. Guiraud, A. J. Greimas. The work of Henri Wallon (1942) on sign typology and some ideas of Roman Jakobson (see, e.g., Barthes 1995[1964]: 21, 69-70) have also had a remarkable influence on him.

Barthes' book is one of those most often translated, along with Cobley, Jansz (1997).

\section{- Xiuhuang He's Introduction to Semiotics (1965)}

This book was evidently the first (and for many years the single original) introduction to semiotics in Chinese. Its main emphasis is on the semiotics of language. After a chapter on the general semiotic account of language and language function, it dwells on pragmatics (including cognitive aspects and functional errors), semantics (including the analysis of semantic errors, and translation), and syntactics (including the analysis of $\operatorname{logic}$ ), in this sequence.

\section{- Bense's Semiotik: Allgemeine Theorie der Zeichen [Semiotics: General Theory of Signs] (1967)}

This is a short but very dense and original introduction to Peircean semiotics. First, it gives an overview of Peirce's theory of signs (abstract semiotics), then moving on to the issues of ontology and epistemology of signs. Finally, Peirce's classification of ten sign types is applied to the signs of natural language as well as different types of language. The work is richly illustrated with comprehensive diagrams.

\section{- Eco's La struttura assente [The Absent Structure] (1968)}

In this book, Umberto Eco took a step further than Barthes by posing "a question about the nature of semiotic study ${ }^{10}$ and its meaning. In other words, the kind of study

10 In discriminating between semiotics and semiology Eco here follows the schema by Louis Hjelmslev, calling the general theory of communication phenomena 'semiology' and individual sign systems 'semiotics'. In a more recent edition (Eco 2002) he has added semiotics to the subtitle and substituted semiology by structuralism. 
in which all phenomena of culture are viewed as facts of communication, in which individual messages become organized, and understandable in relation to the code" (Eco 1998 [1968]: 27). This book, originally published in Italian, laid the foundation for the English-language A Theory of Semiotics published in 1976.

The Absent Structure is one of the main works on theory of semiotics that demonstrates its status as a science. Eco consciously dissociates semiotics from linguistics or cybernetics or logic and focuses on visual communication phenomena of culture such as architecture and fine arts. Using visual communication as an example, he shows that any act of communication is oversaturated with socially and historically conditioned codes and therefore depends on them. Eco debates the epistemology of structural models, questioning whether structure is an object of study or an operational model, and introduces works of Lévi-Strauss, Lacan, Derrida and others.

In addition to his philosophical interpretation of the main issues of semiology and semiotics, Eco dedicates a separate chapter to the basic terms of semiotics such as sign, symbol, code, meaning, communication process, etc.

According to Lange-Seidl (1986: 182), the German translation of this work under the title Einführung in die Semiotik (1972), "for many Austrians and West Germans [...] really was a first introduction to modern semiotics". As Jürgen Trabant (1972: 13) has mentioned in the translator's introduction to the German edition, the present version of the book is a completely revised version of the Italian edition, which has not been published in Italy in this form.

\section{- Vetrov's Semiotics and its Main Issues (1968)}

Vetrov's definition of semiotics reflects a common understanding of this discipline for Russian academic faculties as a general theory of signs and languages that makes semiotics an all-inclusive science. Vetrov points out that semiotics is not limited to the analysis of separate sign situations as is linguistics but, due to the broad definition of sign, it also covers non-verbal languages. In his view, semiotics must be a comparative study of signs and languages of various sign systems, from animals to cybernetic machines, and it must therefore be seen as a universal science that is methodologically applicable to other disciplines. Vetrov's introduction to semiotics is a comprehensive overview of main problems and keywords of semiotics.

\section{- Mounin's Introduction à la sémiologie [Introduction to semiology] (1970)}

In the introductory paragraph, Mounin declares that he is mostly interested in semiology as a research tool and that he is not concerned with the works of Peirce or Sebeok. Moreover, he does not give in-depth comments on animal communication although he mentions this field of studies in his overview. He compares several authors' papers in the field of semiology, commenting on how functional or non-functional these studies are as regards their applicability on various materials. The book is a collection 
of short studies in different fields (written in the 1950s and the 1960s) related to the topics of communication, signification, linguistic and non-linguistic systems, code and sign, literary (incl. science fiction) and theatrical studies. It also offers a critical introduction to the writings of Morris, Hjelmslev, Barthes, Lacan and Lévi-Strauss. The book does not provide a coherent definition of semiology; neither does it clearly explain the scope of its objects and research. In his short overviews, Mounin refers to the historical background, mentioning a number of influential predecessors of the semioticians discussed; thus the book requires some previous knowledge of semiotics to be thoroughly comprehended.

\section{- Stepanov's Semiotics (1971)}

Stepanov defines semiotics as a science about natural and social sign systems. His multidisciplinary approach to semiotics is reflected in the chapters dedicated to several areas of semiotics: biosemiotics, ethnosemiotics, linguistic, abstract, and general semiotics. Almost a half of the book is dedicated to an attempt to describe the laws of general semiotics - the syntactic, pragmatic, and semantic ones, respectively.

Stepanov's view of semiotics is mainly rooted in a convergence of linguistic and literary studies; he states that his book may be read even as a semiotic introduction to linguistics (Stepanov 1971: 3). The book stands out as one of the earliest works clearly formulating the role of biosemiotics as a part of general semiotics.

\section{- Guiraud's Sémiologie [Semiology] (1971)}

Guiraud's little book of a hundred pages lucidly introduces semiotics to a wide audience, although it sometimes appears as terse and dogmatic, eo ipso implying that the readers should already have acquired basic knowledge, so that they could decide by themselves whether a semiological analysis is sound. The author describes semiology as "the science which studies sign systems: languages, codes, sets of signals, etc." (Guiraud 1975: 1) and discusses the scope of this science, considering its three aspects: systems of communication, forms of social communication, and modes of communication based on the use of sign systems. The book is structured according to these three aspects in the chapters on social, aesthetic, technical and scientific codes. The author also poses the question as to where to locate other types of communication, such as that of animals (zoosemiotics), machines (cybernetics), or living cells (bionics), rhetorically, without going thoroughly into the problem, thus leaving it up to the reader to decide.

- Carontini's and Peraya's Le projet sémiotique: Eléments de sémiotique générale [The semiotic project: Elements of general semiotics] (1975)

The book introduces a frame of synthetic theoretical concepts together with many methodological problems. The central authors are those who further developed Saussure's theory (Barthes, Kristeva, Althusser); but also Peirce's and Morris's approaches 
are thoroughly described. The authors' intention has been to allow a confrontation between the authors of different major schools. Starting from Saussurean general linguistics, it ends with a discussion of text semiotics and semanalyse.

- Nöth’s Semiotik: Eine Einführung mit Beispielen für Reklameanalysen [Semiotics: An introduction with examples for the analysis of advertising] (1975)

Nöth's first introduction to semiotics was published in the series Anglistische Arbeitshefte within the framework of English studies (Anglistik). In line with this fact, all eleven advertisements analysed in this volume originate in the English language - most of them derive from the magazines Life and Time, but not all of them are of US or UK origin. The book explicitly presumes at least basic knowledge of linguistics from its reader. From linguistics, Nöth states, we can proceed to a general theory of signs. Treating both Peirce and Saussure, yet discussing the former more systematically than the latter, Nöth acknowledges that semiotics is a very heterogenous field, claiming, however, that many differences are but terminological ones. The author accepts arbitrariness as the organizing criterion of different types of signs, but argues that arbitrariness is best judged with reference to what he calls Generalisierungskraft. While there is no doubt that the generative capability of the symbol is beyond comparison, Nöth claims that the icon can generate more variations in meaning than the index, so that consequently the latter is to be regarded as the simplest of the aspects of the sign. In addition to Peirce and Saussure, we also find Eco, Morris, and Nöth's older colleague Walter Koch among the scholars most often referred to. The examples provided illustrate diverse semiotic functions and phenomena; all chapters include exercises or questions for discussion and suggestions for further reading.

\section{- Trabant's Elemente der Semiotik [Elements of Semiotics] (1976)}

The textbook focuses on introducing semiotics as a new discipline. Trabant begins by quoting various renowned scholars (Locke, Lambert, Hegel, Saussure, Morris and KlausBuhr) on what semiotics is. Philosophy and linguistics are seen as primary sources of semiotics, complemented by influences from cybernetic theory of information.

The first part of the work gives an overview of the foundations of the theory of signs (Saussure, Morris, information theory). The second part develops the notion of sign as action. Trabant is a proponent of developing semiotics based on the theory of action, which could also be read as a critique of the positions on semiotics cited in the first part of the work. Trabant uses speech act theory, Wittgenstein's approach and hermeneutics to formulate the basis of his theory. A semiotic approach, as he says, should not be based on information theory's concept of communication, but on communication as action. 


\section{- Eco's A Theory of Semiotics (1976)}

First published in Italian as Trattato di semiotica generale (1975), this English edition remained one of most important and influential books on general semiotics for a long time. Several of its ideas were published in Eco's earlier book La struttura assente (1968) and its revised authorized version in German (Eco 1972).

Eco focuses on two major issues of the theory of sign: communication and signification. As he states, "the aim of this book is to explore the theoretical possibility and the social function of a unified approach to every phenomenon of signification and/or communication" (Eco 1976: 3). Up to today, A Theory of Semiotics is one of the few books which provides an integrated general theory of semiotics. Separate chapters have been dedicated to the theory of codes and the theory of sign production (including the critique of iconism). ${ }^{11}$ For an untrained reader this is not an easy reading. The most often quoted passage of the book defines semiotics as a theory of lying.

\subsection{Structuralism in transformation - the late 1970 s and $1980 \mathrm{~s}$}

In this period, the geography of published introductions increased considerably. These years also brought into existence the first English-language original textbooks in the field (Thomas 1973; Eco 1976; Hawkes 1977; Scholes 1982; Deely 1982, 1990; Silverman 1983; Berger 1984; Sless 1986; Clarke 1987; Solomon 1988; Tejera 1988), alongside with the first translations into English (Guiraud 1975, following Barthes 1967, 1968).

\section{- Hawkes' Structuralism and Semiotics (1977, 2nd ed. 2003)}

This book was the first volume published in the 'New Accents' book series of Routledge of which Hawkes himself is editor. Despite the critical and sometimes fierce responses (mainly because of its approach to the intellectual history of structuralism and semiotics) the book has received since its first publication, it remains one of the most influential introductionary texts written on the general topics of structuralism and semiotics. In spite of its ambitious title, the whole scope of the book is reserved to a short, simple yet comprehensive, easy-to-grasp introduction to the history of intellectual movements involved in structuralist thought (beginning with forerunners of "structuralism" Vico, Piaget, Sapir, Whorf, proceeding with Saussure and Lévi-Strauss, and concluding

11 Eco himself has mentioned regarding this book: "Looking back [...] at Theory of Semiotics, I discovered - that was evident - that it has two parts. The first part was not an achievement, I was simply trying to put together what already existed and to tell it better. The second part, the modes of sign production, was practically not studied by anybody. I was convinced I had written something interesting. Now recently in the last six or seven years some of my younger students started to write on those aspects, saying that they are the most interesting ones in the book" (from U. Eco's interview to K. Kull and E. Velmezova, Jan. 15, 2012). 
with the "New Criticism"). The author is basically concerned with the application of structuralist methods to "critical" literary studies, as well as the the impact structuralist thought has had on literary study. The book includes a short introduction to the basic concepts of semiotics, with comments by the author. Interestingly enough, Hawkes' book does not include a clear explanation on how the structuralist way of thinking relates to semiotics, except for one passage in the book that implies that semiotics and structuralism overlap, with semiotics being a field of sign studies and structuralism a method of analysis often used in semiotics.

\section{- Pelc's Prolegomena to Semiotics (1982)}

This book by Jerzy Pelc, one of the most important Polish theorists in the humanities, is dedicated to the analysis of sign and signification process, defining the main subject of theoretical and applied semiotics. Pelc discusses the subject of semiotics itself by studying the triad "semiotics-semiology-semantics", asking whether these are synonyms or three independent fields, three scientific traditions or individual approaches to one subject. The author's explanation starts from a historical review of existing traditions and ends with an overview of the current state of human sciences in Poland, aiming to reveal the essence of common misunderstandings in the use of the three terms. Nevertheless, Pelc follows the terminology of "Slavic" tradition and even creates his own concepts by offering five separate terms: semioty $k a_{w}$ - semiotics which separately studies processes of signification, syntactics, semantics and pragmatics or combination of them; semiotyk $a_{N}$ - theory or discipline, which studies derivatives of semiotyka, meta-semiotics; semiotyk $a_{t}$ - theoretical semiotics; semioty $k a_{m}$ - methodological semiotics; semiotyka - applied semiotics.

Meanwhile, the author notes the need to introduce semiotics to a wide audience in order to assure its steady growth and value in the future. The book is easy to read, contains numerous clear explanations and examples and gives quite a broad overview of the main issues of semiotics.

\section{- Scholes' Semiotics and Interpretation (1982)}

Scholes' book could rightfully have the subtitle "Introduction to literary semiotics", but we have included it in our review as an excellent example of a user-friendly textbook on applying semiotics in the humanities. The author is concerned about the pedagogical aspects of his work and stresses the importance of the students' own interpretation: "the student's productivity is the culmination of the pedagogical process" (Scholes 1982: 4-5). To achieve this purpose, the student must be exposed to models of interpretive texts. Scholes offers a useful and inspirational set of such models based on the ideas of Jakobson, Barthes, Riffaterre, Lotman, Todorov, Genette and other scholars. The addendum of this valuable book consists of a little glossary and a commented bibliography. 
It should also be emphasized that Robert Scholes from the Department of English, together with Thomas Winner from the Department of Slavic Languages in Brown University (USA), led the first American study programme in semiotics between 1974 and 1987 until the establishment of the Center for Modern Culture and Media (Mitchell 1993).

- Santaella's O que é semiótica? [What is semiotics?] (1983)

Lúcia Santaella's $O$ que é semiótica? has been reprinted numerous times since it first appeared in Brazil in 1983 and is the best-selling book among her many publications ${ }^{12}$. Despite its centrality in the Brazilian context, Santaella's introduction has not been translated to any other languages. Published in a book series called "The First Steps", it is meant to be a fairly brief introduction. It is written in an accessible style and makes frequent use of everyday examples. The reach of semiotics, says Santaella, is vast, but not infinite. Relying on the legacy of Peirce, who is described as "a Leonardo of the modern sciences", is the dominant feature of this introduction to semiotics. His scheme for the sign, and his matrix for the sciences, is emphasized. Semiotics is treated in its relation to phenomenology, psychology etc. Saussure, however, is discussed only at the end of the book, in the section entitled "Other sources and pathways" - along with "The Soviet sources". Santaella stresses that the convergence of three sources of semiotics in the creation of one unified field should not make us forget their distinct differences.

\section{- Silverman's The Subject of Semiotics (1983)}

This book is not really an introduction but is intended as a methodological guide which claims the centrality of psychoanalysis to semiotics. The work covers the ideas of Saussure, Peirce, Barthes, Derrida and Benveniste, but the main heroes for the author are Freud and Lacan. Her point is that the human subject is the subject of central importance to semiotics. The book includes a post-structuralist (and feminist) introduction to the analysis of film and literature as studied in connection with viewers and readers. Thus, it represents an original approach for advanced-level students.

\section{- Berger's Signs in Contemporary Culture (1984)}

This introduction to semiotics follows a playful approach, being illustrated with drawings (based on punning: con-tent, con-science, con-cussion etc.) by the author, and also clearly understandable explanations and excerpts from well-known texts (Shakespeare's plays, Defoe's Robinson Crusoe's adventures, Charlie Chaplin's movies, Andy Warhol's soup cans etc.). Berger's study does not aim systematicity; neither does it follow a chronological order nor lay an emphasis on either Saussurean or Peircean semiotics (if so, then it rather prefers the latter), but it still covers the main concepts

12 It has sold around 150,000 copies altogether (Winfried Nöth, personal communication). 
of semiotics - signs, codes, denotation, connotation, meaning. Without giving an overview of the historical or theoretical developments in the field, it helps newcomers to semiotics analyse the surrounding cultural artefacts as signs (e.g., signs of identity, signs of marketing, signs that lie). Berger concentrates only on the signs of human beings, without mentioning non-human animal signs or biosemiosis.

\section{- Sless' In Search of Semiotics (1986)}

David Sless seems to be best known for his claim that "semiotics is far too important an enterprise to be left to semioticians" (Sless 1986: 1) which is the opening sentence of the book. Indeed, one of the stated aims of his book is to make semiotics more accessible to a general audience by discarding obscure jargon. The book is easy to read, with each chapter concentrating on one topic summarized at the end of the chapter. All in all, it is a short and clear presentation of Sless's conception of semiotics. For the author, semiotics is first and foremost the study of communication and understanding. Within communication, there are two kinds of semiosis: one within the author/text relation and the other within the reader/text relation; researchers into semiotics must occupy one of these positions. Much of his book is devoted to the analysis of the different positions that can be taken by participants in communication. In this sense, as Sless claims, semiotics is not a science, as communication cannot be studied from a neutral position (Sless 1986: 38). Another problem that Sless explores is the question of meaning, which he defines as "the end product of semiosis" (Sless 1986: 91). The last two chapters of the book are dedicated to semiotic research and the founders of semiotics. While some aspects of the book could be considered outdated, it is noteworthy in its goal to guide the reader away from semioticians and towards semiotics.

\section{- Clarke’s Principles of Semiotic (1987)}

This is a brief introduction to semiotics as a discipline on language and logic, written in an enjoyably lucid style. In this sense, it is a good coursebook on the Peircean school of semiotics from the point of view of a philosopher of language. Clarke starts his history of semiotics from the antiquity, concluding that semiotics was mostly applied in the field of medicine where a symptom stands for a disease. He discusses the views of Aristotle, the Stoics and the Epicureans on linguistic semiotics, paying much attention to Sextus Empiricus. Mediaeval authorities noted include St. Augustine and William of Ockham. From the field of communication theory, a treatment of H. P. Grice and the theory of speech acts is included. In the final chapter, entitled "Language", Quine, Frege and Kripke are covered. The textbook is accompanied by a reader featuring excerpts of texts from the authorities cited or otherwise useful in the same context (Clarke 1990). 
- Heradstveit's and Bjørgo's Politisk kommunikasjon: Introduksjon til semiotikk og retorikk [Political communication: Introduction to semiotics and rhetorics] (1987, 1992)

This book, written by two scholars of political science, is the only Norwegian introductory textbook on semiotics and has mostly been used in other disciplines, including media studies, political science, and sociology. The political issues included are illustrated with examples from the Arab-Israeli conflict. A central motif for the authors is the argument that semiotic theory can fruitfully be applied in analysing political language and media-related political discourse in particular. Nevertheless, the structure of this book is theoretical and concept-oriented in semiotic terms, its three parts treating the sign, the text, and the context as the general framework (one interesting discussion is the inquiry into the potential radicality of metaphor, and the conservative bias of metonymy). Rhetorics is presented as a subfield of semiotics Aristotle is thus adopted as a semiotician ante litteram - and notions from philosophy of language appear side by side with notions taken from Peirce, Saussure and various post-modern thinkers. As a result, the approach to semiotic matters appears to be broad and pragmatic, but language - or, how social/societal events can be represented in language - is for the most part what it is all about. The authors suggest analysing politics in general as a process of communication and make no exception for terrorism.

\section{- Tejera's Semiotics from Peirce to Barthes: A Conceptual Introduction to the Study of} Communication, Interpretation and Expression (1988)

Victorino Tejera claims his introduction to be addressed to relatively advanced readers - "communication theorists, hermeneuticists, and culture-analysts, as well as to students of philosophy and literature looking for a basic, but well-developed, introduction to semiotics" (Tejera 1988: ix). The book's advanced introduction presented as an account of history of semiotics, especially that of pragmati(ci)sm and structuralism, provides rather a thorough survey of the development of a set of ideas as definitive categories of semiotics. With the main emphasis on Peirce who is also cited extensively, Tejera puts much effort into uncovering the dialectics of the development of Peirce's ideas. In connection to these, Mead's theory of meaning as well as Dewey and Randall are discussed. Via these three and Habermas, Tejera establishes the somewhat surprising connection between Peirce's theoretically biased semiotics to Barthes and literary analysis. In the general context of semiotics textbooks and introductions, Tejera's clearly stands out by discussing the pragmatist context of Peirce and semiotics following that context (e.g., a part of sociosemiotics), while he arrives at semiotics of literature. 
- Tarasti’s Johdatusta semiotiikkaan: Esseitä taiteen ja kulttuurin merkkijärjestelmistä [Introduction to semiotics: Essays on the sign systems of art and culture] (1990)

The author's stated intention was to write an introductory work on semiotics that would not require preliminary knowledge in the field. As such, it is a useful text and has been used as a coursebook by Finnish university students in introductory courses to semiotics. The volume includes a concise 40-page overview of three approaches: (1) Saussurean, Prague School and Russian formalist semiotics; (2) Peircean semiotics; and (3) French structuralism. The abundance of interesting examples of the use of semiotic theory, especially from the field of music - Tarasti being a semiotician of music - is noteworthy. Lévi-Strauss is often referred to as an important authority throughout the treatment, as are Barthes, Lotman and Eco.

The rest of the book comprises essays on "sign systems of art and culture", written and published by the author over 15 years. On the theoretical side, these include a treatment of Greimas's semiotics that draws parallels with Lotman, and several essays on structuralism and the work of Lévi-Strauss. The final part of the book has a more applied edge, making a call for landscape semiotics and involving treatments of the opera, Finnish and Brazilian cultures.

\section{- Deely's Basics of Semiotics (1990)}

This book has appeared in several (including bilingual, Deely 2005) editions and translations, and replaces Deely's earlier Introducing Semiotic (Deely 1982). The underlying theme of Deely's introduction is the historical development of semiotics as a field (or doctrine) of inquiry from Augustine via Poinsot and John Locke to Peirce and Sebeok. It also observes how the more-or-less semiotically minded thinkers relate to philosophers that were less so, Descartes and Kant included. Deely's conception of the sign entails that it mediates between physical reality and any experience of reality (as well as between reality as it exists in physical terms and reality as it comes into being by way of influence from the future). The fifth edition, published in 2009 by Tartu University Press, contains five new chapters into which he incorporates his by then developed thought about the human being as a semiotic animal (rather than a rational animal pace Aristotle or res cogitans, i.e. a thinking thing pace Descartes). A crucial distinction is between objects as sometimes mind-independent and sometimes not - a distinction Deely claims only the semiotic animal is capable of drawing. Deely sets out on a familiar terrain, with a depiction of literary semiosis, and further covers zoösemiosis (contrasted with anthroposemiosis), phytosemiosis and physiosemiosis. The more general exposition includes forays into the status of semiotics as an academic field, its subject matter (defined very broadly), history, and medium - the signs. The overall impression is that his historical account ends in the future, not in the present. John Deely is a prophet of a time to come and few, if anyone, have with such vigour and faith defended the thesis that semiotics matters not only to semioticians, but to science 
and thinking as such. Taken as an introduction, Basics is a rather elaborate theoretical discussion, without including textbook-like features.

\subsection{Specialization and combined approaches: the $1990 \mathrm{~s}$}

Together with the publication of remarkably high-quality textbooks (e.g., Sebeok 1994; Johansen, Larsen 1994), this period is also characterized by the publication of popular introductions for a much wider audience (Cobley, Jansz 1997; Kreidlin, Krongauz 1997).

- Álvarez Sanagustín's (et al.) Introducción a la semiótica: actas del curso de "Introducción a la Semiótica" [Introduction to semiotics: Minutes from the course "Introduction to Semiotics"] (1992)

This Spanish introduction is a collection of essays, originally study materials for an introductory course in semiotics. This co-authored work is heterogeneous in its subject areas and approaches, but as a practical teaching textbook it has the aim to include various approaches and to introduce the 'multidisciplinary landscape of semiotics'. It includes linguistic and literary traditions (e.g. Jakobson, Eco, Lotman), semiotics of theatre and poetics, and an introduction to Peircean semiotics, using examples from Latin America.

- R. and C. Marty's 99 réponses sur la sémiotique [99 answers on semiotics] (1992) This small brochure is an interesting example of a French series of books consisting of 99 questions and short answers that cover the most basic facts of a field. The questions start with defining semiotics, the difference between semiotics and semiology, and the object of semiotics. The major part of the questions is devoted to Peirce's theory: his sign categories and classification, abductive argumentation, notions of text and narrator. Other theoreticians with whom Peirce's ideas are compared include Propp, Saussure, Barthes, Greimas, Hjelmslev, Prieto, and Ubersfeld (as semiotics of theatre is also touched upon). More extensive attention is also paid to the semiotics of proper names and semiotics of education.

\section{- Leeds-Hurwitz's Semiotics and Communication: Signs, Codes, Cultures (1993)}

This is an example of a textbook in semiotics written for students in a certain field - in this case, communication studies. This necessitates that the book is not as wide in scope as some other introductions to semiotics, covering only those areas that are important from the point of view of studying human communication. It introduces semiotics as a tool for communication studies, which helps to "close the gap between what we are able to do as social actors and what we are able to describe as social analysts [...]. It seems to me that some of the words needed [for explaining social behavior] are to be found 
within semiotics" (Leeds-Hurwitz 1993: xii). Another characteristic of the book is its focus on practical analysis of human behaviour, as opposed to pure theorizing, which Leeds-Hurwitz finds the majority of American semioticians spend too much time on (Leeds-Hurwitz 1993: 12).

The book is divided into three major parts. The first part introduces the founders of the discipline, Peirce and Saussure, and "key semiotic concepts", namely those of signs, the most important kind of which from the perspective of communication studies are symbols (communication, as understood in this book, uses symbols); and codes, with social codes getting the most attention. In the second part of the book, Leeds-Hurwitz demonstrates how these concepts can be used in describing social behaviour, analysing three examples of particular social codes: food, clothing, and objects. The third part of the book introduces the concept of culture in order to analyse the interrelations of different codes.

\section{- Sebeok's Signs: An Introduction to Semiotics (1994; 2nd ed. 2001)}

Thomas A. Sebeok's introduction differs from the rest mainly because Sebeok pays less attention to the structuralist tradition, concentrating upon the study of the sign and building his approach upon the all-embracing concept of semiosis instead. He develops semiotics which is biologically informed, expanding semiosis to all 'living things' including all five kingdoms and their component parts. Sebeok delineates a typology of six species of signs as "the types of signs most regularly identified and commonly employed by semioticians" (Sebeok 2001: 39) - signal, symptom, icon, index, symbol and name - discussing their structure and functioning. He looks back to the medical origin of semiotics through the concept of symptom, stating that "their denotata are generally different for the addresser (i.e., the patient [...]) than for the addressee (i.e., the physician)" (Sebeok 1994: 24; 2001: 47) and that requires an interpreter. Looking at fundamental forms of semiosis, Sebeok finds that while symbol is primary within the human approach, iconicity constitutes a central principle of semiosic organization and patterning in living nature. He argues that non-verbal modes of knowing lie at the foundation of being, being more widespread than language, a unique ability of human communication, just like fetish signs are a unique illustration of human semiosis.

- Johansen's and Larsen's Signs in Use: An Introduction to Semiotics (1994, English ed. 2002)

Two Danish professors of comparative literature have authored a balanced approach to semiotics in which the concepts of discourse and narrative occupy a prominent place. Vivid illustrations and examples from different walks of life render the subject comprehensible, yet not oversimplified. A professionally compiled glossary and biographical sketches of persons covered in the book provide a useful supplement. 
The title of the textbook "Signs in use" is, according to the authors, a "slight adaptation of a Peirce quotation, 'signs are only signs in actu"' (Johansen, Larsen 2002: 114). Although the authors represent the Peircean (functional/dynamic) view of semiotics, they have managed to give a panoramic picture of semiotics as a discipline, which also incorporates the European tradition. Their successful strategy for overcoming the contradiction between the two main tendencies of semiotics is finding the dynamic aspects in the structuralists' works.

The book is divided into seven chapters, where the reader is guided from the notions of the code and the sign through text and discourse to culture and its semiotic analysis.

The notion of semiotic threshold is not present in the book but at the very beginning of the first chapter the authors admit that semiotic competence is not the privilege of humans and give examples from the animal kingdom. The main focus of the book nevertheless is on the semiotics of text. Discourse analysis and its various methods, as well as modern narratology, are discussed quite thoroughly. Text is understood as semiosis rather than as a complex structure.

- Danesi's Messages and Meanings: An Introduction to Semiotics (1994, 2nd ed. 1998, 3rd. ed. 2004)

Marcel Danesi has taught a very popular semiotics course at the University of Toronto, and this textbook reflects his course. Danesi has been constantly developing his course and has published the updated versions regularly. The second edition (1998) is titled Sign, Thought and Culture: A Basic Course in Semiotics, and the third (2004) Messages, Signs and Meanings: A Basic Textbook in Semiotics and Communication Theory. A completely reworked version for the general reader appeared in 2007 (see Danesi 2007). The author states that the purpose of the book is to provide students with a textbook "[...] that would introduce the technical, and often abstruse, subject matter of this fascinating field in a practical way, with plenty of applications of semiotic techniques to contemporary social discourses and lifestyle behaviours" (Danesi 1998: 5). Trying to avoid complicated terminology he wants to lead his readers to independent semiotic discoveries by using what each of them already knows intuitively. He defines semiotics as a study of the capacity to create and use signs for thinking and communication. The emphasis in the book is on media and mass communication.

\section{- Kim's Caged in Our Own Signs: A Book About Semiotics (1994, English ed. 1996)}

Kim's objective is to introduce the basic concepts of semiotics and semiotic methodology for non-specialists in a readable way in order for them to be able to apply this knowledge to their everyday experiences. The first chapters introduce the basic constructs and frameworks for semiotic thinking (the structure of signs, production of meaning, construction of reality, codes and codification). In the second part of the book the 
author "intends to contemplate with the reader on the modes, and their meanings, of mutual interactions between human beings and their semiotic environments in the so-called postmodern era" (Kim 1996: xiii). Providing numerous examples throughout the book that link theories to real-life situations Kim deals with symbolic systems constituting text: image, metaphor, narrative, myth, ideology. The main emphasis of this introduction is on the semiotics of communication, the main goal of the book is not only to explain semiotics and teach the readers to create signs of their own, but to help us to understand the surrounding world full of signs.

Kim (1996: 14) also writes: "Peirce's model and Saussure's model are only slightly different. [...] The object (i.e., referent) in Peirce's model pertains to the signifier in Saussure's model, and the interpretant (reference) in Peirce's model pertains to the signified in Saussure's model. [...] I resort mainly to the Saussurean model in [...] this book".

- Keller's Zeichentheorie: Zu einer Theorie semiotischen Wissens [Theory of Signs: About Theory of Semiotic Knowledge] (1995)

Although concentrating primarily on language, the book is diverse both in its structure and content. From exemplifying the semiotics of everyday life with the analysis of German middle-class apartments, the author moves on to Plato's, Aristotle's, Frege's and Wittgenstein's concepts of sign, addressing thereafter more specific questions of semantics, cognition, sign formation, the dynamics of symbols, icons and indexes and finally concluding with the topics of language change. Keller makes a distinction between the instrumental sign concepts of Plato and Wittgenstein, and the representational approach of Aristotle and Frege; the author himself departs from the instrumental approach. Keller's intention has been to write a book which is not meant for an academic audience only, thus avoiding too specific terminology or complicated structure. In this respect, the book attains its goal and is a good example of how clarity need not mean being simplistic. Traditional semiotic theories are combined with modern trends in semantics, metaphor and symbol theories, while all this is cast into the author's own original framework.

- Nöth's Panorama da semiótica: De Platão a Peirce [Panorama of Semiotics: From Plato to Peirce] $(1995,2003)$

A title somewhat related to Deely's $(1990,2001)$ book, yet more modest. This introductory work consists of two volumes, with the more extensive second volume A semiótica no século XX Semiotics in the 20th Century having appeared in 2003. The fourth edition of the first volume appeared in the same year. 
- Klinkenberg's Précis de sémiotique générale [Basis of general semiotics] (1996)

A thorough textbook, well usable in university courses. The author, a member of Groupe $\mu$ from Belgium, follows the structuralist tradition and pays considerable attention to rhetoric and visual semiotics. The book is structured according to the main concepts discussed. The chapters cover communication, signification, semiotic description, families of signs, and, remarkably, code plurality. Peircean concepts are virtually not used in this book. History of semiotics is not described and very few names appear in the text which is supplied with a good selection of suggested reading.

\section{- Cobley's Semiotics for Beginners (1997)}

The introduction to semiotics written by Paul Cobley and illustrated by Litza Jansz has become the most translated semiotics book in the world, having reached at least ten languages. Since 1999 its reprintings in English are titled Introducing Semiotics due to the new name of the whole series of "introducingbooks" into which it belongs. The 2010 edition uses the title Introducing Semiotics: A Graphic Guide.

In his preface to the Estonian translation, Cobley (2002: 1-2) states that his motivation for writing the introductory volume came from the very limited understanding of semiotics in the United Kingdom. In the 1970s, semiotics was seen as an ad hoc or intuitive method applied solely to the study of literature, while in the British universities of the 1980s and 1990s, semiotics was known only through the works of Roland Barthes, some of which were already outdated.

In order to fill the void between the actual scope of the study of semiotics and the limited British view of the field in the 1990s, which saw semiotics as a product of the Paris School structuralist and post-structuralist approach, Cobley made it his goal to provide an introduction of "the tradition of semiotics in a more global manner" (Cobley 2002).

The book begins with a short overview of the prehistory of semiotics, including ancient philosophy and particularly Plato and Aristotle; thereafter, it discusses Medieval approaches to signs (St. Augustine, William of Ockham) and moves on to the more recent classics of semiotics who constitute the main focus of the book. Cobley introduces the concepts of Saussure, Peirce, Morris, Jakobson, Hjelmslev, Benveniste, Lévi-Strauss, Barthes, Greimas, Derrida, Uexküll, Sebeok, Lotman, Eco and several others who contributed to the study of semiotics throughout the 19th and 20th centuries.

The broad historical and geographical scope of the introductory work comes at a price: the readers should not expect to find in-depth explanations, as each person, school and concept is discussed only in as much detail as is necessary for a brief first introduction.

The illustrations by Litza Jansz deserve a special mention: the humorous yet truthful portraits of semioticians are complemented by diagrams providing visual support to the 
theories. Due to the large number of illustrations, the book has even been compared to a comic book.

- Kreidlin's and Krongauz's Semiotics, or an Alphabet Book of Communication (1997, 2nd ed. 2004, 4th ed. 2007)

This Russian-language introduction meant for semiotics classes in primary schools, which is probably the first of its kind in the world, deserves special mentioning. The very existence of this textbook is a strong statement itself and it is well developed and thoroughly and thougthfully presented to serve as a very basic, and at the same time essential, introductory textbook on semiotics. It provides a broad vision of what is semiotics - a science, as it says in the author's foreword, that has been invented and given its name by Peirce. The book, however, as the authors claim, is less about the science than about signs and sign systems, which themselves are languages of human communication. The notion of communication is developed to encompass an extremely wide range of human interaction and ways of life, including trade. It also offers a good outlook on communication theory. The book is rich in examples of different sign systems and perception phenomena, being simulataneously encyclopaedic and childishly simple. Even though it lacks some of the "deeper" and more theoretical topics raised, e.g., by Chandler's Semiotics for Beginners, it should still be noted that even without numerous and lengthy quotations, it can be the latter's rival to be reckoned with. Thus, Kreidlin's and Krongauz's book contains an excellent and easy-to-follow introduction to kinds and types of signs, which is a staple topic of virtually each introductory textbook, and in this particular case it has been executed elegantly before proceeding to the no less concise chapters on sign systems, paradigms, syntagms and signs in culture.

- Chandler's Semiotics: The Basics (1st Spanish translation from English online ed. 1998; 1st English ed. 2002, 2nd ed. 2007)

During many years David Chandler has been developing this textbook to accompany his lectures on an internet site ${ }^{13}$ where one could observe the evolution of the text. Initially, its title was Semiotics for Beginners, but the appearance of Cobley and Jansz book of the same title (Cobley, Jansz 1997) made Chandler modify the title of the web version of his book into Semiotics for Absolute Beginners, and later Semiotics: The Basics was used for the print version. Indeed, the presentation of the subject does make it intelligible also for absolute beginners, and it became also one of the best-known introductions to semiotics of the present time.

13 Its address: http://visual-memory.co.uk/daniel/Documents/S4B/. The online version is still being updated from time to time. It is differently structured and includes somewhat more visual illustrations. 
In the introduction the author says that the book grew out of his need to explain to his students what semiotics was. The approaches existing in 1994 were, in his words, all obscure and dull, whereas semiotics itself was nothing beyond comprehension. The book exclusively deals with human semiosis, leaving aside biosemiotics, computer semiotics and ecological semiotics. Neither does it discuss the semiotics of music and architecture. The book is targeted at Europe, its focus is explicitly set on the structuralist path and it also bears strong influence of media semiotics. Nevertheless, this does not mean that there would be no brief overview of, e.g., the Peircean sign. According to Chandler, the field of semiotics does not belong between the walls of academia exclusively, but could serve as a very useful "tool" in everyone's everyday life.

The text is well structured and moves step by step from the models of sign via the ways of analysing structures to intertextual relations. The author has also added a couple of reflexive subparagraphs on the reasons of studying semiotics at all and on the limitations and strengths of the semiotic ways of perceiving the world. The book is supplied with a glossary and a list of suggested further reading.

- Danesi's Of Cigarettes, High Heels, and Other Interesting Things: An Introduction to Semiotics (1999)

This is an excellent example of popularizing semiotics. The book introduces several semiotic concepts, using attractive examples from everyday life of humans. It describes scenes from the life of a young American couple, as if videotaped, and stopping the tape regularly, while introducing signifier, signified, sign, signification, language, metaphor, the meanings of space, the artistic nature of human species, media, etc. Danesi has proposed a delightful presentation of semiotics, one of very few really popular introductions.

\section{- Schönrich's Semiotik: Zur Einführung [Semiotics: For Introduction] (1999)}

In its major part, the book is a theoretical elaboration of Peirce's classification of signs and the principles of sign processes. Its subtitle as "an introduction" is somewhat misguiding, as the book rather is an in-depth analysis of triadic processes of language and thinking. Although the author starts with a brief history of semiotics (from Hippocrates to Peirce), the rest of the book deals with various logical combinations of the object-sign-meaning entity. The author finds that so far semioticians have not been able to agree even on the status of their own discipline, which is due to the lack of a common understanding of the basic notions that describe semiotic processes. With his "Semiometrie", the author tries to provide such a common ground by introducing some basic formulas for semiotic acts. 
- Veivo's and Huttunen's Semiotiikka: merkeistä mieleen ja kulttuuriin [Semiotics: From Sign to Mind and Culture] (1999)

This textbook is presented as "the first systematic Finnish textbook in semiotics" (Veivo, Huttunen 1999: back cover). It combines a general introduction and definitions, parts on signs (including chapters on structuralism, post-structuralism and the pragmatic approach), sign work, communication, cultural semiotics and short history of semiotics. The section on signs consists of a chapter on structuralism that exclusively presents the (linguistic-semiologic) ideas of Saussure; the following chapter on post-structuralism (that is conceptualized as the strive to involve the context outside the sign) introduces the approaches of Lacan, Kristeva and Derrida. The third chapter is devoted to an introduction to Peirce's concepts. The textbook's merit lies in the inclusion of a broad range of examples from semiotics of language to semiotics of literature and texts. The style of Huttunen's chapter on semiotics of culture that discusses the Tartu-Moscow School clearly differs from Veivo's. A short 22-page history of semiotics that concludes the book includes João Poinsot, John Locke, and Etienne B. de Condillac as forerunners of modern semiotics.

\section{- Lidov's Elements of Semiotics (1999)}

Lidov's book is a good theoretical study on general semiotics. The text is arranged to be useful to the novice, presenting the theory of semiotics in the context of classic sources. David Lidov understands semiotics as a comparative perspective of the artifacts of conscious life. This makes him also pay attention to the possibilities of the existence of unconscious signs. The authors he is using include, e.g., Hjelmslev, Martinet, Goodman. He speaks about structuralism as a supplement to pragmatism. Among other, he says: "I mention Greimasian theory because of its influence and suggestiveness, but I have not been able to discover any grounds for believing it" (Lidov 1999: 137). Lidov's background in the theory of music gives advantage to represent different theories and models in clear and playful manner.

- Merrell's Signs for Everybody, or, Chaos, Quandaries, and Communication (2000) While this book purports to be about "semiotics for everybody", one could argue that Signs for Everybody is not really an introduction to semiotics but an introduction to Peircean semiotics. Still, Peirce's person plays a marginal role here compared to his philosophy. In fact, Merrell has chosen to avoid the history of semiotics altogether and present instead an explanation of the basic semiotic categories. Starting from a discussion of Peirce's concept of the sign, he moves on to the categories of firstness, secondness and thirdness, the different types of signs, and the action of signs. After this, Merrell proceeds to the second major theme of the book: the criticism of binarism. For this purpose, he adopts terms and concepts borrowed from mathematics and quantum physics, attempting to show that life and semiosis cannot be described in purely linear and binary terms. 


\subsection{The search goes on: the $2000 \mathrm{~s}$}

The number of original introductory books on semiotics that have appeared in the last decade is relatively high compared to the previous decades, which may indicate the growth of the field. In English, original books have appeared authored by Chandler (2002), Crow (2003), Hall (2007), Danesi (2007) (these four lay a strong emphasis on applied semiotics and visual examples, and target non-specialist audience); in Italian by Volli (2000), Calabrese (2001), Pozzato (2001), Gensini (2002), Magli (2004), Traini (2006); in Russian by Grinev (2000), Ageev (2002), Mechkovskaya (2004), Fedorova (2004), Solomonik (2004), Barulin (2002), Proskurin (2005), Nikitina (2006), Pocheptsov (2009); in Hungarian by Voigt (2008); in Czech by Doubravová (2002), Černý and Holeš (2004); in Danish by Kjørup (2002), in Turkish by Rifat (2009).

\section{- Volli's Manuale di semiotica [Manual of semiotics] (2000)}

The textbook by Ugo Volli (2000; 2006; German translation 2002) is closely related to the author's special fields of interest, mainly media semiotics, communication studies and applied semiotics. The main notions analysed are communication, sign, and structure; one of the most important theoretical backgrounds is the school of Greimas and his concept of the semiotic square. A large part of the book is devoted to an introduction to textual semiotics and its terminology (narration, focalization, actantial models, modalities, enunciation, etc.), mostly based on the writings of Lotman, Uspenskij, Tomashevski, Eco, Genette, Propp, etc. One of the fields covered is also the "social life of texts" in culture, semiosphere, mode, myths, political sphere, public communication, TV, etc. Volli supports a broad understanding of the term 'text', analysing languages of arts of cinema, theatre, music, comic books. The last chapter is concerned with the debate on post-structuralism and British Cultural Studies against the background of semiotics. Here, the author expounds his view with regard to the main similarities and differences between semiotics and other approaches that view text, culture and discourse as fundamental concepts. Most of the chapters and subsections end with tips for further reading and references to other, often Italian, theoreticians who have discussed the terminology.

\section{- Pozzato's Semiotica del testo [Semiotics of the text] (2001)}

The textbook by Maria Pia Pozzato is a study of the concept of text; in each chapter, a prominent canonical writer's work is introduced. The major part is dedicated to the model of Propp (actantial analysis) and its reformulations and developments in the theories of Greimas (narrative grammar), whose works are also compared to the mythological analysis of Lévi-Strauss. From the works of Eco, the notions discussed are 'model reader' and the 'limits of interpretation'; this is followed by an analysis of Thomas Mann's book Buddenbrooks. The chapter on literary semiotics is devoted to Jacques 
Geninasca, and the chapter on artistic text engages with the works of Juri Lotman and the Tartu-Moscow School. The other two important fields are sociosemiotics, and media and brand semiotics (including a separate study of semiotics and television), based on the works of Eric Landowski and Jean-Marie Floch. The textbook offers several exemplary analysis of brands (kitchen cleaning products) and commercials (perfumes), from the aesthetic, economic and consumer aspects adding up to an interdisciplinary analysis. Among other things, Pozzato also makes the interesting distinction between figurative and plastic semiotics.

- Roventa-Frumusani's and Gaudreault's Pour connaitre la science des Signes: Introduction à la sémiotique [Knowing the Science of Signs. Introduction to Semiotics] (2001)

This introduction is meant primarily for students of communication and other students of therein, the humanities. In a chapter titled "Love and other subjects" both Saussurean and Peircean semiotics are described, with an emphasis on their development. The utterance is analysed with the help of Jakobson's, Searle's, and Adam's theories, synthesising these into one. In the analysis of narrative behaviour, the approaches of Greimas, Bremond and Wiener are brought together. Propp's functions are related to Maslow's concept of needs. Theatre semiotics is given a separate chapter. Each chapter is supplied with exercises for the student, followed by thorough answers. The book includes glossary of terms.

- Bankov's Семиотични тетрадки [Semiotic Notebooks] (Part I, 2001; Part II, 2004) The first part of Kristian Bankov's book is a synopsis of introductory lectures on semiotics delivered by the author at New Bulgarian University. It is structured as an overview of the history of semiotics, introducing the work of Saussure, Peirce, Propp, Greimas, Barthes, Eco, Lotman. Essential concepts of semiotics, such as sign and its types, semiology, langue/parole, semiosphere, semiosis, communication, etc., are introduced chapter by chapter. Bankov defines semiotics as a theory of interpretation, rather than the conventional 'science of signs.' The book deals with semiotics of culture and sociosemiotics; the fields of biosemiotics, ecosemiotics, visual semiotics are left aside. He also describes the so-called 'Semiotic Cold War' between the French structuralist approach and American Peircean semiotics in the past decades and mentions that it is rather difficult to define the position of Bulgarian semiotics therein, since it includes two internationally recognized structuralists - Kristeva and Todorov - but is nevertheless strongly influenced by Eco's writings. Every chapter is complemented with examples mostly from Bulgarian mass-media, explaining semiotic categories, ideas, concepts, areas of research and approaches. Bankov states that it was absolutely necessary for semiotics to be referred to as a science when it initially emerged decades ago, and nowadays semiotics still needs to be regarded/taught as a science 
for didactic reasons. However, as a philosopher, he suggests semiotics to be a "simple philosophy" for everyone. The second part of Semiotic Notebooks, published in 2004, is a philosophical essay on the problems of human identity, personal and collective memory, human self-identification. Here, Bankov applies semiotic analysis to describe the dynamics of identification processes in a Western-type society.

\section{- Ageev's Semiotics (2002)}

The book provides a brief introduction to the topic of semiotics. Although mentioning the work of Peirce, the author does not speak much about the history of the discipline. Insights into the notions of 'sign', 'sign systems' and a set of other essential categories are further complemented by chapters on computer semiotics and applied semiotics.

The author's own interest in the field of cybertechnologies is manifested through hinting at the scope of practical application of semiotics in the analysis of storing and retaining of information, creation of automatized systems for coding and decoding of information through discussing both natural as well as artificial languages. The author seeks to substantiate the use of semiotics and, more specifically, the structuralist approach, in the field of his own interest of cognitive computer graphics.

\section{- Gensini's Elementi di semiotica [Elements of semiotics] (2002)}

The small textbook by Stefano Gensini from the University of Rome is dealing mostly with semiotics of language and refers to many linguistic theories, also discussing the limits of semiotics and the relations to linguistics and semiotics. The book concentrates on the natural basis of semiosis and studies the modes of communication of human beings and other species, based on their different use of codes. Among the important authors of linguistics and semiotics discussed are Chomsky, Hjelmslev, Barthes, Eco, Humboldt, Jakobson, Lakoff and Johnson, Morris, Saussure, Vygotsky. Also the works of Darwin and Deacon are used as the basis for studying the differences between species, and their evolution. Gensini describes the origins of language and the development of the brain of different species ("language centre"). In terms of differences in sign use, the book gives examples of iconicity, arbitrarity, and conventionality. Describing the influence of creativity on the use of codes, Gensini differentiates between "regular", "non-regular", and "rule-based" creativity on the basis of the writings of Chomsky and Wittgenstein. Besides the development of language skills and the organs related to verbal communication, reference is also made to non-verbal communication and the study of gestures. Gensini describes the development of written language from the Egyptian ideograms to the contemporary versions of text and hypertext ("open text") and studies the limits of the term 'text'. The book is more an introduction to the studies of communication and language use, and less to semiotics in general. 
- Kjørup's Semiotik [Semiotics] (2002, 2nd ed. 2006, 2009 - trans. into German 2009) A good Danish introduction to semiotics that provides a brief account of "profiling" semiotic studies as a scientific discipline. It covers major semiotic topics in semiotics (sign, language, speech act, discourse, sign system, denotation/connotation, etc.). In the first part of textbook ("Why semiotics?") he has set the aim to explain the real value and importance of semiotic inquiry into the field of scientific activity. In the second part, Kjørup gives a short overview of both Peircean and Saussurean semiotics. In the final chapter the author proceeds with a glossary of semiotics which includes the key notions and concepts. Both Saussurean and Peircean semiotics are described.

- Pocheptsov's Semiotics (2002, 2nd ed. 2009)

The first half of the book by Pocheptsov, an expert in informational politics, communication and public relations, entitled "Basics of semiotics" provides an introduction to semiotics in which the author touches upon various aspects of basics and theory of semiotics, e.g. the question whether semiotics is a science or a methodology, relations between sign and symbol, language and communication, etc., supporting it with comprehensive references to major theorists of semiotics (Lotman, Eco, Barthes). Following Eco, Pocheptsov interprets semiotics as a type of universal analysis which is applicable within two already existing theories - theory of communication and theory of signification, although he limits its importance and does not go beyond the social aspects of semiotics. The author also refers to such semiotic universals as Peirce's trichotomy, Jakobson's model of communication, Lotman's binary oppositions, etc., although he observes them from the point of view of sociology and imagology. The examples focus on semiotics as a methodological attitude towards the social phenomena of campaigning, image making, and public relations.

The second half of the book entitled "Semiotics of Soviet civilization" can be seen as a case study, an example of semiotic analysis of a particular culture and society. As the author says, semiotic analysis results in a comprehensive view of the objects acknowledged by humans where the particular attention is given to the objects created by humans themselves.

\section{- Crow's Visible Signs: An Introduction to Semiotics (2003)}

With his book, David Crow has set an aim "to explore the mechanics of visual language in an attempt to help you understand how visual communication works" (Crow 2003: 8). The book is fairly relevant in this respect: the visual part of the book does not serve just as an object of analysis, but is used also as part of the language in which the author is delivering the message. The design, the layout and the illustrations are thus just as substantial a part of the book as the verbal message accompanying them. 
The book starts with the introduction of Peirce's and Saussure's concepts of sign, followed by the introduction of some basic concepts of semiotic theory such as semiosis, value, code, etc. Crow's book further contains chapters concentrating on the relation between the text and an image, the formation of official and unofficial language, and symbolic creativity. The author has stepped aside from the traditional step-by-step logics of textbooks in their introduction of concepts, theories or history. Topics like the theory of trash and rubbish and the use of rubbish in arts do not necessarily bear a direct link to what was written before, yet provide necessary hints to the undercurrents of semiotics, to the not-so-widely-discussed topics that would deserve more attention from the community of semioticians. The chief value of the book lies in its ability to reach the addressed audience by bordering its semiotic field with the topics most relevant for people working with visual media and has thereby really used the medium as the message.

\section{- Maglis Semiotica: Teoria, metodo, analisi [Semiotics: Theory, Method, Analysis] (2004, 2nd ed. 2005, 3rd ed. 2008)}

Patrizia Magli's book does not cover the whole field of semiotics, but deliberately concentrates on a single section of it - the analysis of (artistic) texts. More precisely, it focuses on the theoretical thought of Propp, Hjelmslev, and Greimas (while several great names of semiotics, most notably Peirce, are made no mention of). The aim of the book is to give a simple, but not simplified overview of the analytical tools for "exploring the mechanisms by which texts function" (Magli 2004: 46). In other words, the work attempts to provide the reader with a clear framework for the empirical study of texts. The basis is built on the Saussurean notion of sign and on the relation between the content form and expression form. Step by step, the work gives an overview of the more complex levels of the structural organisation of texts.

The book is well structured and thus constitutes a quite clear introductory reading for students with at least some university-level academic background. The "textbookish" features include test questions and exercises after each chapter, and two exemplary analyses as an appendix.

- Mechkovskaya’s Семиотика: Языю. Природа. Культура [Semiotics: Language, Nature, Culture] (2004, 3rd ed. 2008)

The author, a linguist from the Belarusian State University, provides a systematic course of semiotics in 20 lectures. The course begins with the basic notions of semiotics and the description of the place of semiotics in humanities and sciences followed by a review of the history of semiotics. Taxonomy of the classes of signs and sign systems is based on their ontogeny. Elementary signs (icon, index, symbol) are divided according to the modality, types of motivatedness and the level of conventionality. Several lectures 
are devoted to a detailed analysis of structure and functions of particular sign systems (ritual, dance, music, literature, artificial languages, etc.). On the plane of content, the author distinguishes four aspects - denotatics, semantics, syntactics, and pragmatics (Mechkovskaya 2008: 218) with reference to G. Klaus and A. Suprun. In describing the sign systems of culture, she focuses on semiotic practices. The last lecture formulates some rules of development of sign systems, and speculates about the further role of semiotics as a methodology for the humanities.

- Solomonik's Позитивная семиотика [Positive Semiotics] (2004)

Solomonik's monograph focuses on the semiotic concepts that the author considers to be most important, such as sign, sign system and sign (semiotic) activities. His intention is to employ "the deepest layers of semiotic analysis" (Solomonik 2004: 3). As he notes, "in contemproray semiotics there are no single, or at least more or less coherent, views on the most important of its components, neither is there any agreement on what exactly constitutes semiotics as a science, what is semiotics' object of inquiry/purpose and what semiotic methods of analysis actually are" (Solomonik 2004: 3). The uniqueness of Solomonik's approach consists in his radical denial of already established paradigms of semiotic inquiry (for instance, he harshly criticizes Peirce's "divisions of signs"). However, as he is aiming at the construction of positively re-stated semiotic, his ambitions go even further beyond a simple anathema to existing semiotic methods. He warns the reader, "I use only the most basic part of semiotic theory, revising it according to my own views [...]. In such a situation, there are many benefits that enable me to build, as it seems, something integral 'from scratch'. I would therefore like to warn the reader that most of the findings and conclusions, which he will find below are the fruits of my very own ideas and thoughts. I have no one to refer to" (Solomonik 2004: 4). However, while developing semiotic theory from an "integral" point of view, Solomonik is more concerned with ontological and epistemological groundings of "positive" semiotics than with "semiotics proper".

\section{- Proskurin's Essays on Current Semiotics (2007)}

This is a small, 75-page booklet, "conceived as an introduction to the field of today's semiotics" (Proskurin 2007: 4), and, according to its subtitle, The Textbook to the Course of "Semiotics". The book consists of two parts. The first part, "Semiotic retrospective", gives a brief many-sided overview of the central concepts in semiotics, relaying on Peirce, Saussure, Uexküll, Sebeok, and others. The second part, "Semiotic perspective", describes Proskurov's main reasearch area - Indo-European ethnosemiotics.

\section{- Danesi's The Quest for Meaning: A Guide to Semiotic Theory and Practice (2007)}

Danesi is the author of several introductions to semiotics. This one, a newly written version of the Messages and Meanings (1994, 1998, 2004), is quite human- and 
language-centred. Its scope becomes clear already from the book's introduction, where Danesi repeatedly stresses the nature of semiotics as a discipline mainly focused on understanding human species and its sign processes.

Chapter 1 introduces the main trends, ideas and people in semiotics, ending with the Saussure-Peirce duo. Chapters 2-6 deal with the theoretical and methodological apparatus, outlining the essential concepts: sign, structure, code, text and representation. Chapter 7 is dedicated to applied semiotics and attempts to implement semiotic theory in order to improve understanding of the aspects of everyday life (food, clothing).

Each chapter ends with a list of topical books and, separately, web resources. The book concludes with a laconic glossary.

\section{- Hall's This Means This, This Means That: A User's Guide to Semiotics (2007)}

Divided into 75 key concepts discussed through examples, Sean Hall's 'user's guide' is an attractive introduction to semiotics that is targeted at the most general audience. On the one hand, the use of visual examples, explanatory texts on various levels and the careful structuring of the material enables the book to serve as a useful tool for talking about semiotics even to children. On the other hand, the several levels of explanations go considerably deeper into the concepts, while avoiding details and contradictory definitions unnecessary for non-academic user. Inside the general field of semiotics, the general stance of the book is close to communication studies and discourse analysis.

\section{- Voig's Bevezetés a szemiotikába [Introduction to Semiotics] (2008)}

Voigt provides the reader with an original Hungarian-language treatise on the development of semiotics as a discipline within Western thought. The contribution of Peirce and modern logic to semiotics has merited a whole chapter, yet the treatment of structural linguistics as a component of semiotics through various European schools is remarkably more thorough. The author has devoted several chapters to Hungarian semiotics and long passages to developments within the Hungarian culture. Voigt's work, richly illustrated with diagrams and schemata (e.g, a table on developments in Western thought noteworthy for semioticians), includes a thorough bibliography and an overview of the state of the art in semiotics - schools, journals, universities and national traditions. On the whole, it is useful as a handbook on the theoretical and institutional development of semiotics for the novice, which does not rule out its use as a university coursebook. 
Kalevi Kull et al.

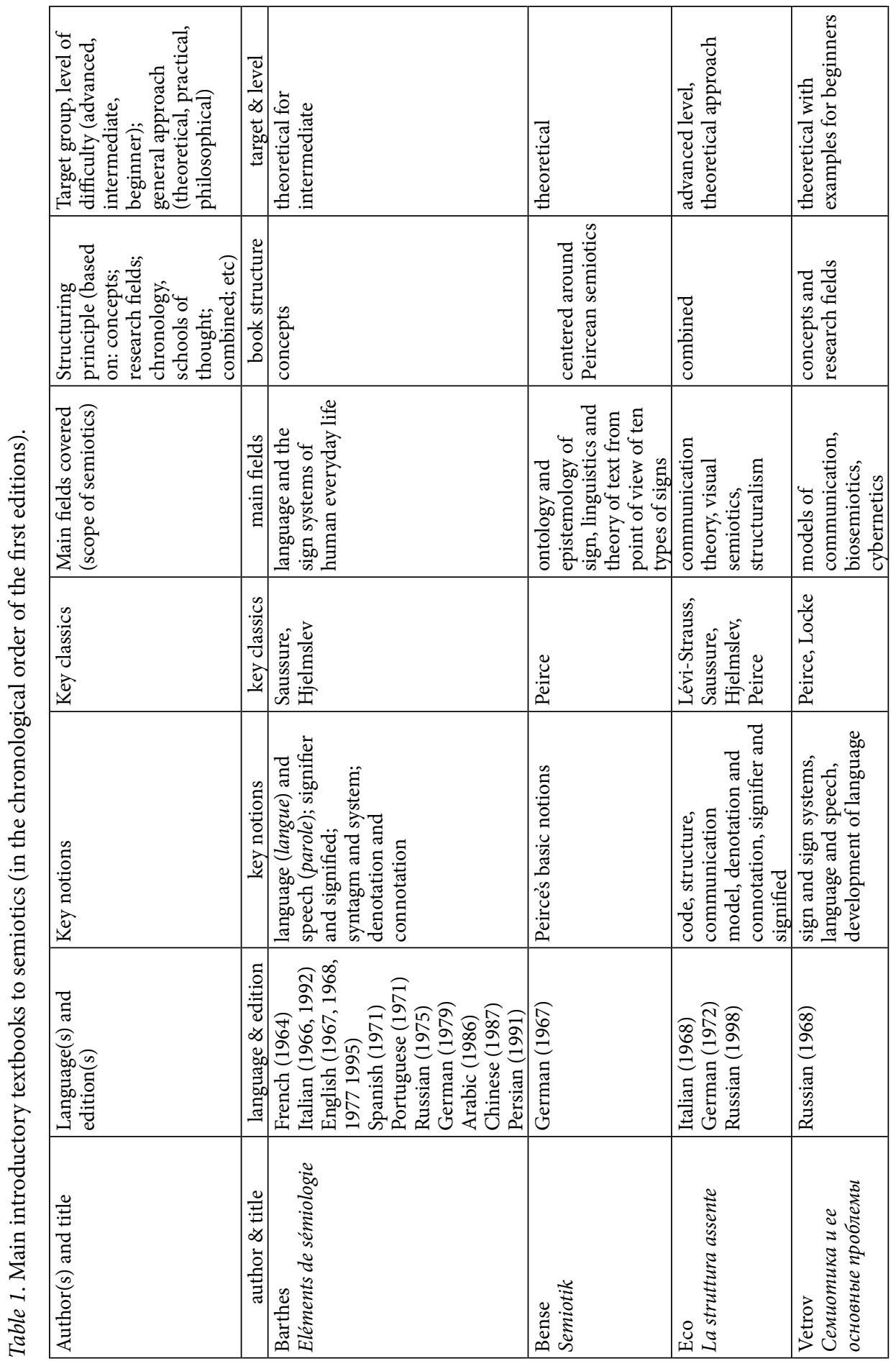




\begin{tabular}{|c|c|c|c|c|c|}
\hline 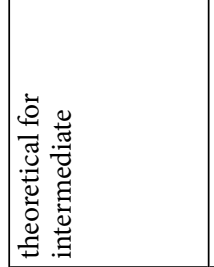 & 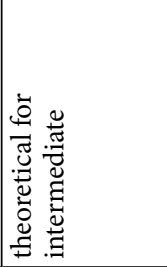 & 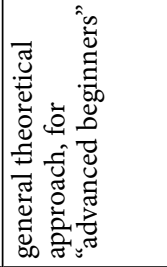 & 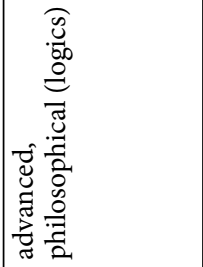 & 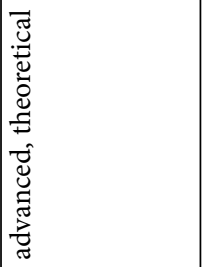 & 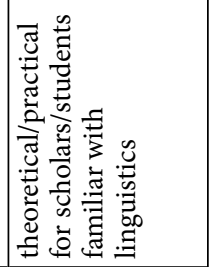 \\
\hline 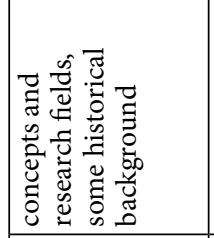 & 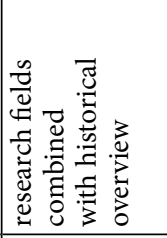 & 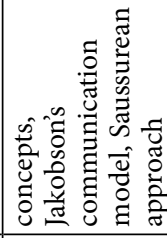 & 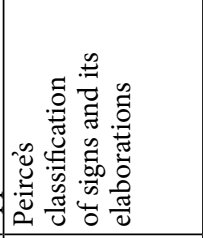 & 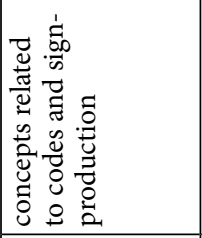 & 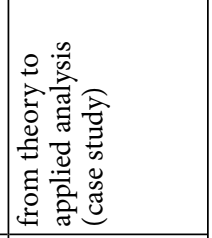 \\
\hline 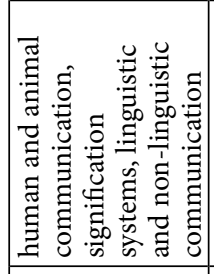 & 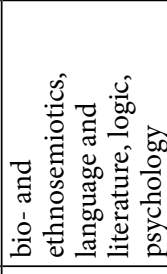 & 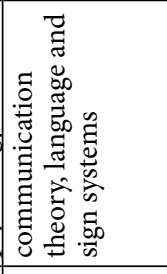 & 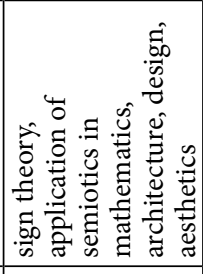 & 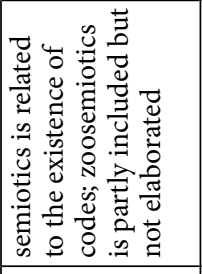 & 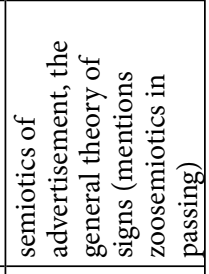 \\
\hline 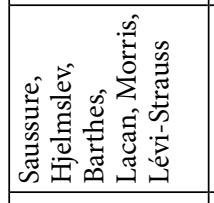 & 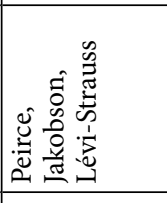 & 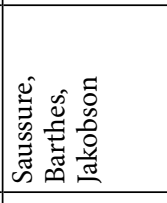 & 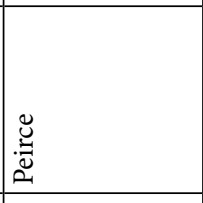 & 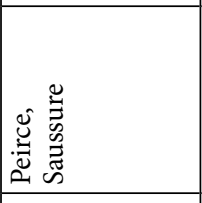 & 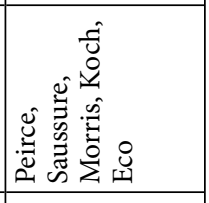 \\
\hline 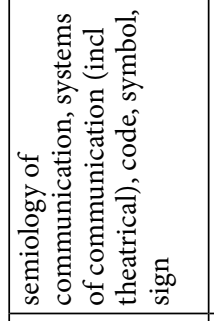 & 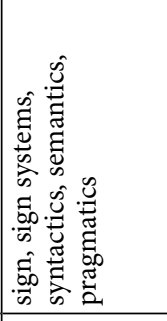 & 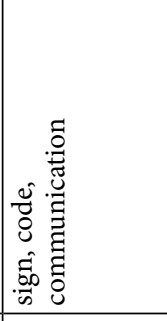 & 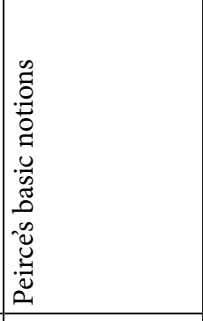 & 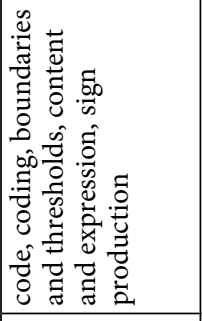 & 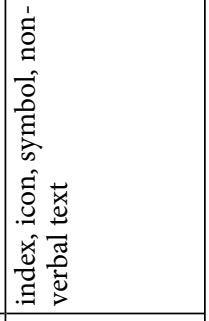 \\
\hline 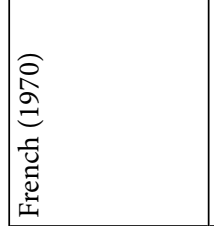 & 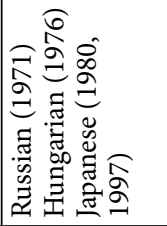 & 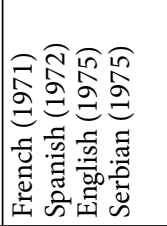 & 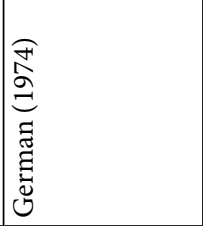 & 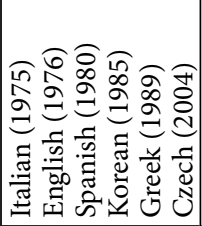 & 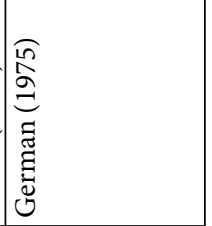 \\
\hline 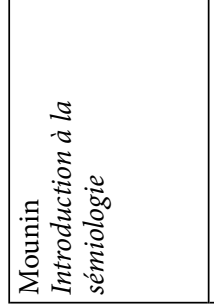 & 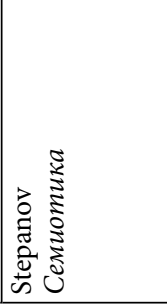 & 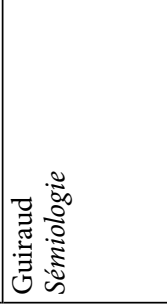 & 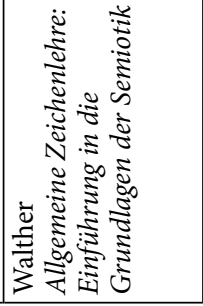 & 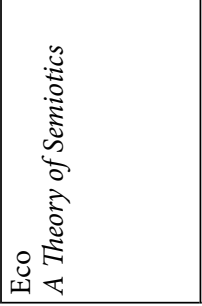 & 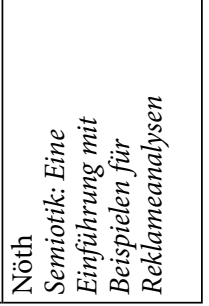 \\
\hline
\end{tabular}


314 Kalevi Kull et al.

\begin{tabular}{|c|c|c|c|c|c|}
\hline 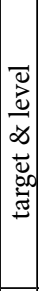 & 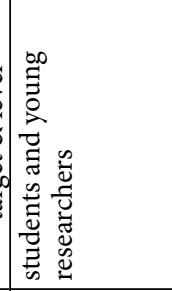 & 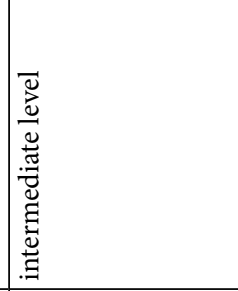 & 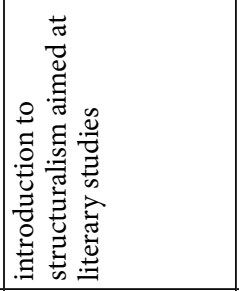 & 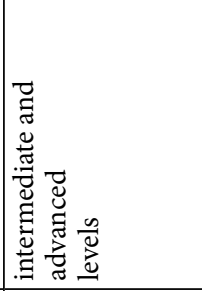 & 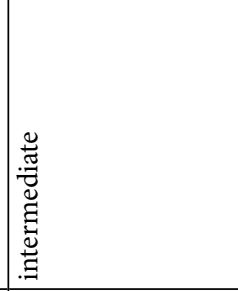 \\
\hline 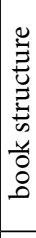 & 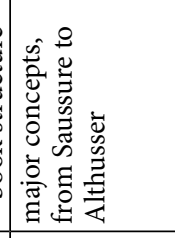 & 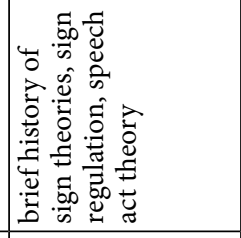 & 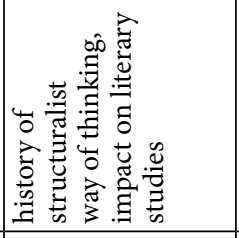 & 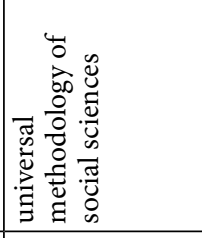 & 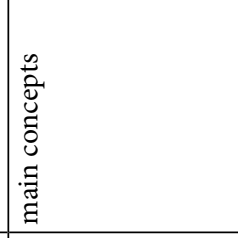 \\
\hline 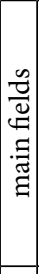 & 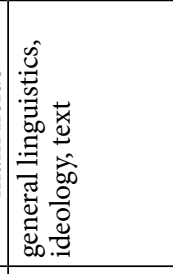 & 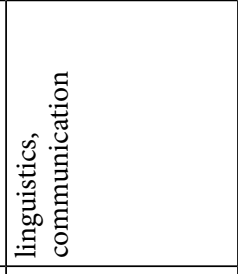 & 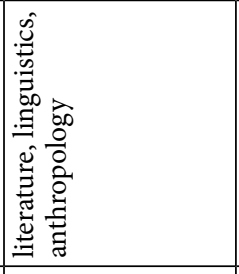 & 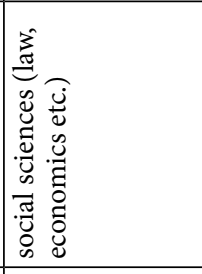 & 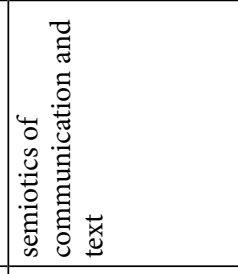 \\
\hline 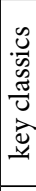 & 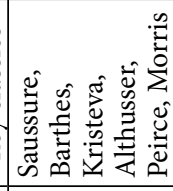 & 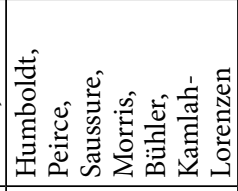 & 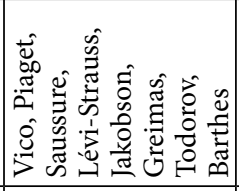 & 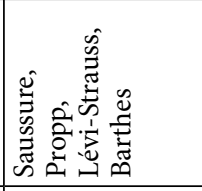 & 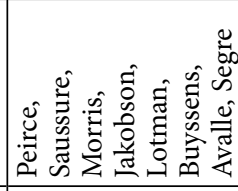 \\
\hline 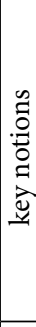 & 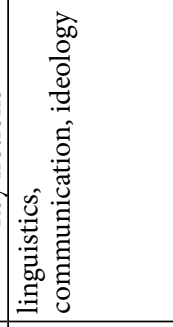 & 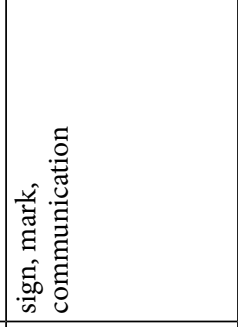 & 号 & 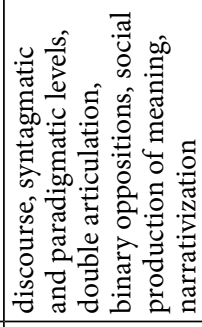 & 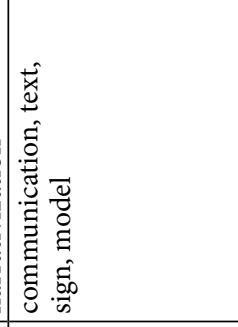 \\
\hline 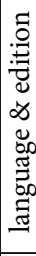 & 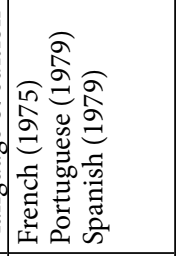 & 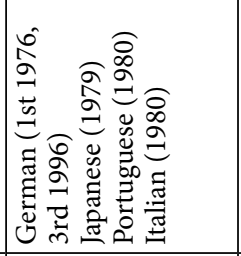 & 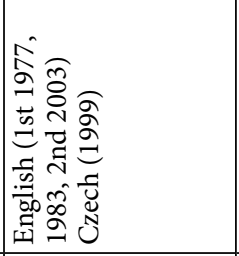 & 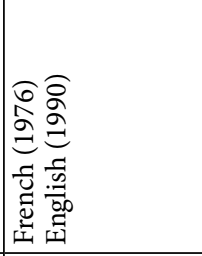 & 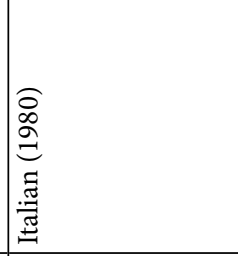 \\
\hline 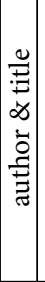 & 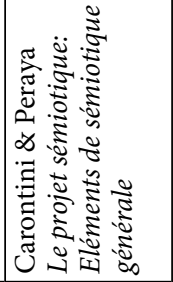 & 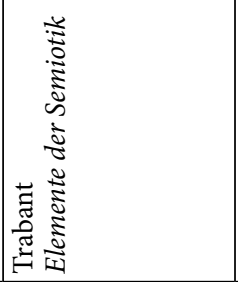 & 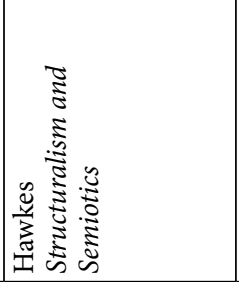 & 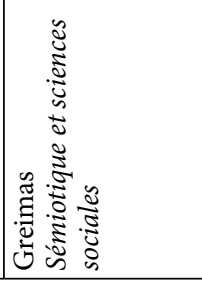 & 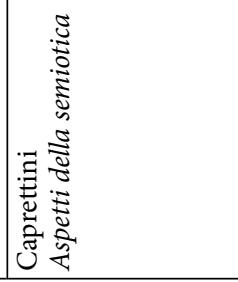 \\
\hline
\end{tabular}




\begin{tabular}{|c|c|c|c|c|c|c|c|}
\hline 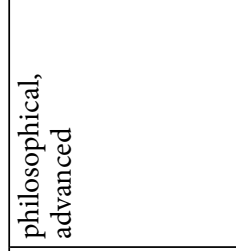 & 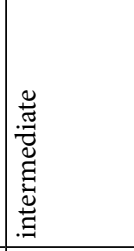 & 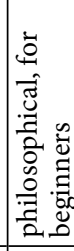 & 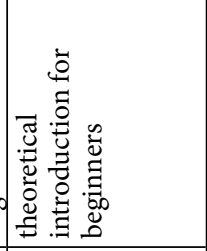 & 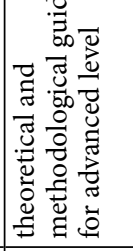 & 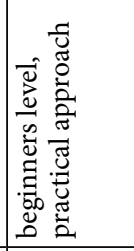 & 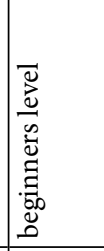 & 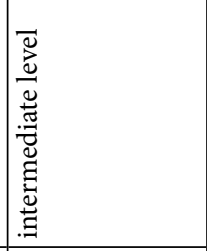 \\
\hline 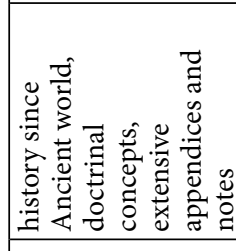 & 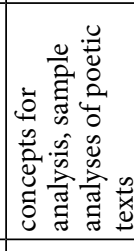 & 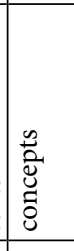 & 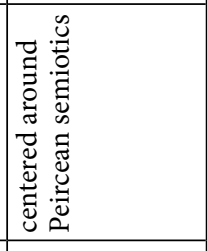 & 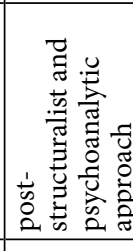 & 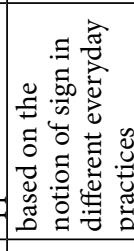 & 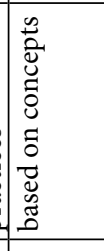 & 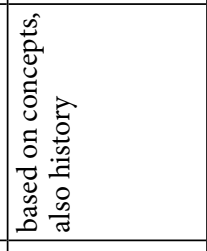 \\
\hline 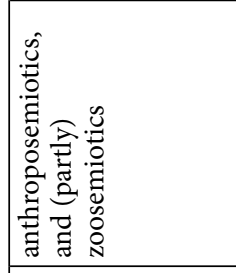 & 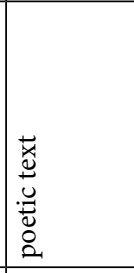 & 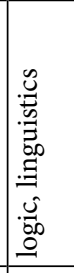 & 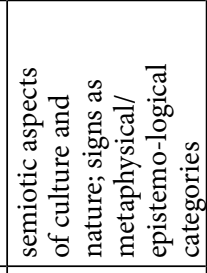 & 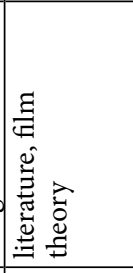 & 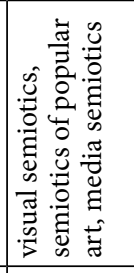 & 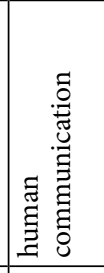 & 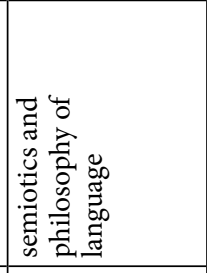 \\
\hline 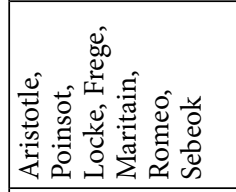 & 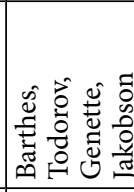 & 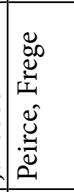 & 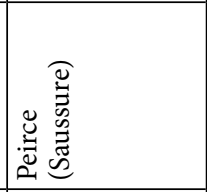 & 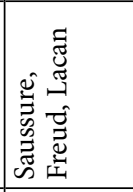 & 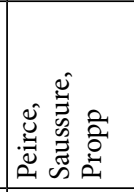 & 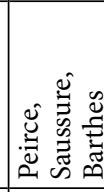 & 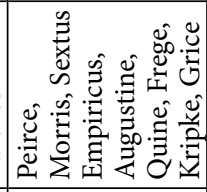 \\
\hline 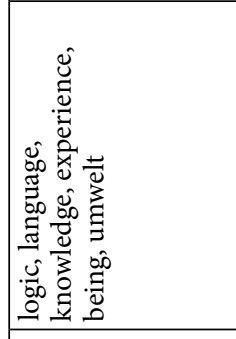 & 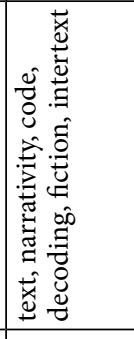 & 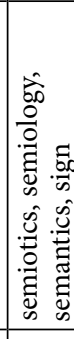 & 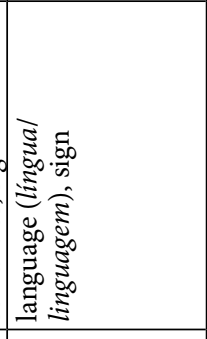 & 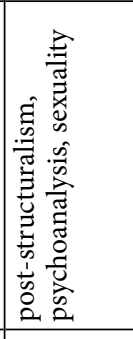 & 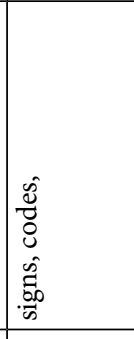 & 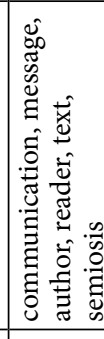 & 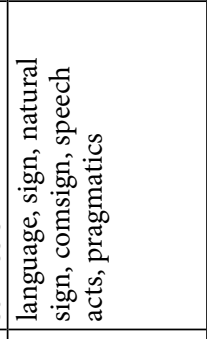 \\
\hline 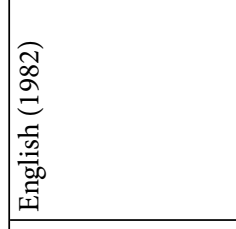 & 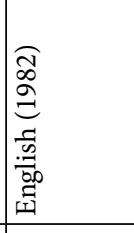 & 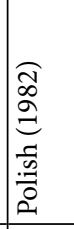 & 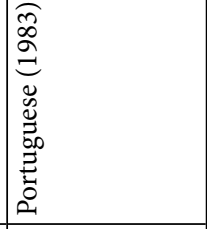 & 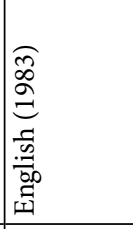 & 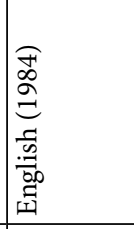 & 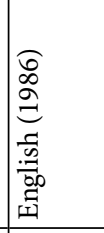 & 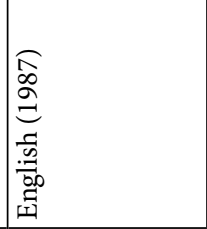 \\
\hline 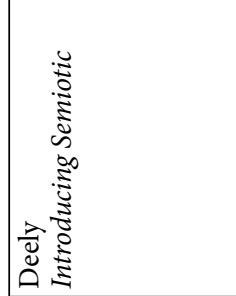 & 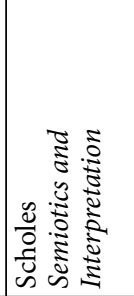 & 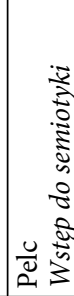 & 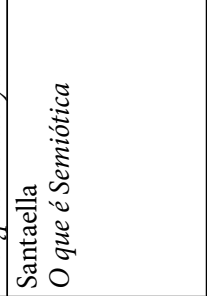 & 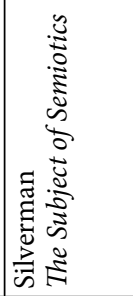 & 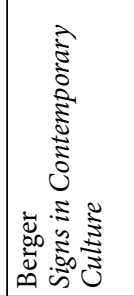 & 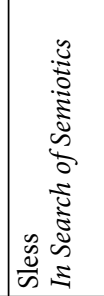 & 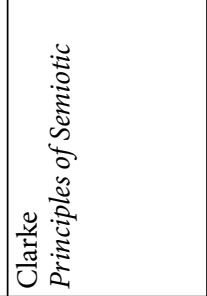 \\
\hline
\end{tabular}


316 Kalevi Kull et al.

\begin{tabular}{|c|c|c|c|c|}
\hline 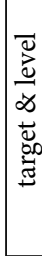 & 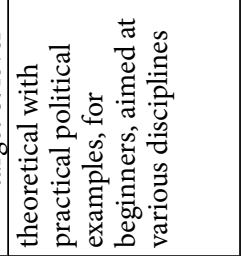 & 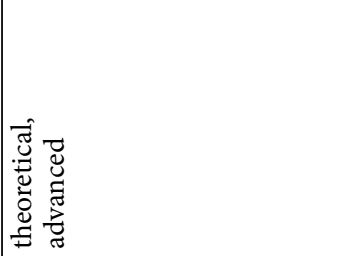 & 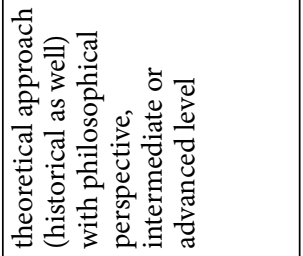 & 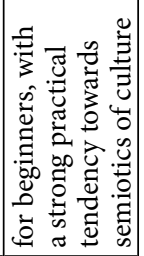 \\
\hline 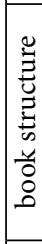 & 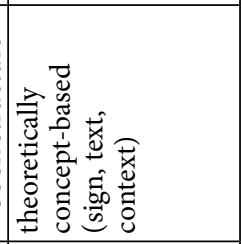 & 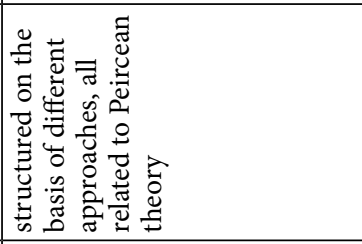 & 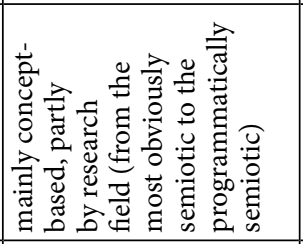 & 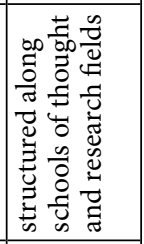 \\
\hline 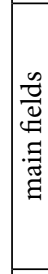 & 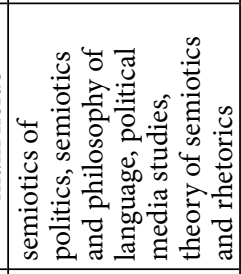 & 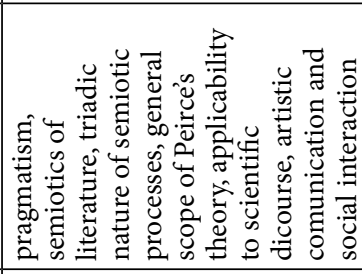 & 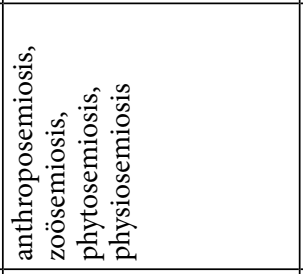 & 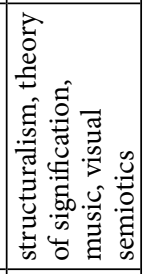 \\
\hline 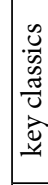 & 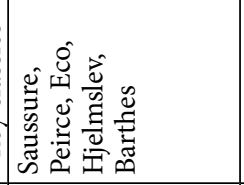 & 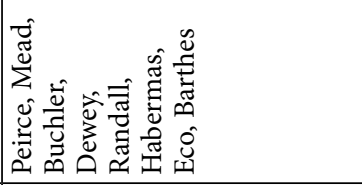 & 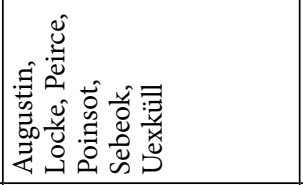 & 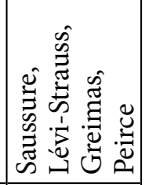 \\
\hline 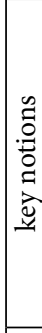 & 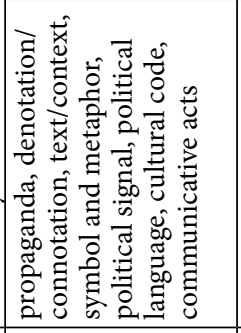 & 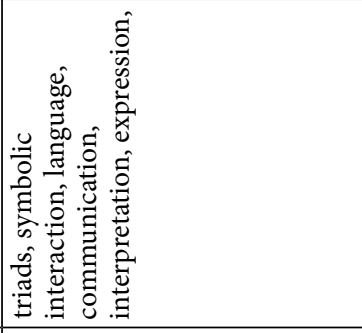 & 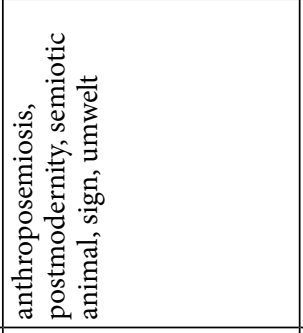 & 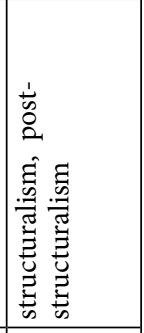 \\
\hline 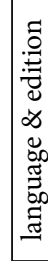 & 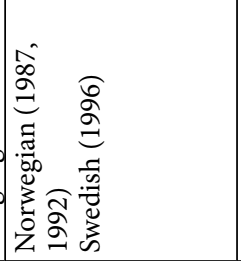 & 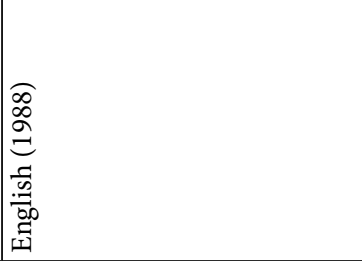 & 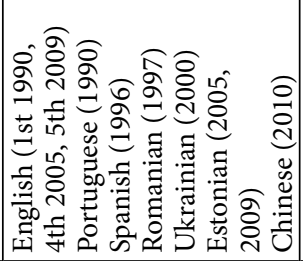 & 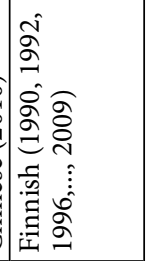 \\
\hline 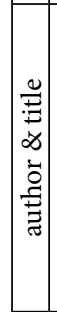 & 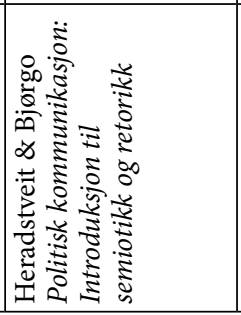 & 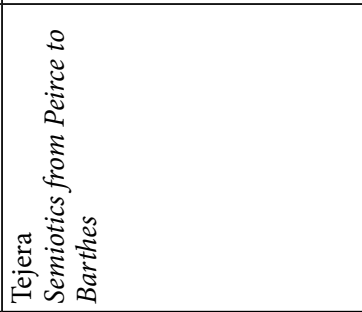 & 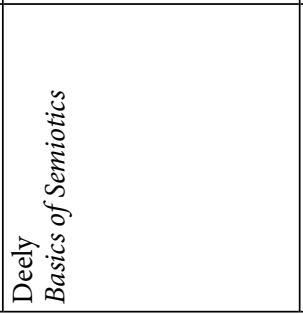 & 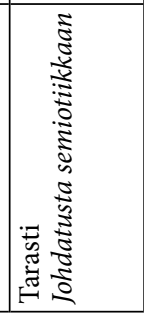 \\
\hline
\end{tabular}




\begin{tabular}{|c|c|c|c|c|c|c|}
\hline 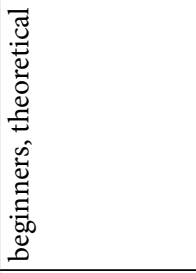 & 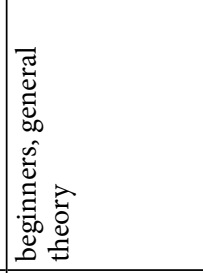 & 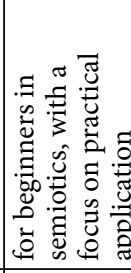 & 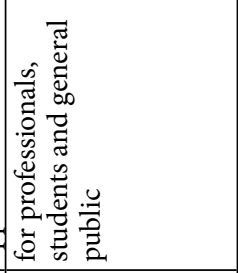 & 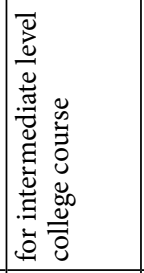 & 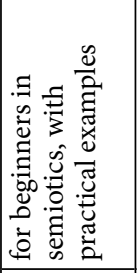 & 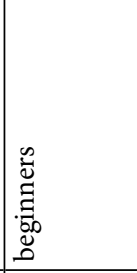 \\
\hline 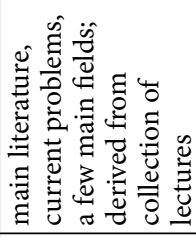 & 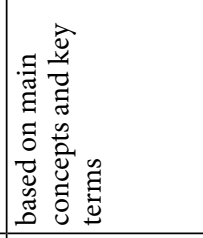 & 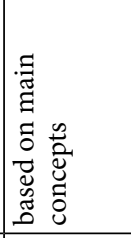 & 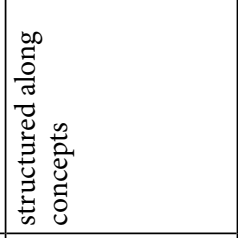 & 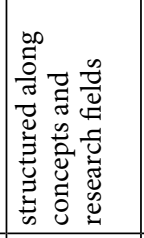 & 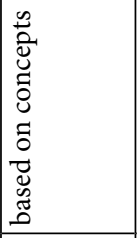 & 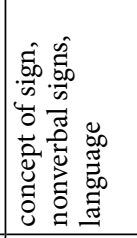 \\
\hline \multirow[t]{2}{*}{ 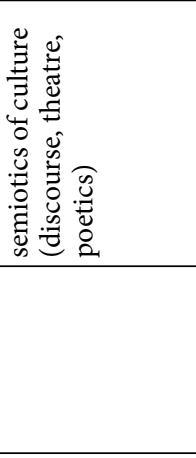 } & 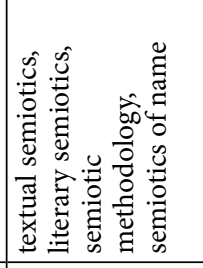 & 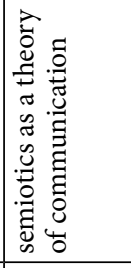 & 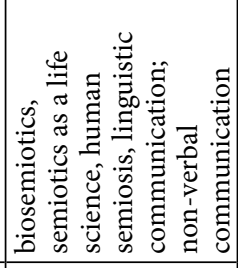 & 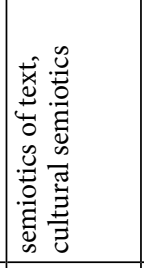 & 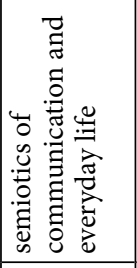 & 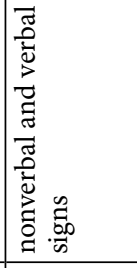 \\
\hline & 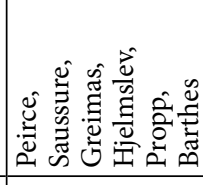 & 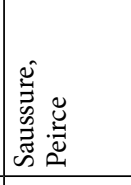 & 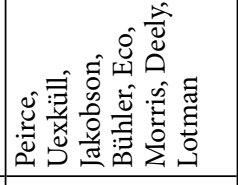 & : & 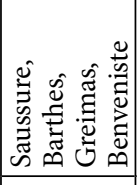 & 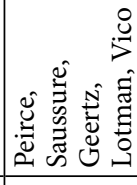 \\
\hline 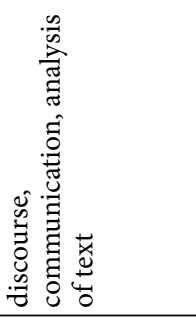 & 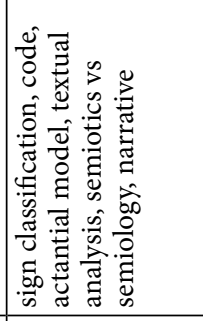 & 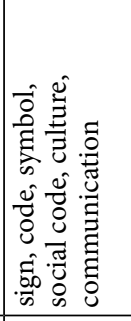 & 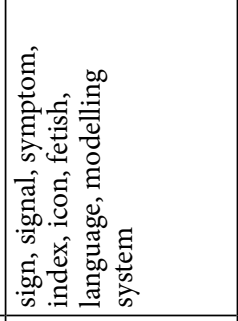 & 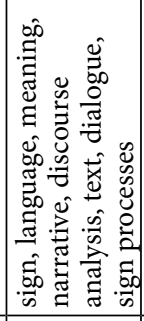 & 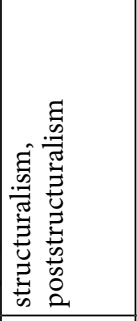 & 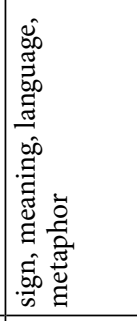 \\
\hline 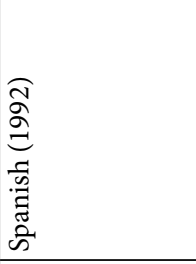 & 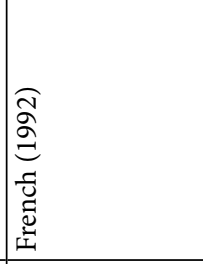 & 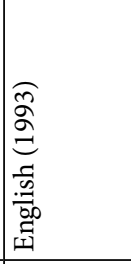 & 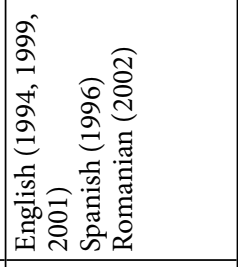 & 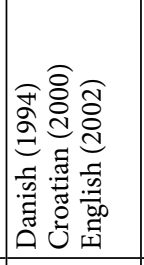 & 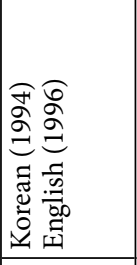 & 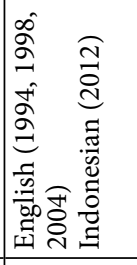 \\
\hline 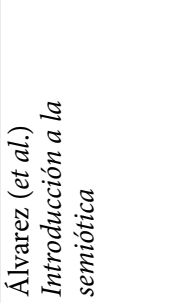 & 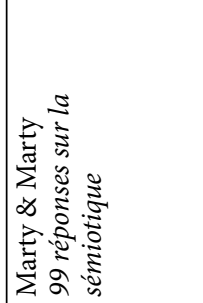 & 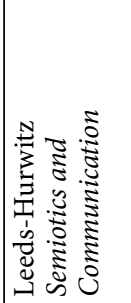 & 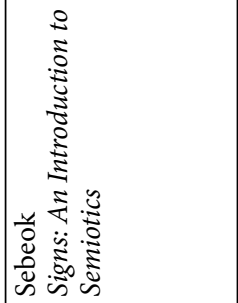 & 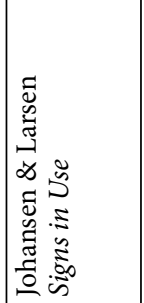 & 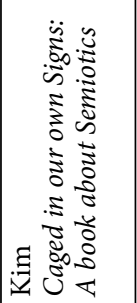 & 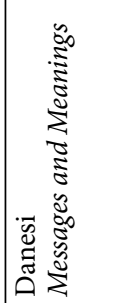 \\
\hline
\end{tabular}


318 Kalevi Kull et al.

\begin{tabular}{|c|c|c|c|c|}
\hline 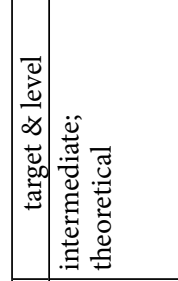 & 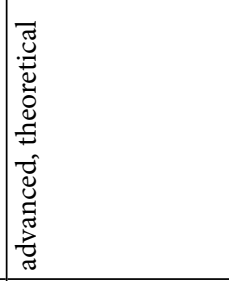 & 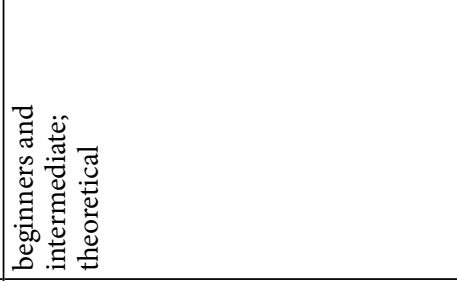 & 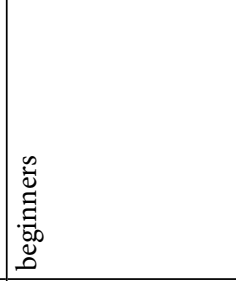 & 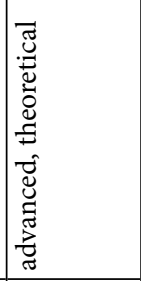 \\
\hline 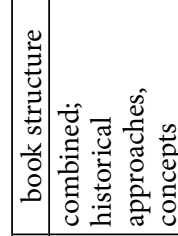 & 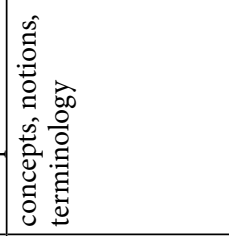 & 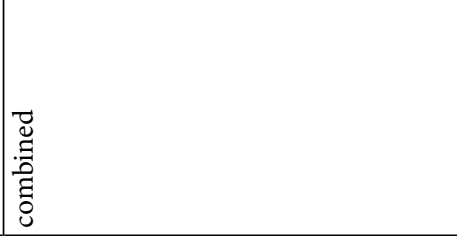 & 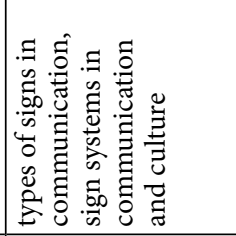 & 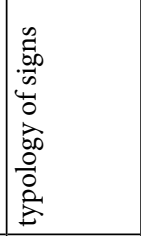 \\
\hline 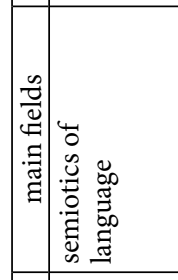 & 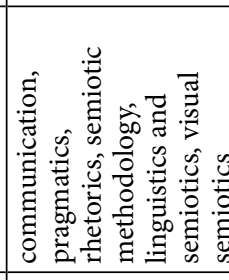 & 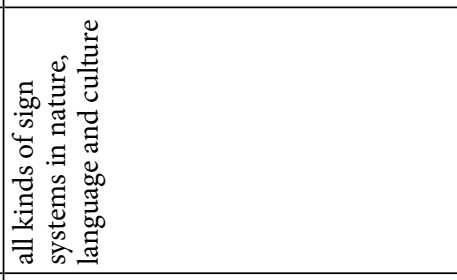 & 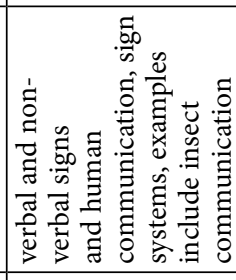 & 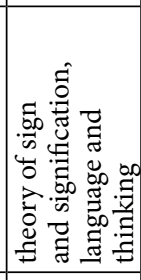 \\
\hline 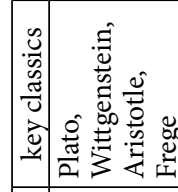 & 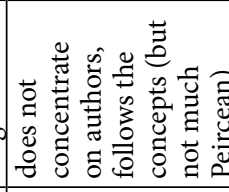 & 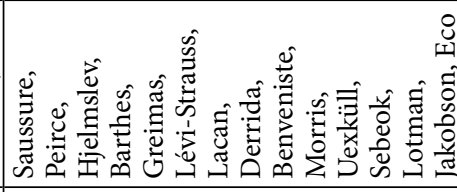 & : & 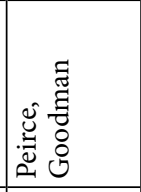 \\
\hline 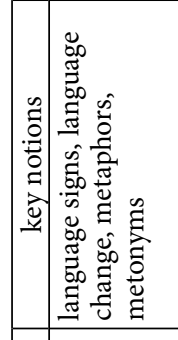 & 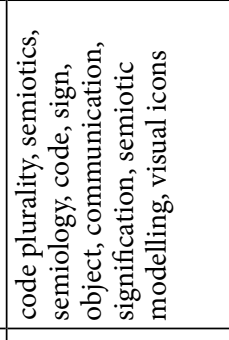 & 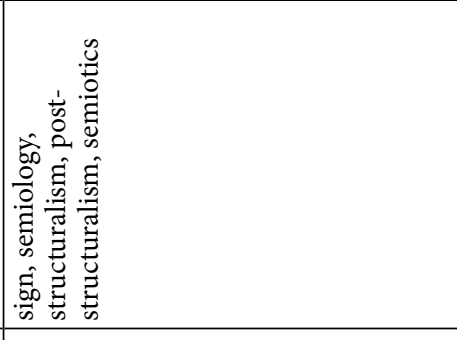 & 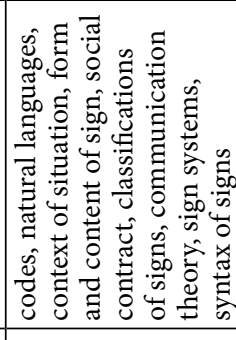 & 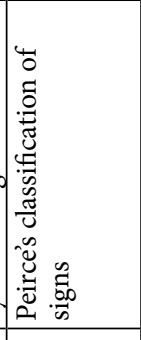 \\
\hline 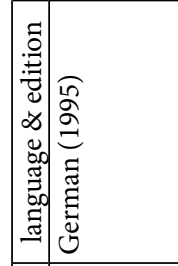 & 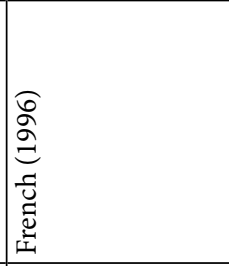 & 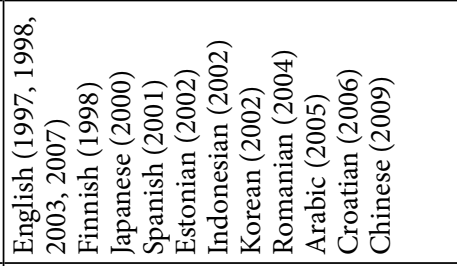 & 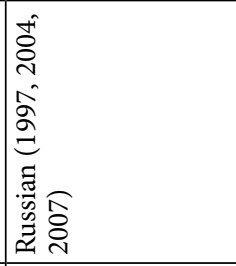 & 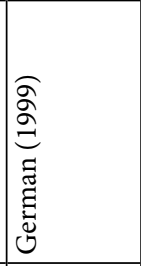 \\
\hline 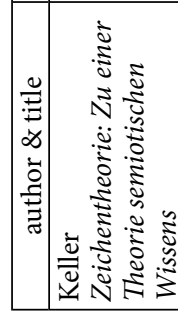 & 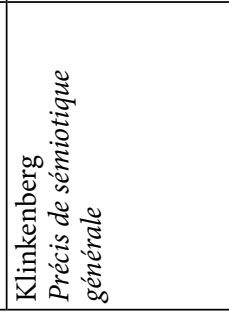 & 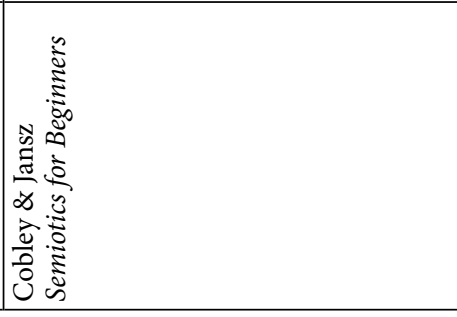 & 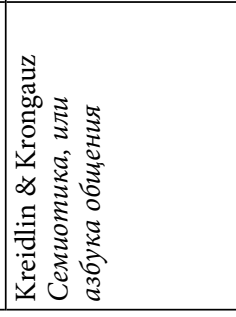 & 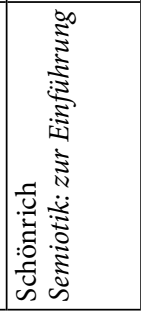 \\
\hline
\end{tabular}




\begin{tabular}{|c|c|c|c|c|c|}
\hline 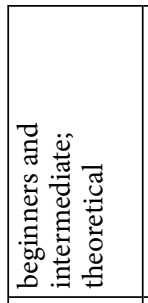 & 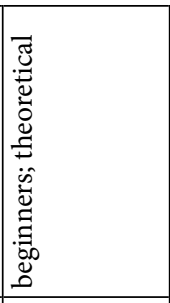 & 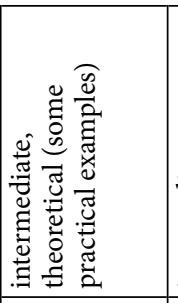 & 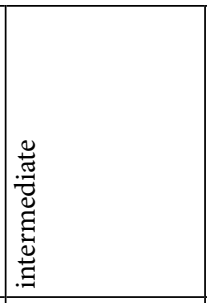 & 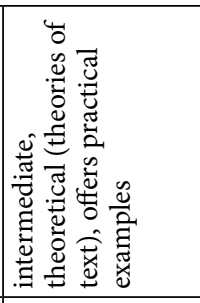 & 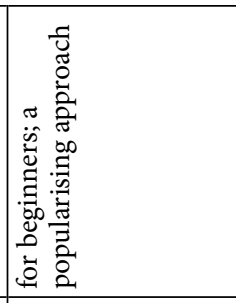 \\
\hline 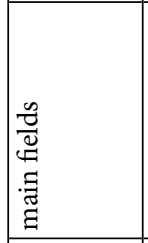 & 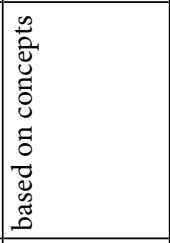 & 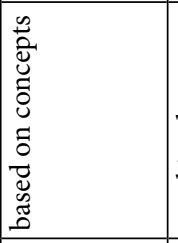 & 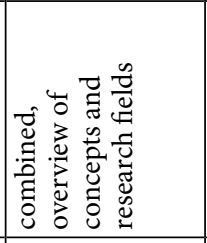 & 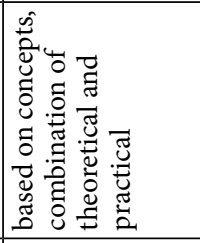 & 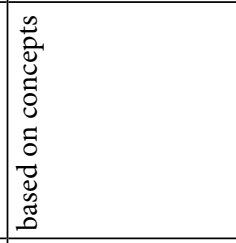 \\
\hline 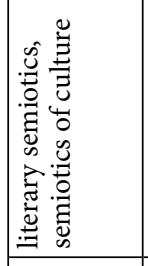 & 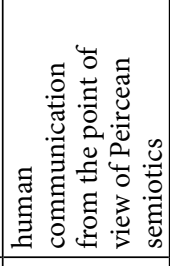 & 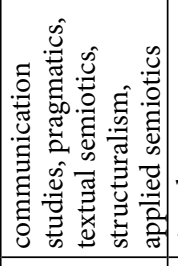 & 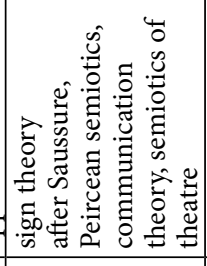 & 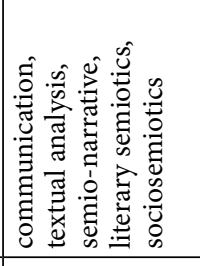 & 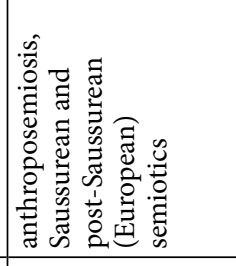 \\
\hline 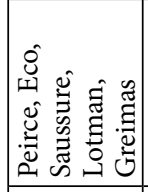 & 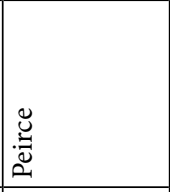 & 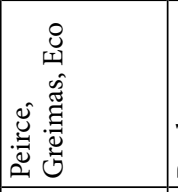 & 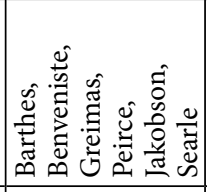 & 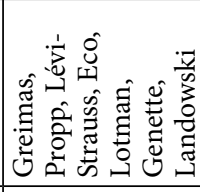 & 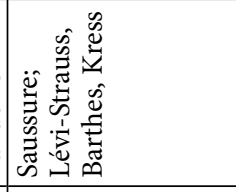 \\
\hline 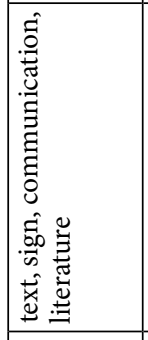 & 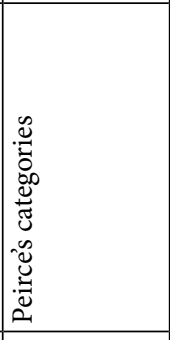 & 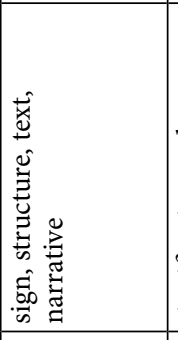 & 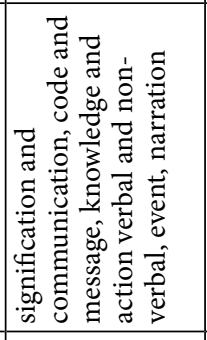 & 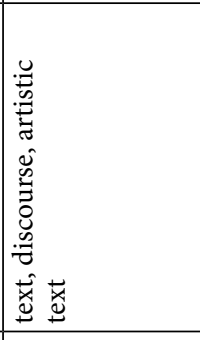 & 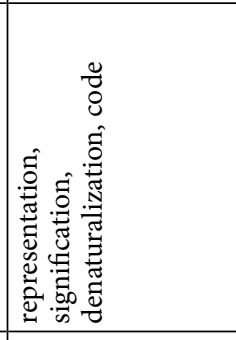 \\
\hline 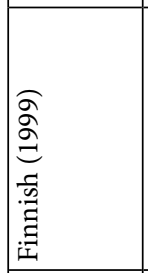 & 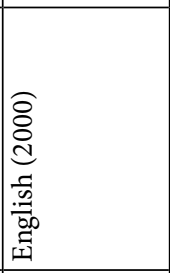 & 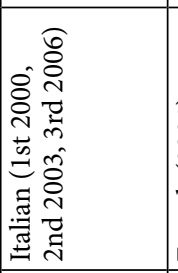 & 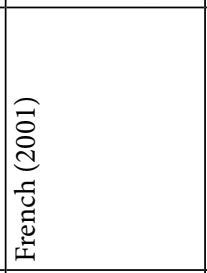 & 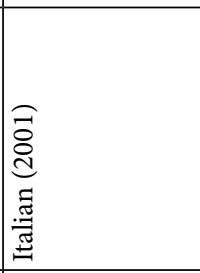 & 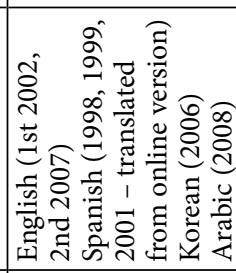 \\
\hline 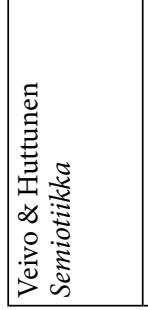 & 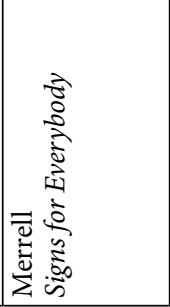 & 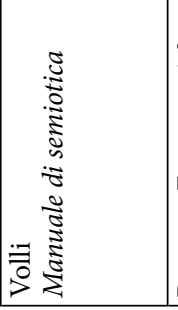 & 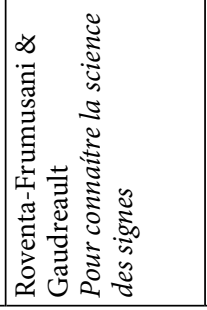 & 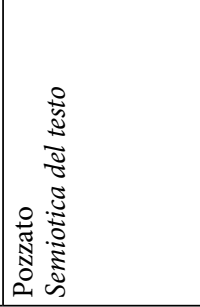 & 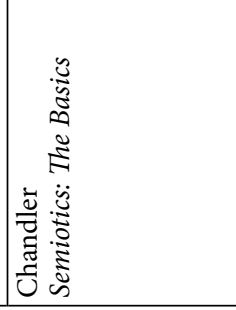 \\
\hline
\end{tabular}


320 Kalevi Kull et al.

\begin{tabular}{|c|c|c|c|c|c|c|c|}
\hline 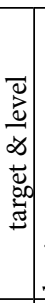 & 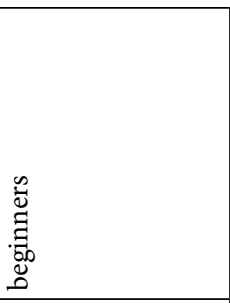 & 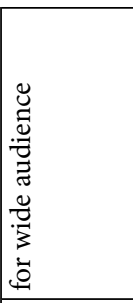 & 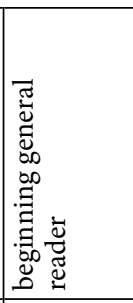 & 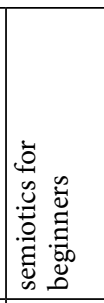 & 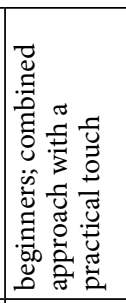 & 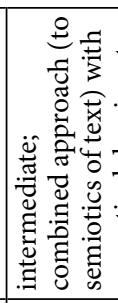 & 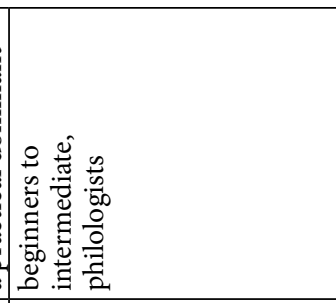 \\
\hline & 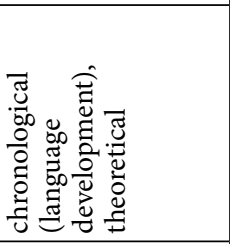 & 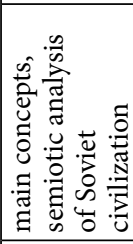 & 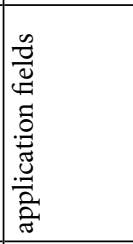 & 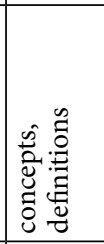 & 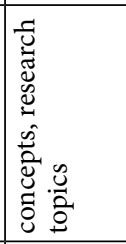 & 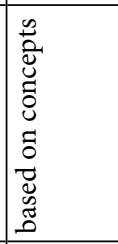 & 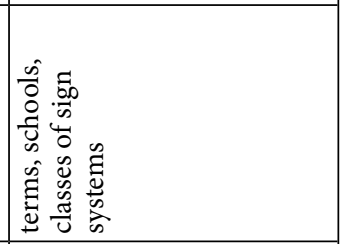 \\
\hline & 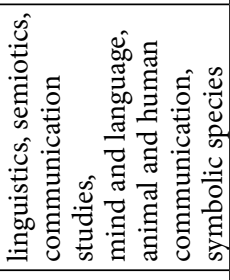 & 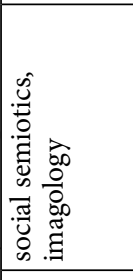 & 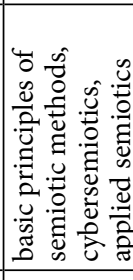 & 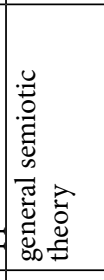 & 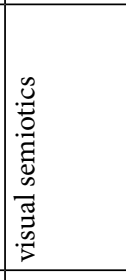 & 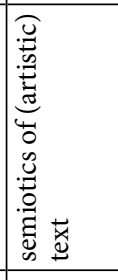 & 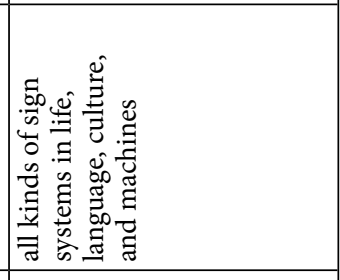 \\
\hline & 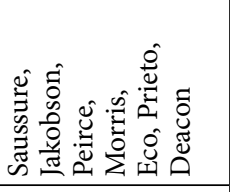 & 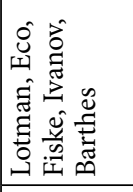 & 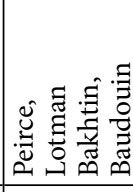 & 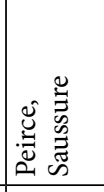 & 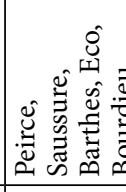 & 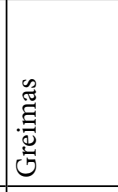 & 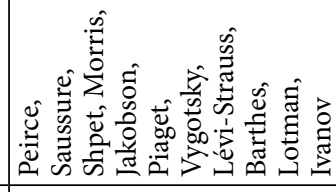 \\
\hline 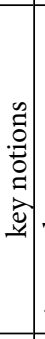 & 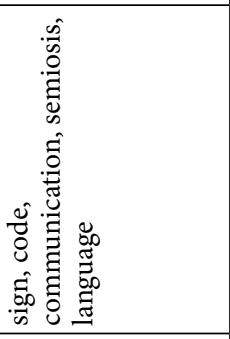 & 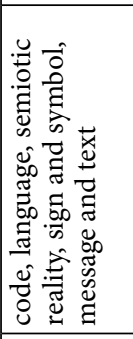 & 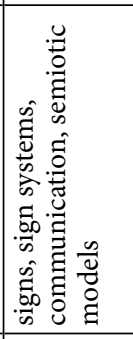 & 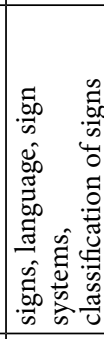 & 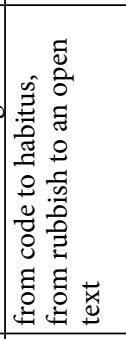 & 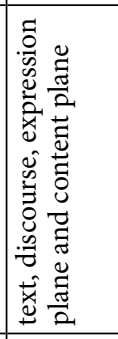 & 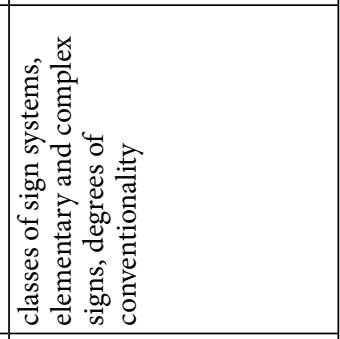 \\
\hline 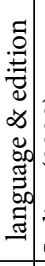 & & 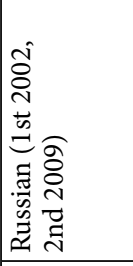 & 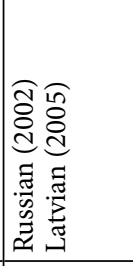 & 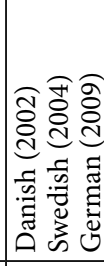 & 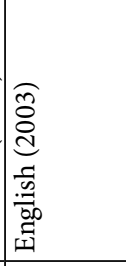 & 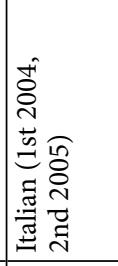 & 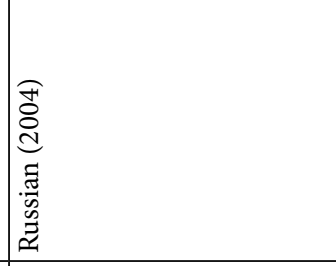 \\
\hline & 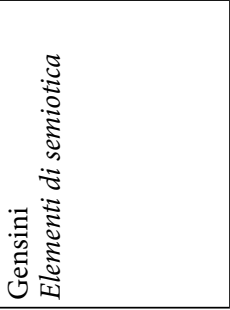 & 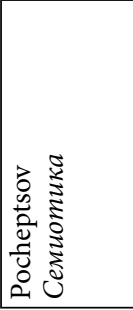 & 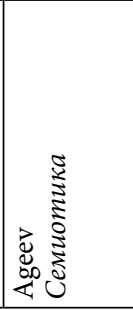 & 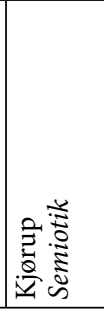 & 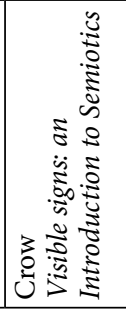 & 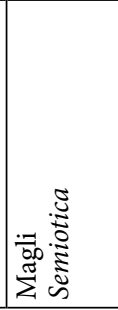 & 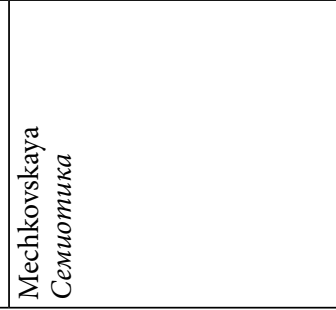 \\
\hline
\end{tabular}




\begin{tabular}{|c|c|c|c|c|}
\hline 莕 & 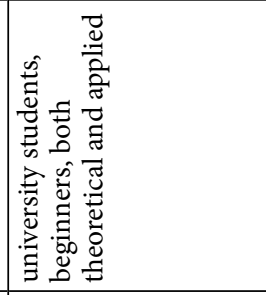 & 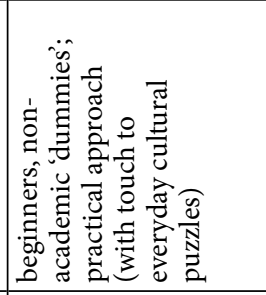 & 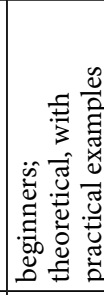 & 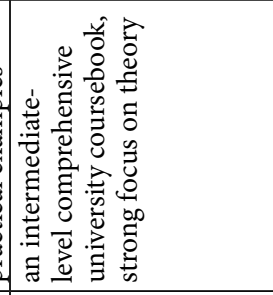 \\
\hline 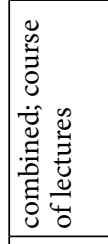 & 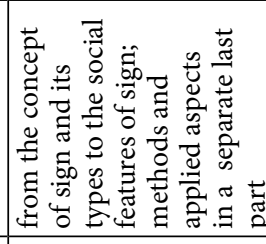 & 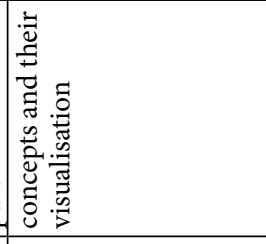 & 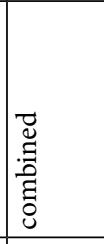 & 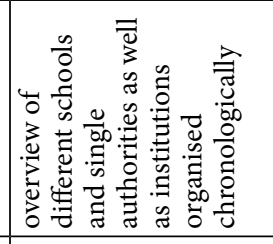 \\
\hline 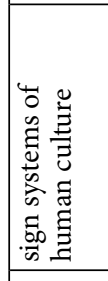 & 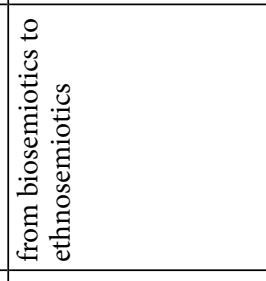 & 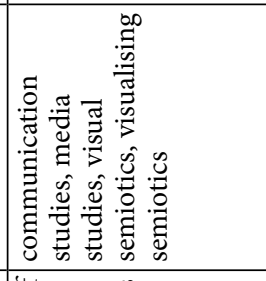 & 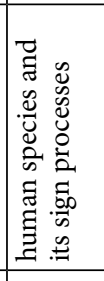 & 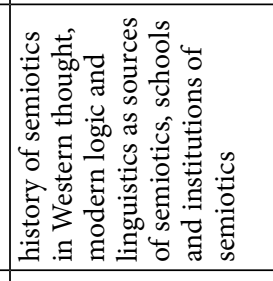 \\
\hline 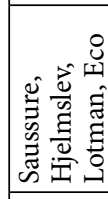 & 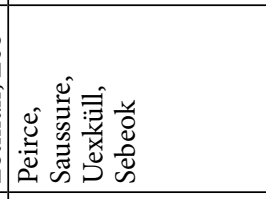 & 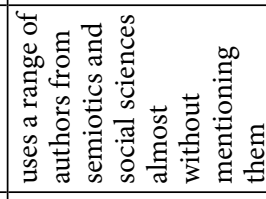 & 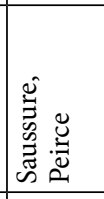 & 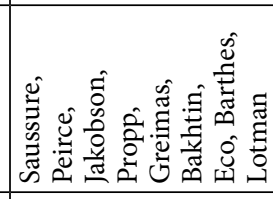 \\
\hline 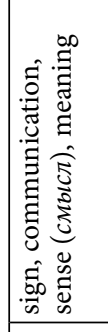 & 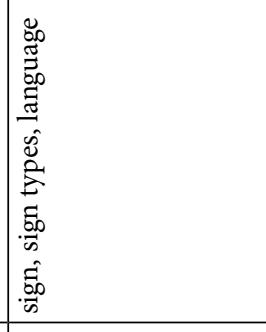 & 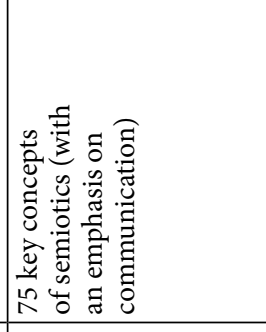 & 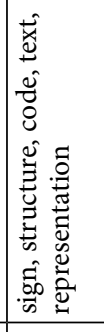 & 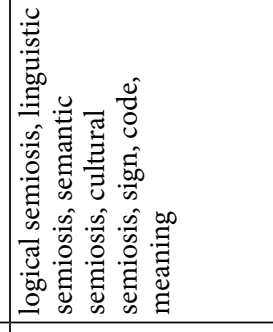 \\
\hline 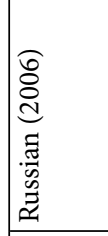 & 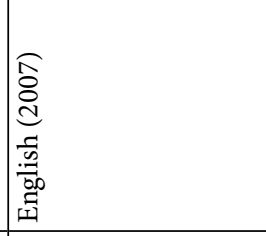 & 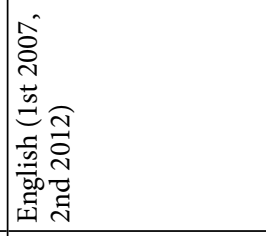 & 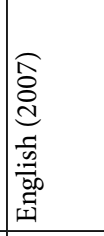 & 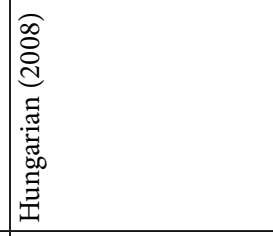 \\
\hline 竎 & 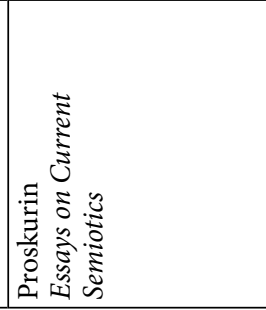 & 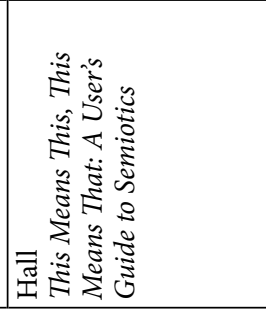 & 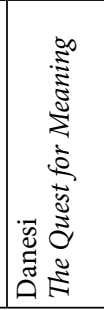 & 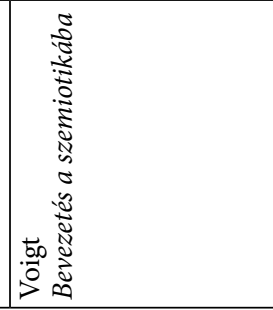 \\
\hline
\end{tabular}




\section{Observations and discussion}

The current review is limited only to the introductions and textbooks on general semiotics (205 titles, including translations), which means that we have not included books on specific branches of semiotics. Some of these textbooks we have described de visu and submitted to a more detailed analysis. Thus, above we gave brief reviews of 58 books: 12 published in the 1960s and early 1970s; 12 from the late 1970s and 1980s; 18 from the 1990s; and 16 from the 2000s). Table 1 provides a concise comparative account of 57 books.

\subsection{Main trends: some numbers}

Altogether we could find 132 original books from the period 1960-2009 that we identified as introductions to semiotics (plus 23 general dictionaries and encyclopedias in semiotics, and 16 readers and anthologies in general semiotics). From these, at least 20 titles have also appeared in translation, some have been translated into several languages. Original textbooks in semiotics have been written and published in at least 22 languages. Taking also into account the translations (altogether 32 languages, see the bibliography), we can observe the following publication dynamics: in the 1960s - 7 books; in the 1970s - 45 books; in the 1980s - 37 books; in the 1990s 54 books, in the 2000s - 62 books (see also Table 2, and Fig. 1).

Table 2. The number of introductory books published. The two last rows give the data for published lexicons and readers. Only first editions are taken into account.

\begin{tabular}{|l|c|c|c|c|c|c|}
\hline & 1960 s & 1970 s & 1980 s & 1990 s & 2000 s & sum \\
\hline original titles & 5 & 27 & 27 & 34 & 39 & 132 \\
\hline$\ldots$ in English & 0 & 3 & 9 & 8 & 6 & 26 \\
\hline$\ldots$ in French & 1 & 7 & 1 & 5 & 1 & 15 \\
\hline$\ldots$ in Russian & 1 & 2 & 0 & 1 & 9 & 13 \\
\hline$\ldots$ in Italian & 1 & 4 & 2 & 1 & 8 & 16 \\
\hline$\ldots$ in other languages & 2 & 11 & 15 & 19 & 15 & 62 \\
\hline translated titles & 2 & 18 & 10 & 20 & 23 & 73 \\
\hline encyclopedias and dictionaries & 0 & 6 & 3 & 5 & 9 & 23 \\
\hline anthologies and readers & 0 & 2 & 5 & 4 & 5 & 16 \\
\hline sum (original+translated+lexicons+readers) & 7 & 53 & 45 & 63 & 76 & 244 \\
\hline
\end{tabular}




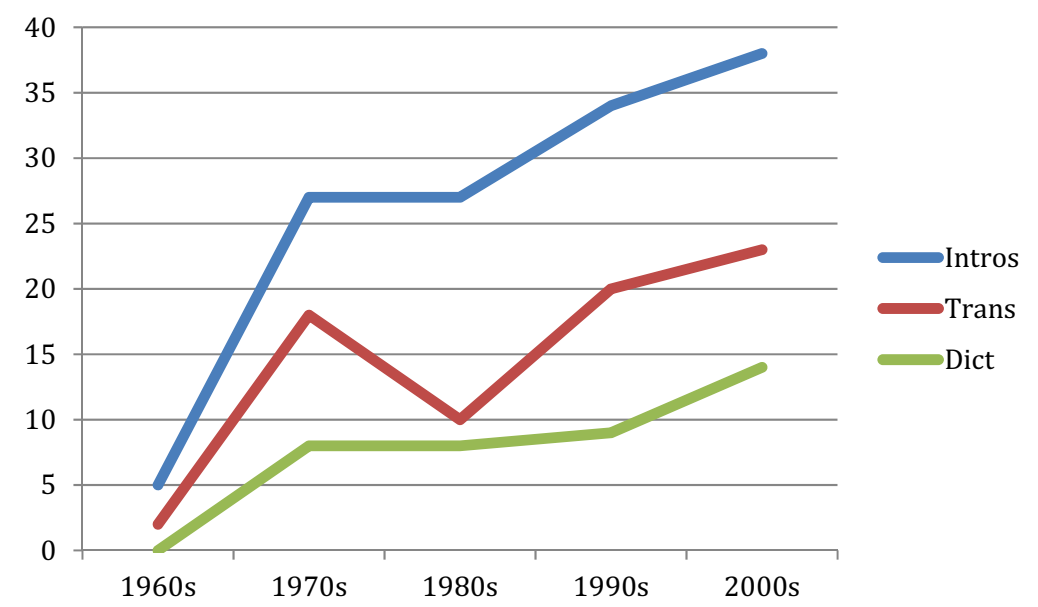

Figure 1. Dynamics of semiotics textbook publication during five decades (first editions only). Intros - all original titles of introductions and textbooks in general semiotics; Trans - translations; Dict - dictionaries and readers.

The publication dynamics allows to draw some conclusions. First, the number of new books published per decade is growing. The growth has not been smooth, however the 1980s witnessed a setback.

If the original books are divided into three groups according to language: (a) English, (b) French, Russian, and Italian, and (c) all other languages, it appears that the trends we observed in the sum curve are not the same for the subgroups (Fig. 2). English-language books and Group (c) reached their maximum in the 1990s, without any setback in the 1980s. The French-Russian-Italian group, however, behaves completely differently there was a rapid growth in the 1970s that was reduced to almost zero in the 1980s, and started to grow again since the 1990s. Interestingly enough, the translation activity (Fig. 1) follows a curve quite similar to that of the French-Russian-Italian group.

Our interpretation for this is as follows. The leading centres in semiotics have been situated in these three language areas - French, Russian, and Italian ${ }^{14}$. In these regions, semiotics was institutionalized earlier than elsewhere, already in the 1960s. The depression after the "post-modern peak" of the 1970s was also most marked in these countries, and the whole new growth since the 1990s comes mainly from the same regions. The translation activity curve obviously follows that of the leading thought. In the Anglo-American region semiotics became institutionalized a bit later and its growth demonstrates a certain inertia. Similarly, the production of semiotics

14 Our method of analysis cannot make specific claims about small languages or countries. 
dictionaries, encyclopedias and readers does not follow the quick changes occurring in the leading regions. We can also hypothesize that since the French-Russian-Italian group demonstrates growth in the 2000s, a new growth in English-language semiotics will follow soon.

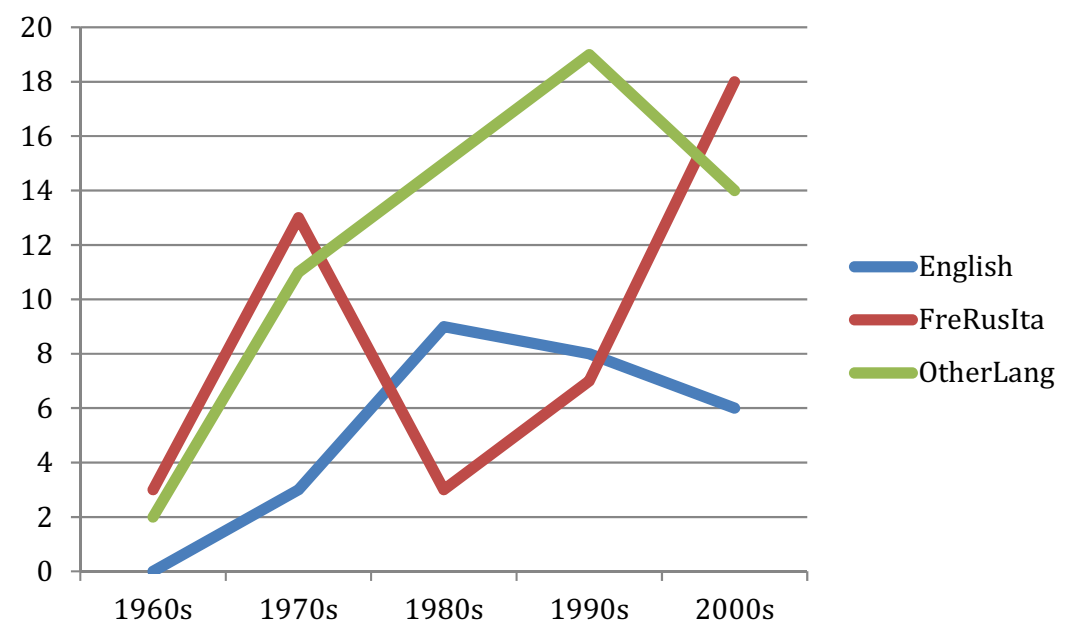

Figure 2. Dynamics of publishing textbooks in semiotics in different languages during five decades: English -English; FreRusIta - French, Russian and Italian; OtherLang - all other languages.

\subsection{General observations and remarks}

Below, we describe some of our observations regarding the trends noticeable in the 'introductions to semiotics' over the 50 years. We have focused on seven questions.

(a) Whether semiotics is seen as a science, philosophy, doctrine, or method.

Notwithstanding the fact that for several decades semiotics has been the subject of ardent academic discussion and scientific scrutiny, there still is some ambiguity as regards its principal designation in contemporary human sciences: what is semiotics per se - is it a scholarly method, a pure scientific discipline, a theory, the general systems theory apparatus, a philosophy, a methodology, a doctrine, an elitist knowledge, a practice, an approach, or just a basis for inter- or transdisciplinarity? This problem has been exciting theorists since the first introduction to semiotics appeared, although giving clear definitions or making references to its status is rare.

It is difficult to summarize the main trends regarding the issue, thus a certain discrepancy can be noticed. The approaches to the status of semiotics vary from country to country and according to the tradition and the authors' background. 
Among the adherents of the scientificity of semiotics are East European (Vetrov, Stepanov, Ageev, Pelc) as well as Italian (Pozzato, Volli, Magli) and some French scholars. Here, the German tradition (Bense, Schönrich, Walther) stands out as an alternative, referring as it does to semiotics as a theory and/or a philosophy. Some authors stress the importance of semiology as primarily a method, an analytical tool (Mounin). The adherents of semiotics as a doctrine (Sebeok) or philosophy (Deely) are predominantly American.

In the late 1980s and 1990s, when the formation of certain fundamentals of semiotics gave way to detailed investigations of the main subfields of semiotics, the overwhelming majority of authors declined to formulate the status of the field, as expressed for instance by Sless (1986: 1): "semiotics is far too important an enterprise to be left to semioticians". It is noticeable that semioticians themselves insist upon its scientificity, whereas those not directly affiliated with semiotics rather see it as a supplementary approach to other sciences. (Still, Chandler (2002: 214) bluntly states, "Semiotics is not, never has been, and seems unlikely ever to be, an academic discipline in its own right.")

At the same time, the definition of the status of semiotics is often rooted in the etymology of terms where semiology as any logos-oriented faculty has more of a likelihood of being called a science than semiotics and linked with the problem of the Saussurean or Peircean approaches to semiotic phenomena: the Saussurean one as linguistics-bound, thus more scientific; the Peircean one as philosophy-bound, thus as if less scientific.

Eco's view on this that semiotics is like medicine does not seem to be widely known as yet.

(b) Are the introductions mainly based on Saussurean or Peircean, or mixed (synthetic, or compilative) approaches; whether the term 'semiotics' or 'semiology' is used.

This is, whether a background of linguistics or logics is dominating. We may assume that European semiotics has preferred the former and American semiotics the latter point of departure. However, "it is accurate to say that semioticians today use a blend of Saussurean and Peircean concepts and techniques at various stages of analysis and for diverse purposes" (Danesi 2007: 22). This seems to be true particularly in case of textbooks.

For instance, Johansen and Larsen (2002: 6) declare that their book "unlike most introductions, emphasizes the importance of bridging between European and American semiotics based on the theories of, respectively Ferdinand de Saussure and Charles Sanders Peirce". V. Tejera's statement (1988: ix) about his book: "Barthes "semiological" terminology, derived from F. de Saussure, has been assimilated without violence into that of Peirce's semiotics" also deserves attention.

There is a great difference, though, between (a) books that remain explicitly true to Peirce (such as Santaella 1983; Merrell 2000); (b) books that are innovative within a Peircean framework (such as Deely 1990); (c) books that include Peirce along with 
other figures (such as Eco 1976; Heradstveit, Bjørgo 1987; Marty, Marty 1992; Cobley 1997; etc.), and (d) books that almost avoid mentioning Peirce’s work (e.g., Mounin 1970; Klinkenberg 1996; Magli 2004).

In Germany the Stuttgart school (e.g., Max Bense, Elisabeth Walther) has relied solely on Peirce's theory of semiotics as a basis of explaining sciences as well as art, calling their approach the basis theory of semiotics (semiotische Basistheorie). The authors who belong to the school have worked on explicating connections between Peirce's various typologies of signs, providing thereby some additional meta-categories.

As regards terminology, a certain language-based division can be observed, as French and Spanish often use 'semiology', whereas English, Russian and German traditions rather prefer 'semiotics'.

The Greimasian approach means using the term 'semiotics', while following the Saussurean tradition. A similar usage is quite common among Italian authors.

What is certainly remarkable is that Peirce's approach was described already in the very first introductory books of the 1960s, despite of the fact that the wider study of Peirce among semioticians only started in the late 1980s, together with a turn towards a more process-based semiotics.

(c) Didactic aspects: do the books include semiotic problems and exercises for students. The books can be divided on the basis of their presumed readership. In some texts it is clearly stated, in others it can be assumed. Various texts that are titled as textbooks do not offer exercises or questions for students, but often refer to further reading on the concepts or theories covered in the chapters (e.g. Volli 2000). Many of the books are rather theoretical (by Deely, Santaella, Eco, Cobley), and in a way contradict their title (e.g. some of the German introductions to semiotics which are clearly on an advanced level of logic - Schönrich 1999; Walther 1974, 1979).

Books by Heradstveit and Bjørgo (1987) and Nöth (1975) are built around numerous concrete case studies that appear throughout the text. Also Pozzato (2001) dedicates separate chapters to analysing examples of literary texts and commercials. Magli's (2004) and Johansen and Larsen's (2002) books offer also didactic exercises. Magli (2004) gives many test questions at the end of each chapter (answers can be found in the preceding text), and also analytical exercises such as "set the boundaries of a particular text", "bring out the repeating motifs in this text" etc. Johansen and Larsen (2002) provide sample analyses to explain the methodology of semiotics. Hall's (2007) very concise book can be highlighted as an example of a didactically elaborate book following the approach of problem-based learning (72 problems, well structured). Similarly, the book by Marty and Marty (1992) formulates 99 basic questions of semiotics and gives short, clearly understandable, yet by no means simplistic answers. 
A large project for introducing semiotics courses in high schools was developed in the Greater Boston Area. It started in 1977 and was led by Donald W. Thomas ${ }^{15}$. This resulted in a four-volume set of study materials in semiotics (Thomas 1977, 1978, 1982, 1983).

Kreidlin and Krongauz (1997) have written quite an exceptional textbook, as it offers a wide range of exercises primarily directed towards primary school children. Exercises complement the theoretical part of the textbook by illustrating the described signsystems-related phenomena or linking their personal observations with the semiotic theory. Similarly, also Berger (1984) gives examples from everyday life and pop culture to illustrate the various sign functions.

Alvarez Sanagustín et al. (1992) offer another example in the form of a compendium of lecture materials based on a collectively read course, which also includes a chapter on the previously printed textbooks.

In general, one can say that the introductory books have become more and more to resemble textbooks, which is quite logical, as in the 1960s and 1970s semiotics had to introduce itself as a new discipline for which giving background knowledge and general information was necessary, while in the 1990s and especially in the 2000s new centres for teaching semiotics as a separate discipline not related to linguistics or communication or media studies anymore were established and a demand for textbooks grew. Together with semiotics becoming a kind of a fashionable term, the demand for basic books that would apply modern pedagogical approaches arose (such as Marty, Marty 1992, or Cobley, Jansz 1997, or Hall 2007).

(d) Applied aspects: Which of these books include guides for practical semiotic analysis? The methods of empirical semiotic research, in which the qualitative methods are generalized so that these could be used in case of quite different sign systems (see Manning 1987; Berger 1984), have appeared in introductory books since the 1980s, and show a tendency of becoming increasingly more important. At first applied semiotic analysis was used in examples of literary text analysis (Scholes 1982). Berger's (1984) book also stands out for his comic approach and numerous visual and popculture-related examples. Several other books include sample analyses (Lidov 1999; Leeds-Hurwitz 1993; Heradstveit, Bjørgo 1987; Merrell 2000). In the past decade, some good examples of visual semiotic analysis have been published (Crow 2003) and visual examples have been used for sample analyses (Hall 2007). Pozzato (2001) and Magli (2004) reserve separate chapters for examples of different textual analyses. The book by Roventa-Frumusani and Gaudreault (2001) includes concrete practical tasks for students. Nikitina (2006) describes three different semiotic methods: the linguistic (theoretical), the experimental, and the hermeneutical (rhetorical analysis, interpretation) one.

15 Thomas, Donald W. 1983. A Course in Semiotics for High Schools. Project Report \#10 (Grant \#NEH ES 27221-77-300.) Bedford: Project Semiotics. 
There are very few textbooks that would take the position of a methodological guidebook or even tool-kit of semiotics (exceptions are, e.g., Scholes 1982; Silverman 1983). In most cases, the guidance and instructions for carrying out semiotic analyses are not a strong side of the semiotics textbooks observed. A great exception is Louis Hebert's (2011, available as e-book only) Tools for Text and Image Analysis: An Introduction to Applied Semiotics which provides detailed descriptions for the methods of semiotic analysis.

(e) How wide is the scope of semiotics as described in each case?

The scope of semiotics as covered in introductory textbooks is rather wide and varied. Besides the most common fields of communication, structuralism, literature and language, it often includes also biosemiotics and sociosemiotics.

While episodic in general, the very first appearance of biosemiotic chapters can be found already in the books by Vetrov (1968) and Stepanov (1971). In contrast, the field of sociosemiotics appears explicitly relatively late. For example, the elaborate-discussion on discourse appears only in Johansen and Larsen (1994), discourse in the context of sociosemiotics in Pozzato (2001), and sociosemiotics tied to imagology in Pocheptsov (2002). Nevertheless, many concepts central to the social dimension of semiotics (e.g. text, communication, pragmatism, interaction, aspects of politics and propaganda, etc.) are independently present earlier than that.

Also semiotics of culture as a separate field distinct from semiotics of communication, literature and language can be found relatively late (in Santaella 1983; Tarasti 1990; Veivo, Huttunen 1999). While introduction of pop culture, media and film as objects of semiotics was interpreted through the general cultural context of the 1980s (e.g. Berger 1984), it might be more surprising that a chapter on semiotic problems of linguistics did not appear before the mid-1970s, while the first introductory books are characterized by their much more general scope.

The popular image of semiotics is reflected in the tendency to concentrate on communication, media, literature, visual examples and tricky examples from everyday behaviour in textbooks targeted at beginners. The fields and approaches of biosemiotics and sociosemiotics are explicitly presented mostly in books targeted at intermediate or even advanced levels (e.g. biosemiotics in Deely 1990; Sebeok 1993; Stepanov 1971; and the sociosemiotic approach in Tejera 1988; Pozzato 2001).

While an explicit discussion of the semiotic threshold can be found in Eco (1976), more elaborate and critical discussion follows in Deely (1990) and Sebeok (1993). In some books, the semiotic threshold is stated without a longer discussion (e.g., according to Hall 2007, the meaning is created in society).

The 2000s see an increase in the semiotics of everyday behaviour, which, as material, does not broaden the theoretical scope, but widens the practical applicability of semiotics. 
(f) Which are the national or geographical differences.

We should ask about the general inclinations and methods presented in textbooks of semiotics worldwide: are there differences deriving from geographical or language-based "borders". The question of language and geography brings up questions of cultural heritage, invasions, translations, and mythology of thinking - or the principles on which describing of the world as a united whole is standing. Textbooks in semiotics seem to express the authors inner need to provide some mapping tools to help to reach an understanding of what is hidden behind our language and signs, and from that point of view, we are not free from the ideologies that have been shaping the mind the understanding of writer. Differences by country and language exist and are worth paying attention to.

For instance, most of the textbooks in Italian focus on the semiotics of text, using sources such as Greimas, Propp, Eco, Lotman, communication and media studies (Pozzato 2001; Magli 2004; Volli 2006), as well as sociosemiotics, including the semiotic analysis of everyday objects, brands and commercials. Biosemiotics and treatment of non-human species are usually missing. Gensini's (2002) book in Italian is an exception, but he rather studies animals in order to compare their anatomical apparatus to that of humans and understand how the ability of speaking and language skills develop. Still, he also mentions the distinctions between human semiosis and non-human animal semiosis.

At first sight, the French School seems to be dominated by structuralism (Barthes 1964) and an evolution of Saussurean thought in connection with the Prague School and Russian formalism (Kristeva, Althusser). This, however would sadly underestimate the breadth of the intellectual base of textbooks in French - there are many texts which comprehensively describe vast areas of semiotic theories, models and terminology (Roventa-Frumusani, Gaudreault 2001; Klinkenberg 1996), and already the influential dictionary by Greimas and Courtés (1979) attempted to include the views of different schools.

Textbooks in German (e.g., Bense 1967) more often than others do not forget to use and develop the works of Peirce, Frege, Locke, Lambert, Hegel and Morris.

Textbooks in Denmark and Norway attempt to synthesize structuralism and pragmatism, developing the vast area of semiotic research from language-based models (Kjørup 2002) to practical political analysis (Heradstveit, Bjørgo 1987).

Writers of Russian-language textbooks tend to describe the diversity of tendencies in the sphere of theory of semiotics, though building it on preferably languagebased models (from animals to cybernetic machines) (Vetrov 1968; Barulin 2002; Mechkovskaja 2004; Nikitina 2006). Russian authors propose their original approaches to the basic semiotic theory (e.g. Solomonik 2004) maybe more often than others.

\section{(g) What is said about the future of semiotics?}

A potential of the field can be demonstrated via the formulation of the not-yet-solved problems, the tasks that are required. Differently from interview books (e.g. Bundgaard, Stjernfelt 2009; see also Kull, Velmezova 2014), textbooks do not use this opportunity often. 


\section{Conclusions}

(1) Quite a rich variety of introductory textbooks on semiotics has been published in English, Italian, Russian, German, Spanish, Portuguese, French, Japanese, and Danish. In most other languages there exist few (if any) books which would meet the needs of an introductory semiotics course.

(2) The whole area of sign systems (living and technical) is covered in a relatively small number of books (by Stepanov, Vetrov, Sebeok, Deely, Gensini, Danesi, Santaella, Mechkovskaya, Barulin, Cobley, Proskurin, Voigt).

(3) It is important to note that when choosing a coursebook for an introductory course on semiotics some texts are preferable bearing in mind students who have no previous knowledge of the field (e.g. Kreidlin, Krongauz). Some books work well to systematize the topics studied (e.g. Cobley), others are good for independent reading (e.g. Barthes; Johansen and Larsen) or for revising the whole material before the exam (e.g. Klinkenberg, Mechkovskaya, Barulin, Hall), whereas many texts are actually the authors' contemplations on important semiotic topics (e.g. Bense, Caprettini, Schönrich).

(4) We can observe a division into writing either practical or theoretical introductions. The practical books are usually very clearly structured and offer plentiful visual materials (graphics, photos, diagrams), together with exercises for students - books by Berger, Hall, and Danesi are good examples here.

(5) Most of the books mix the Peircean and the Saussurean models. Both classics were included already in the 1960s, and we have not been able to detect any clear general trend towards preferring either of these schools in the textbooks on semiotics.

(6) We can observe a steady tendency towards an increase in the publication of introductions to semiotics.

Acknowledgements. We thank Han-liang Chang, Angie Juipi Chien, Paul Cobley, Marcel Danesi, Claus Emmeche, Winfried Nöth, Margus Ott, Imants Frederiks Ozols, Vitali Poskin, Vadim Verenitš, for their helpful input and comments. The work is related to the project IUT2-44. The current review has been compiled as a preparation for writing a new textbook in semiotics by a team of the Department of Semiotics at the University of Tartu, Estonia. 


\section{References (general and secondary sources)}

Bundgaard, Peer; Stjernfelt, Frederik (eds.) 2009. Signs and Meaning: 5 Questions. New York: Automatic Press, VIP.

Culler, Jonathan 1975. Structuralist Poetics. London: Routledge \& Kegan Paul.

- 1981. The Pursuit of Signs: Semiotics, Literature, Deconstruction. London: Routledge.

Danesi, Marcel 1991. Teaching semiotics: The textbook issue. The Semiotic Review of Books 2(3): 6-7.

Deely, John 2001. Four Ages of Understanding: The First Postmodern Survey of Philosophy from Ancient Times to the Turn of the Twenty-First Century. Toronto: University of Toronto Press.

Eimermacher, Karl; Shishkoff, Serge 1977. Subject Bibliography of Soviet Semiotics: The MoscowTartu School. Ann Arbor: Dept. of Slavic Languages and Literatures, University of Michigan.

Eschbach, Achim 1974. Zeichen, Text, Bedeutung: Bibliographie zu Theorie und Praxis der Semiotik. München: Wilhelm Fink.

Eschbach, Achim; Rader, Wendelin 1976. Semiotik-Bibliographie I. Frankfurt am Main: Syndikat.

Eschbach, Achim; Eschbach-Szabó, Viktória 1986. Bibliography of Semiotics 1975-1986. 2 vols. Amsterdam: Benjamins.

Fabbri, Paolo 2003[1998]. La svolta semiotica. Roma: Editori Laterza.

Hoffmeyer, Jesper 2008. Biosemiotics. An Examination into the Signs of Life and the Life of Signs. Scranton: University of Scranton Press.

Krampen, Martin; Oehler, Klaus; Posner, Roland; Uexküll, Thure von (eds.) 1981. Die Welt als Zeichen: Klassiker der modernen Semiotik. Berlin: Wolf Jobst Siedler Verlag.

Krampen, Martin; Oehler, Klaus; Posner, Roland; Sebeok, Thomas A.; Uexküll, Thure von (eds.) 1987. Classics of Semiotics. New York: Plenum Press.

Kull, Kalevi 2009. The importance of semiotics to University: Semiosis makes the world locally plural. In: Deely, John; Sbrocchi, Leonard G. (eds.), Semiotics 2008: Specialization, Semiosis, Semiotics. Ottawa: Legas, 494-514.

Kull, Kalevi; Salupere, Silvi; Torop, Peeter 2009. Semiotics has no beginning. In: Deely, John, Basics of semiotics. (5th ed.) (Tartu Semiotics Library 4.2.) Tartu: Tartu University Press, xi-xxvii.

Kull, Kalevi; Velmezova, Ekaterina 2014. What is the main challenge for contemporary semiotics? Sign Systems Studies 42(4): 530-548.

Kull, Kalevi; Väli, Katre 2011. Semiotics for University: Semiosis makes the world locally plural. Chinese Semiotic Studies 5(1): 246-272.

Lange-Seidl, Annemarie 1986. Semiotics in East and West Germany and Austria. In: Sebeok, Thomas A.; Umiker-Sebeok, Jean (eds.), The Semiotic Sphere. New York: Plenum Press, 177-227.

Leeuwen, Theo van 2005. Introducing Social Semiotics: An Introductory Textbook. London: Routledge.

Manning, Peter K. 1987. Semiotics and Fieldwork. (Qualitative Research Methods 7.) Newbury Park: SAGE Publications.

Miroshnichenko, I. V. 2007. Semiotika: konspekt lektsij: Posobie dlya podgotovki k ekzamenam. Moscow: A-Prior. [Мирошниченко, И. В. 2007. Семиотика: Конспект лекций: Пособие для подготовки к экзаменам. Москва: А-Приор.]

Mitchell, Martha 1993. Encyclopedia Brunoniana. Providence: Brown University Library. 
Morris, Charles 1946. Signs, Language, and Behavior. New York: Prentice-Hall.

Nöth, Winfried 1996. Thomas A. Sebeok, Signs: An Introduction to Semiotics. Book review. Journal of Pragmatics 26: 567-569.

- 2010. The semiotics of teaching and the teaching of semiotics. In: Semetsky, Inna (ed.), Semiotics Education Experience. Rotterdam: Sense Publishers, 1-19.

Nöth, Winfried; Santaella, Lúcia 1999. Semiótica: Bibliografia comentada. São Paulo: Experimento. Ogden, Charles Kay; Richards, Ivor A. 1923. The Meaning of Meaning: A Study of the Influence of Language upon Thought and of the Science of Symbolism. London: Kegan Paul, Trench, Trubner.

O’Sullivan, Tim; Hartley, John; Saunders, Danny; Montgomery, Martin; Fiske, John 1994. Key Concepts in Communication and Cultural Studies. London: Routledge.

Pelc, Jerzy 1992. Teaching semiotics and its institutionalization. In: Deledalle, Gérard; Balat, Michel; Deledalle-Rhodes, Janice (eds.), Signs of Humanity. (Approaches to Semiotics 197.) Berlin: Mouton de Gruyter, 1749-1760.

Petrilli, Susan; Ponzio, Augusto 2005. Semiotics Unbounded: Interpretive Routes Through the Open Network of Signs. Toronto: University of Toronto Press.

Simpkins, Scott 2001. Literary Semiotics: A Critical Approach. Lanham: Lexington Books.

Sonesson, Göran 1988. Methods and Models in Pictorial Semiotics. Lund: Institute of Art History. Spartz, John M.; Cramer, Jennifer 2006. A sign of the times: A glimpse at semiotics in the academy. In: Prewitt, Terry, J.; Morgan, Wendy; Smith, Benjamin (eds.), Semiotics: 2006-2007. Ottawa: Legas Press, 202-217.

Trabant, Jürgen 1972. Vorwort des Übersetzers. In: Eco, Umberto, Einführung in die Semiotik. München: Fink, 9-14.

Wallon, Henri 1942. De l'acte à la pensée. Paris: Flammarion.

\section{Bibliography}

\section{Encyclopedias, dictionaries, handbooks (general semiotics)}

Ablali, Driss; Ducard, Dominique 2009. Vocabulaire des études sémiotiques et sémiologiques. Paris: Honoré Champion.

Bellert, Irena; Ohlin, Peter 1978. Selected Concepts in Semiotics and Aesthetics: Material for a Glossary. Montreal: Programme in Communications, McGill University.

Bense, Max; Walther, Elisabeth (eds.) 1973. Wörterbuch der Semiotik. Köln: Kiepenheuer \& Witsch.

Bouissac, Paul (ed.) 1998. Encyclopedia of Semiotics. New York: Oxford University Press.

Cobley, Paul (ed.) 2001. The Routledge Companion to Semiotics and Linguistics. London: Routledge.

- (ed.) 2010. The Routledge Companion to Semiotics. London: Routledge.

Colapietro, Vincent M. 1993. Glossary of Semiotics. New York: Paragon House.

- 2000. Rechnik po semiotika. Sofia: Неjz’l. [Колапиетро, Винсент 2000[1993]. Речник по семиотика. София: Издателство “Хейзъл".]

Danesi, Marcel 2000. Encyclopedic Dictionary of Semiotics, Media, and Communications. Toronto: University of Toronto Press.

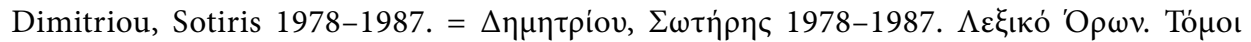

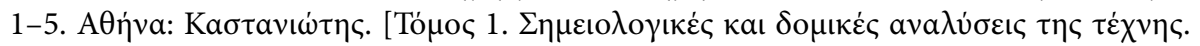

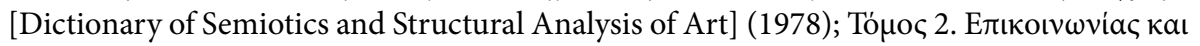




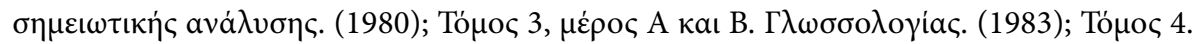

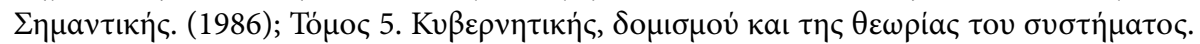
(1987)]. [Dictionary of Communications and Semiotic Analysis. Kastaniotis. 2nd ed. 1988.] Dobrev, Dobrin; Dobreva, Elka 1992. Spravochnik na semotichnite termini. Shumen: Glaukus. [Добрев, Добрин; Добрева, Елка 1992. Справочник на семиотичните термини. Шумен: Глаукус.]

Dutz, Klaus D. 1979. Glossar der semiotischen Terminologie Charles W. Morris'. Münster: Münsteraner Arbeitskreis für Semiotik.

Greimas, Algirdas Julien; Courtés, Joseph 1979; 1986; 1993. Sémiotique: Dictionnaire raisonné de la théorie du langage. 2 vols. Paris: Hachette.

- 1982. Semiotics and Language: An Analytical Dictionary. (Crist, Larry; Patte, Daniel, et al., trans.) Bloomington: Indiana University Press.

- 1982, 1990. Semiótica: Diccionario razonado de la teoría del lenguaje. Madrid: Gredos.

- 1984 (vol 1), 1987 (vol 2). Dicionário de semiótica. São Paulo: Editora Cultrix.

- 1988. Kihohak yongŏ sajŏn. (Ki-sŏk Ch’ŏn, and Tu-han Kim, trans.) Sŏul: Minsŏngsa.

Levchenko, Jan; Salupere, Silvi 1999. Материаль к словарю терминов Тартуско-московской семиотической школы. Conceptual Dictionary of the Tartu-Moscow Semiotic School. (Tartu Semiotics Library 2.) Tartu: Tartu University Press.

Mahlina, Svetlana 2009. Slovar' po semiotike kul'tury. St. Petersburg: Iskusstvo-SРВ. [Махлина, Светлана 2009. Словарь по семиотике культуры. Санкт-Петербург: Искусство-СПБ.]

Martin, Bronwen; Ringham, Felizitas 2000. Dictionary of Semiotics. London: Cassell.

- 2006. Key Terms in Semiotics. London: Continuum.

Nöth, Winfried 1985, 2000. Handbuch der Semiotik. (1st ed. 1985, 2nd ed. 2000.) Stuttgart, Weimar: J. B. Metzler.

- 1990. Handbook of Semiotics. (Series: Advances in Semiotics.) Bloomington: Indiana University Press. Cf. Nöth 1985.

- 2004. Priručnik semiotike: Drugo, posve novoprerađeno i prošireno izdanje. (Series: Biblioteca Teorija 1.) Stamać, Ante, trans. Zagreb: Ceres.

- 2006. Semiotik. (Dharmojo; Jumadi; Setiawat, Eti; Mawene, Aleda, trans.; Ibrahim, Abdul Syukur, eds.) Surabaya: Airlangga University Press.

Posner, Roland; Robering, Klaus; Sebeok, Thomas A. (eds.) 1997-2004. Semiotik/Semiotics: Ein Handbuch zu den Zeichentheoretischen Grundlagen von Natur und Kultur/A Handbook on the Sign-Theoretic Foundations of Nature and Culture. 4 vols. Berlin: Walter de Gruyter.

Rey-Debove, Josette 1979. Lexique Sémiotique. Paris: PUF.

Sebeok, Thomas A. (ed.) 1994 [1986]. Encyclopedic Dictionary of Semiotics. 3 vols. 2nd ed. Berlin: Mouton de Gruyter.

Sebeok, Thomas A.; Danesi, Marcel (eds.) 2010. Encyclopedic Dictionary of Semiotics. 3 vols. 3rd ed. Berlin: Mouton de Gruyter.

Thellefsen, Torkild; Sørensen, Bent (eds.) 2007. Livstegn. Encyklopæedi Semiotik.dk. København: Haase \& Søns Forlag.

Trifonas, Peter Pericles (ed.) 2015. International Handbook of Semiotics. Dordrecht: Springer.

\section{Anthologies and readers (general semiotics)}

Abu Zayd, Nasr Hamid; Kasim, Siza (eds.) 1986. Andimat alalamat fi aloga wa aladab wa atakafa:

Madkhal ila semiotiqa. [The systems of signs in language, literature, and culture: Introduction to semiotics.] Cairo: Elias modern publishing house. 
Blonsky, Martin (ed.) 1985. On Signs. Baltimore: Johns Hopkins University Press.

Boklund-Lagopoulou, Karin; Lagopoulos, Alexandros; Gottdiener, Mark (eds.) 2002. Semiotics. 4 vols. London: Sage.

Bundgaard, Peer F.; Stjernfelt, Frederik (eds.) 2010. Semiotics. 4 vols. London: Routledge.

Clarke, David S. (ed.) 1990. Sources of Semiotic: Readings with Commentary from Antiquity to the Present. Carbondale: Southern Illinois University Press.

Danesi, Marcel; Santeramo, Donato (eds.) 1992. Introducing Semiotics: An Anthology of Readings. Toronto: Canadian Scholar's Press.

- (eds.) 1999. The Sign in Theory and Practice: An Introductory Reader in Semiotics. Toronto: Canadian Scholars' Press.

Deely, John; Williams, Brooke; Kruse, Felicia (eds.) 1986. Frontiers in Semiotics. Bloomington: Indiana University Press.

Fabbri, Paolo; Marrone, Gianfranco (eds.) 2000. Semiotica in Nuce. Volume Primo. I Fondamenti e l'Epistemologia Strutturale. Roma: Meltemi.

- (eds.) 2001. Semiotica in Nuce. Volume Secondo. Teoria del Discorso. Roma: Meltemi.

Favareau, Donald (ed.) 2010. Essential Readings in Biosemiotics: Anthology and Commentary. Berlin: Springer.

Fedorova, Ljudmila L. 2005. Semiotika: Hrestomatiya; Uchebno-metodicheskij modul'. Moscow: Izdatel'stvo Ippolitova. [Федорова, Людмила Львовна 2005. Семиотика: Хрестоматия; Учебно-методический модуль. М.: Изд. Ипполитова.]

Innis, Robert E. (ed.) 1985. Semiotics: An Introductory Anthology. Bloomington: Indiana University Press.

Janus, Elżbieta; Mayenowa, Maria Renata (eds.) 1975. Semiotyka kultury. (Źółkiewski, Stefan, preface.) Warszawa: Państ. Instytut Wydaw.

Maran, Timo; Martinelli, Dario; Turovski, Aleksei (eds.) 2011. Readings in Zoosemiotics. (Semiotics, Communication and Cognition 8.) Berlin: De Gruyter Mouton.

Matejka, Ladislav; Shishkoff, Serge; Suino, Mark E.; Titunik, Irwin R. 1977. Readings in Soviet Semiotics (Russian texts). Ann Arbor: Michigan Slavic Publications.

Mersch, Dieter (ed.) 1998. Zeichen über Zeichen: Texte zur Semiotik von Peirce bis Eco und Derrida. München: dtv.

Perron, Paul; Danesi, Marcel (eds.) 2003. Classic Readings in Semiotics: For Introductory Courses. Ottawa: Legas.

Stepanov, Juri (ed.) 1983. Semiotika. Moscow: Raduga. [Степанов, Ю. С. (ed.) 1983. Семиотика. Москва: Радуга.]

- (ed.) 2001. Semiotika: Antologiya. Moscow: Akademicheskij proekt; Ekaterinburg: Delovaya kniga. [Степанов, Ю. С. (еd.) 2001. Семиотика: Антология. Москва: Академический проект; Екатеринбург: Деловая книга.]

\section{Textbooks and introductions (semiotics in general) \\ In English}

Barthes, Roland 1967[1964]. Elements of Semiology. London: Cape. [Reprints 1969, 1972, 1988.]

- 1968. Elements of Semiology. New York: Hill and Wang. [1st American edition; reprints 1973, 1977, 1990, 1997.]

- 1968. Elements of semiology. New York: Noonday Press. [Reprint 1988.]

Berger, Arthur Asa 1984. Signs in Contemporary Culture: An Introduction to Semiotics. New York: Longman, Inc. 
- 1999[1984]. Signs in Contemporary Culture: An Introduction to Semiotics. Salem: Sheffield Pub. Co.

Chandler, Daniel 2002. Semiotics: The Basics. London: Routledge.

- 2007. Semiotics: The Basics. 2nd ed. London: Routledge.

Clarke, David S. 1987. Principles of Semiotic. London: Routledge \& Kegan Paul.

Cobley, Paul; Jansz, Litza 1997. Semiotics for Beginners. Cambridge: Icon Books.

- 2004. Introducing Semiotics. (Appignanesi, Richard, ed.) Royston: Icon Books.

- 2005. Introducing Semiotics. (Appignanesi, Richard, ed.) New York: Totem Books.

- 2007. Introducing Semiotics. Cambridge: Icon Books.

- 2010. Introducing Semiotics: A Graphic Guide. Cambridge: Icon Books.

Crow, David 2003. Visible Signs: An Introduction to Semiotics. New York: AVA Publishing. [Also 2007.]

Danesi, Marcel 1994. Messages and Meanings: An Introduction to Semiotics. Toronto: Canadian Scholars' Press.

- 1998. Sign, Thought and Culture: A Basic Course in Semiotics. Toronto: Canadian Scholars' Press. [2nd ed.; 1st ed. 1994 under title Messages and Meanings.]

- 1999. Of Cigarettes, High Heels, and Other Interesting Things: An Introduction to Semiotics. New York: St Martin's Press.

- 2004. Messages, Signs and Meanings: A Basic Textbook in Semiotics and Communication Theory. Toronto: Canadian Scholars' Press. [3rd ed.; 1st ed. 1994 under title Messages and Meanings; 2nd ed. 1998 under title Sign, Thought and Culture.]

- 2007. The Quest for Meaning: A Guide to Semiotic Theory and Practice. Toronto: University of Toronto Press.

Deely, John 1982. Introducing Semiotic: Its History and Doctrine. Bloomington: Indiana University Press.

- 1990. Basics of Semiotics. Bloomington: Indiana University Press.

- 2005. Basics of Semiotics. 4th bilingual ed. (Tartu Semiotics Library 4.) Tartu: Tartu University Press.

- 2009. Basics of Semiotics. 5th ed. (Tartu Semiotics Library 4.2.) Tartu: Tartu University Press.

Eco, Umberto 1976. A Theory of Semiotics. (Series: Advances in Semiotics.) Bloomington: Indiana University Press. [1977, London: MacMillan Press.]

Guiraud, Pierre 1975 [1971]. Semiology. (Gross, George, trans.) London: Routledge and Kegan Paul.

Hall, Sean 2007. This Means This, This Means That: A User's Guide to Semiotics. London: Laurence King. [2nd ed. 2012.]

Hawkes, Terence 1977. Structuralism and Semiotics. London: Methuen. [Reprinted 1983; reprinted by Routledge, London 1991, 1992, 1997, 2003; 2nd ed. 2003, reprinted 2005.]

Johansen, Jørgen D.; Larsen, Svend E. 2002[1994]. Signs in Use: An Introduction to Semiotics. London: Routledge.

Kim, Kyong L. 1996[1994 in Korean]. Caged in our own Signs: A Book about Semiotics. Westport: Ablex Publishing.

Leeds-Hurwitz, Wendy 1993. Semiotics and Communication: Signs, Codes, Cultures. Hillsdale: Lawrence Erlbaum Associates Publishers.

Lidov, David 1999. Elements of Semiotics. (Series: Semaphores and Signs.) New York: St. Martin's Press. 
Merrell, Floyd 2000. Signs for Everybody, or Chaos Quandaries and Communication. New York: Legas.

Pap, Leo 1991. Semiotics: An Intergrative Survey. Toronto: Semiotic Circle.

Proskurin, Sergei G. 2007. Essays on Current Semiotics: The Textbook to the Course of "Semiotics". 2nd edition. Novosibirsk: Novosibirsk State University.

Scholes, Robert 1982. Semiotics and Interpretation. New Haven: Yale University Press.

Sebeok, Thomas A. 1994. Signs: An Introduction to Semiotics. Toronto: University of Toronto Press. (Also published as An Introduction to Semiotics, 1994. London: Pinter.)

Silverman, Kaja 1983. The Subject of Semiotics. New York: Oxford University Press.

Sless, David 1986. In Search of Semiotics. London: Croom Helm.

Solomon, Jack 1988. The Signs of Our Time: Semiotics, the Hidden Messages of Environments, Objects and Cultural Images. Los Angeles: Jeremy P. Tarcher.

Solomon, Jack 1988. The Signs of Our Time: The Secret Meanings of Everyday Life. New York: Harper \& Row. (1990 HarperCollins, 2000 Harper Perennial.)

Tejera, Victorino 1988. Semiotics from Peirce to Barthes: A Conceptual Introduction to the Study of Communication, Interpretation, and Expression. Leiden: Brill.

Thomas, Donald Wilcox 1973. Semiotics: A study of Signs and Systems of Communication.

- 1977. Semiotics 1: Signs, Language \& Reality. Lexington: Xerox Individualized Publishing.

- 1978. Semiotics 2: Communication in Man \& Beast. Lexington: Xerox Individualized Publishing.

- 1982. Semiotics 3: Communication, Codes \& Culture. Lexington: Ginn Custom Publishing.

- 1983. Semiotics 4: Language in the Making. Lexington: Ginn Custom Publishing.

\section{In Albanian}

Eco, Umberto 1996[1968]. Struktura e papranishme: kërkimi semiotik dhe metoda strukturale. (Biblioteka Fryma, 10.) Pejë: Dukagjini.

\section{In Arabic}

Barthes, Roland 1986[1964]. Mabādia fī ailm al-adillah. [Elements of Semiology.] (Muhammad Bakri, trans.) Casablanca: Aioun Almakalat editions.

Chandler, Daniel 2008[2002]. Asuss al-sīmiyāaīyāt. [Semiotics: The Basics.] (Talal Wehbe, trans.) S.l.: Arab Organization for Translation.

Cobley, Paul; Jansz, Litza 2005[1997]. Ailm alalamat. [Introducing Semiotics: A Graphic Guide.] (Jamal Aljaziri, trans.) S.l.: Supreme-Council-Of-Culture in Egypt.

Mubarak, Ḥanun 1987. Durūs fī al-sīmiyāaīyāt. [Lessons in semiotics.] Casablanca: Dār Tūquāl. Toussaint, Bernard 1994[1978]. Mā hiya al-sīmiyūlūjiyā? [What is semiotics?] (Nadif Muḥammad, trans.) Casablanca: Afrīqiyā al-Sharq.

\section{In Bulgarian}

Bankov, Kristian 2001. Semotichni tetradki. Uvodni lektsii po semiotika 1. Sofia: NBU. [Банков, К. 2001. Семиотични тетрадки. Уводни текции по семиотика 1. София: НБУ.]

- 2004. Semotichni tetradki. Uvodni lektsii po semiotika 2. Sofia: NBU. [Семиотични тетрадки. Уводни лекции по семиотика 2. София: НБУ.]

Milenkova-Kien, Rositsa 1999. Uvod v semotikata. Sofia: Sanra. [Миленкова-Киен, Росица 1999. Увод в семиотиката. София: Издателство «Санра».] 


\section{In Chinese}

Barthes, Roland 1987. Fu hao xue mei xue. (Mei xue yi wen cong shu.) Shenyang Shi: Liaoning ren min chu ban she. (Dong, X.; Wang, K. trans.)

- 1992. Fu hao xue mei xue. (Yi shu ping lun cong shu, 8.) Taibei: Shang ding wen hua chu ban she. = 羅蘭 - 巴特著; 董學文, 王葵譯. 董學文. 王葵. (1992). 符號學美學. 商鼎文化 出版社 (Dong, X.; Wang, K. trans.)

- 1999. Fu hao xue yuan li [Elements of semiotics]. Falanxi si xiang wen hua cong shu. Beijing: San lian shu dian. = 羅蘭・巴爾特著; 王東亮等譯. (1999). 符號學原理. 三聯書店. (Wang, D. trans.)

Cobley, Paul; Jansz, Litza 2009. [VIZ Semiotics.] Anhui Literature and Art Publishing House. Deely, John 2010. [Basics of Semiotics]. Expanded 6th ed. Beijing: RenMin University Press.

He, Xiuhuang 1965 [Introduction to semiotics.] Taipei: Wenxing. = 何秀煌著1965。記號學 導論, 文星書局, 台北。

Gu, Tiangong 1984. [Semiotics of poetry. Taipei: Dongda Tushu.]=古添洪著 1984。記號詩 學, 東大圖書公司, 台北。]

Gao, Xinyong 1987. [Study of form and name, and theory of narrative. Taipei: Lianjing. $=$ 高辛 勇著 1987。形名學與敘事理論, 聯經出版公司, 台北。

Li, Youzheng 2006. Lilun Fuhaoxue Daolun [Introduction to Theoretical Semiotics]. Beijing: People's University Press.

\section{In Croatian}

Cobley, Paul; Jansz, Litza 2006. Semiotika za početnike. (Radman, Vivijana, trans.) Zagreb: Jesenski i Turk.

Eco, Umberto 2006[2003]. Otprilike isto: iskustva prevođenja. (Raspudić, Nino, trans.) Zagreb: Algoritam.

Johansen, Jørgen; Larsen, Svend Erik 2000. Uvod u semiotiku. Zagreb: Croatialiber.

\section{In Czech}

Černý, Jiř́i; Holeš, Jan 2004. Sémiotika. Praha: Portál.

Doubravová, Jarmila 2002. Sémiotika v teorii a praxi. Promèny a stav oboru do konce 20. století. Praha: Portál.

Eco, Umberto 2004. Teorie sémiotiky. Brno: Janáčkova akademie múzických uměni. (2009. Teorie sémiotiky. Praha: Argo.)

Gvoždiak, Vít 2014. Základy sémiotiky, 1, 2. Olomouc: Univerzita Palackého v Olomouci.

Hawkes, Terence 1999[1977]. Strukturalismus a sémiotika. (Trávníčková, Olga, trans.) Brno: Host.

\section{In Danish}

Dinesen, Anne Marie 1994. Grundbog i semiotik. København: Akademisk Forlag A/S.

Egebak, Niels 1972. Fra tegnfunktion til tekstfunktion: Introduktion til semiologi. København.

Gall Jørgensen, Keld 1993. Semiotik: En introduksjon. København: Gyldendal.

Kjørup, Søren 2002. Semiotik. Roskilde: Roskilde universitetsforlag.

Johansen, Jørgen; Larsen, Svend Erik 1994. Tegn i brug. København: Amanda. 


\section{In Dutch}

Zoest, Aart J. A. van 1978. Semiotiek: over tekens, hoe ze werken en wat we ermee doen. [Semiotics: on signs, how they work and what we do with them.] Baarn: Basisboeken Ambo.

\section{In Estonian}

Cobley, Paul; Jansz, Litza 2002. Juhatus semiootikasse. Tallinn: Koge.

Deely, John 2005. Semiootika alused. (Tartu Semiotics Library 4.) Tartu: Tartu Ülikooli Kirjastus. [Bilingual edition.]

- 2009. Semiootika alused. (Tartu Semiotics Library 4.1.) Tartu: Tartu Ülikooli Kirjastus.

\section{In Finnish}

Cobley, Paul; Jansz, Litza 1998. Semiotiikkaa vasta-alkaville ja edistyville. Helsinki: Jalava.

Tarasti, Eero 1990. Johdatusta semiotiikkaan: Esseitä taiteen ja kulttuurin merkkijärjestelmistä. Helsinki: Gaudeamus.

Veivo, Harri; Huttunen, Tomi 1999. Semiotiikka: merkeistä mieleen ja kulttuuriin. Helsinki: Edita.

\section{In French}

Barthes, Roland 1964. Eléments de sémiologie. Paris: Seuil. [First published in: Communications 4: 91-141 (1964).]

Boutaud, Jean-Jaques 1999. Sémiotique et communication: Du signe au sens. Paris: L'Harmattan.

Carontini, Enrico; Peraya, Daniel 1975. Le projet sémiotique: Eléments de sémiotique générale. Paris: Jean-Pierre Delarge.

Eco, Umberto 1972[1968]. La Structure absente: Introduction à la recherche sémiotique. [La Struttura assente. Edition revue.] (Uccio Esposito-Torrigiani trans.) Paris: Mercure de France.

Floch, Jean-Marie 2002[1990]. Sémiotique, marketing et communication: Sous les signes, les stratégies. (3. ed.) Paris: Presses Universitaires de France - PUF.

Greimas, Algirdas Julien 1976. Sémiotique et sciences sociales. Paris: Éditions du Seuil.

Guiraud, Pierre 1971. Sémiologie. Paris: P.U.F. (Reprints in 1972 and 1983; series “Que sais-je?”, no. 1421.)

Hénault, Anne 1979. Les enjeux de la sémiotique. Vol. 1. Introduction à la sémiotique générale. Paris: P.U.F.

- 1983. Les enjeux de la sémiotique. Vol. 2. Narratologie, sémiotique générale. Paris: P.U.F.

Klinkenberg, Jean-Marie 1996. Précis de sémiotique générale. Louvain-la-Neuve: De Boeck Université. (Reprint: 2000, Paris: Le Seuil.)

Martinet, Jeanne 1973. Clefs pour la sémiologie. Paris: Seghers.

Marty, Robert; Marty, Claude 1992. 99 réponses sur la sémiotique. Montpellier: Centre régional de documentation pédagogique.

Mounin, Georges 1970. Introduction à la sémiologie. Paris: Les Éditions de Minuit.

Roventa-Frumusani, Daniela; Gaudreault, Romain 2001. Pour connaître la science des signes: Introduction à la sémiotique. Craiova: Editura Fundatiei "Meridian".

Toussaint, Bernard 1978. Qu'est-ce que la sémiologie? Toulouse: Privat.

Verhaegen, Philippe 1993. Introduction à la sémiologie. Louvain-la-Neuve: Academia Bruylant. [2nd ed. 2001.]

- 2010. Signe et communication. Bruxelles: De Boeck. 


\section{In German}

Barthes, Roland 1979. Elemente der Semiologie. (Moldenhauer, Eva, trans.) Frankfurt am Main: Syndikat. (Reprints 1981, 1983, 1988.)

Bense, Max 1967. Semiotik: Allgemeine Theorie der Zeichen. Baden-Baden: Agis.

Bentele, Günter; Bystrina, Ivan 1978. Semiotik: Grundlagen und Probleme. Stuttgart: Kohlhammer.

Eco, Umberto 1972. Einführung in die Semiotik. (Trabant, Jürgen, trans.) München: Fink. [Trans. of La struttura assente, 1968, and Le forme de contenuto. UTB Stuttgart edition in 2002.]

Ivanov, Vjačeslav Vsevolodovič 1985[1976]. Einführung in allgemeine Probleme der Semiotik. Tübingen: Narr. [This is an expanded German translation of Ocherki po istorii semiotiki v SSSR (Essays on the History of Semiotics in the USSR). Moscow: Nauka, 1976.]

Keller, Rudi 1995. Zeichentheorie: Zu einer Theorie semiotischen Wissens. Tübingen: Francke. Kjørup, Søren 2009. Semiotik. (Bense, Elisabeth, trans.) Paderborn: Wilhelm Fink Verlag/UTB. Nöth, Winfried 1975. Semiotik: Eine Einführung mit Beispielen für Reklameanalysen. (Anglistische Arbeitshefte, 8). Tübingen: Max Niemeyer Verlag.

- 1985. Handbuch der Semiotik. Stuttgart: Metzler.

Schönrich, Gerhard 1999. Semiotik zur Einführung. Hamburg: Junius.

Trabant, Jürgen 1996[1976]. Elemente der Semiotik. Tübingen: Francke. [1976, München: Beck.] Volli, Ugo 2002. Semiotik - Eine Einführung in ihre Grundbegriffe. (Petersen, Uwe, trans.) Tübingen: Francke.

Walther, Elisabeth 1974. Allgemeine Zeichenlehre: Einführung in die Grundlagen der Semiotik. Stuttgart: Deutsche Verlags-Anstalt.

- 1979. Allgemeine Zeichenlehre: Einführung in die Grundlagen der Semiotik. Stuttgart: Deutsche Verlags-Anstalt. (2., neu bearbeitete und erweitete Auflage)

\section{In Greek}

Eco, Umberto 1989. Theōria sēmeiōtikēs. (Philosophikē kai politikē vivliothēkē 25.) Athēna: Gnōse.

\section{In Hungarian}

Horányi, Özséb 1975. Jel, jelentés, információ. Budapest: Magvető Kiadó.

- 2006. Jel, jelentés, információ, kép. Budapest: General Press Kiadó.

Horányi, Özséb; Szépe, György (eds.) 2005. A jel tudománya - szemiotika. Budapest: General Press Kiadó.

Erzsébet, Cs. Jonás 2004. Ismerkedjünk a szemiotikával! Nyiregyhaza: Krúdy Kiadó.

Sztyepanov, Ju. Sz. 1976. Szemiotika. Budapest. [Translation of Stepanov 1971, from Russian.] Voigt, Vilmos 2008. Bevezetés a szemiotikába. Budapest: Loisir Kiadó.

\section{In Indonesian}

Cobley, Paul; Jansz, Litza 2002. Mengenal semiotika for beginners. Bandung: Mizan.

Danesi, Marcel 2012. Pesan, Tanda dan Makna. [Messages, Signs and Meanings.] Yogyakarta. Jalasutra.

Sudjiman, Panuti H. M.; Zoest, Aart van 1992. Serba-Serbi Semiotika. [All about Semiotics.] Jakarta: Gramedia.

Zoest, Aart van 1993. Semiotika: Tentang Tanda, Cara Kerjanya dan Apa yang Kita Lakukan Dengannya. [Semiotics: About Signs, How It Works and What Do We Do With it.] Jakarta: Yayasan Sumber Agung. 


\section{In Italian}

Barthes, Roland 1966, 1992. Elementi di semiologia. (Bonomi, Andrea, trans.). Torino: Einaudi. [Reprint 1970.]

Bettetini, Gianfranco; Calabrese, Omar; Lorusso, Anna Maria; Violi, Patrizia; Volli, Ugo (eds.) 2005. Semiotica. Milano: Rafaello Cortina Editore.

Calabrese, Omar 2001. Breve storia della semiotica: Dai Presocratici a Hegel. Milano: Feltrinelli. Calabrese, Omar; Mucci, Egidio 1975. Guida a la semiotica. Firenze: Sansoni.

Caprettini, Gian Paolo 1980. Aspetti della semiotica: Principi e storia. Torino: Piccola Biblioteca Einaudi.

Casetti, Francesco 1977. Semiotica: saggio critico, testimonianze, documenti. Milano: Accademia.

De Mauro, Tullio 1971. Introduzione alla semantica. Bari: Laterza.

Eco, Umberto 1968. La struttura assente: Introduzione alla ricerca semiologica. Milano: Bompiani. (Reprinted in 2002: La struttura assente: La ricerca semiotica e il metodo strutturale. Milano: Bompiani.)

- 1975. Trattato di semiotica generale. Milano: Bompiani. [Reprinted in 1978 (6th ed.), 1985 (9th ed.) 2002.]

Fadda, Emanuele 2003. Piccolo corso di semiotica. Acireale: Bonanno. [Also 2004; 2005.]

Gensini, Stefano 2002. Elementi di semiotica. Roma: Carocci editore.

Magli, Patrizia 2005[2004]. Semiotica: Teoria, metodi, analisi. Venezia: Marsilio.

Mariani Ciampicacigli, Franca 1985. Guida a una semiotica per la scuola. (Guide di paideia 8.) Roma: Riuniti.

Marsciani, Francesco 2003[1999]. Esercizi di semiotica generativa: Dalle parole alle cose. Bologna: Esculapio.

Pozzato, Maria Pia 2004[2001]. Semiotica del testo: Metodi, autori, esempi. Roma: Carocci editore.

- 2013. Capire la semiotica. Roma: Carocci.

Trabant, Jürgen 1980[1976]. Elementi di semiotica. (Gimmelli, Enzo, trans.) Neapel: Liguori.

Traini, Stefano 2007[2006]. Le due vie della semiotica: Teorie strutturali e interpretative. Milano: Strumenti Bompiani.

- 2013. Le basi della semiotica. Milano: Bompiani.

Volli, Ugo 2000. Manuale di semiotica. Roma / Bari: Gius Laterza \& Figli. [also 2002, 2003; 7th ed. 2005]

- 2006. Manuale di semiotica. Roma: Editori Laterza.

\section{In Japanese}

Cobley, Paul; Jansz, 2000 = ポール コブリー,リッツァジャンス 2000. 記号論 (吉田 成行, trans.) (For beginnersシリーズ) Gendai Shokan.

Eco, Umberto 1996a = U.エーコ 1996 . 記号論 (1) (同時代ライブラリー (270)) (池上 嘉 彦, trans.)

- $1996 \mathrm{~b}=\mathrm{U}$. エーコ 1996 記号論 (2) (同時代ライブラリー (271)) (池上 嘉彦, trans.)

- 1997 = U.エーコ 1997. 記号論入門一記号概念の歴史と分析 (教養諸学シリーズ) (谷 口伊兵衛, trans.)

Ikegami Yoshihiko 1984 = 池上 嘉彦 1984. 記号論への招待 [An invitation to semiotics]. Tokyo: Iwanami Shoten (岩波新書).

Ikegami Yoshihiko; Tosu Norimitsu; Yamanaka Keiichi $1994=$ 池上 嘉彦; 唐須 教光; 山中 桂 一 1994. 文化記号論—ことばのコードと文化のコード (講談社学術文庫)

Nagai Shigeo; Wada Kazuyuki 1989 = 永井成男; 和田和行; 1989 記号論一その論理と哲学 
Nakano Osamu 1984 = 中野収 1984. 気になる人のための記号論入門一気になる現象を 明快に解き明かす最先端の”考え方” (ゴマセレクト)ごま書房

Nando Hisashi 1984 = 南堂久史 1984. 記号論ハンドブック一新しい知の魅惑. 勁草書房 Sezai Yoshio $1970=$ 瀬在 良男 1970. 記号論序説一その歴史と体系. 駿河台出版社

Stepanov, Juri 1997 = ユーリースチェパーノフ、磯谷 孝、藤本 隆 1997. 記号論入門 (1980 1st ed)

Trabant, Jürgen 1979 = ユルゲン・トラバント 1979. 記号論の基礎原理. (谷口 勇, trans.) 南江堂

Tsurumi Shunsuke $1992=$ 鶴見 俊輔 1992. 記号論集 (鶴見俊輔集) 筑摩書房

Unami Akira 1995 = 宇波彰 1995. 記号論の思想 (講談社学術文庫)

Watari Akeshi 2004 = 亘 明志 2004. 記号論と社会学 (リベラ・シリーズ (7))

Yoshida Natsuhiko 1989 = 吉田夏彦 1989. 記号論 (放送大学教材) 放送大学教育振興会

\section{In Korean}

Chandler, David 2006. Semiotics for Beginners (Inkyu Kang, trans.). S.l.: Somyong Publishing Co. Cobley, Paul, Jansz, Litza 2002. Kihohak = Semiotics. (Sŏng-t'aek Cho; Chin-gyŏng Pyŏn, trans.)

(Harutpam ŭi chisik yŏhaeng, 13.) Sŏul T'ŭkpyŏlsi: Kimyŏngsa. [Translation of Introducing semiotics.]

Eco, Umberto 1985. Kihohak iron. (U-sŏk Sŏ, trans.) (Hyŏndae ŭi munhak iron, 6.) Sŏul: Munhak kwa Chisŏngsa.

Kim, Kyŏng-yong 1994. Kihohak iran muŏt inga: kihoŭi uri, uriŭi kiho. Sŏul T'ŭkpyŏlsi: Minŭmsa. [What is semiotics: the symbol of our, our symbols.] [Translation into English: Kim 1996.]

\section{In Latvian}

Agajevs, V. 2005. Semiotika. Rīga: Jumava. [Trans. of Агеев, Владимир 2002, Семиотика.]

\section{In Lithuanian}

Greimas, Algirdas Julien 1989. Semiotika. (Pavilionis, Ronaldas, trans.) Vilnius: Mintis.

Nastopka, Kęstutis 2010. Literatūros semiotika. [Vilnius]: Baltos lankos.

\section{In Norwegian}

Heradstveit, Daniel; Bjørgo, Tore 1987 (1st edition), 1992 (2nd edition). Politisk kommunikasjon: Introduksjon til semiotikk og retorikk [Political communication: Introduction to semiotics and rhetorics]. Oslo: Tano Aschehoug. [5 reprints by 2006.]

\section{In Persian}

Barthes, Roland (محمدى مجيـ مـترجم ؛ بـارت رولان) 1991. 'Anāṣir-i nishānah shināsī.

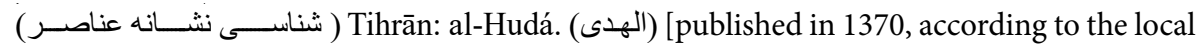
calendar.]

\section{In Polish}

Jadacki, Jacek Juliusz 1996. Metafizyka i semiotyka: Studia prototeoretyczne. Warszawa: Academica.

Marchewka, Feliks Stanislaw 1996. Semiotyka: zarys teorii i jej rozwoju. Kalwaria Zebrzydowska: Wydawnictwo Calvarianum. 
Pelc, Jerzy 1982. Wstęp do semiotyki. Warszawa: Wiedza Powszechna.

Żegleń, Urszula 2000. Wprowadzenie do semiotyki teoretycznej i semiotyki kultury. Toruń: UMK.

\section{In Portuguese}

Barthes, Roland 1971, 1974, 1977, 1993, 1998, 2000. Elementos de semiologia. (Blikstein, Izidoro, trans.) São Paulo: Editora Cultrix.

- 1989. Elementos de semiologia. Edições 70.

Carontini, Enrico; Péraya, Daniel 1979 1975]. O projeto semiótico: Elementos de semiótica geral. São Paulo: Cultrix.

Couto, Hildo Honório do 1983. Uma introdução à semiótica. Rio de Janeiro: Presença.

Deely, John 1990. Semiotica basica. (Pinto, Julio C. M., trans.) São Paulo: Editora Ática.

- 1995. Introdução à semiótica. [Translation of Deely 1982.] Lisboa: Fundação Gulbenkian.

Eco, Umberto. 1976[1968]. A estrutura ausente: introdução à pesquisa semiológica. São Paulo: Perspectiva.

- 1980, 2000. Tratado geral de semiótica. São Paulo: Editora Perspectiva.

Nöth, Winfried 1995, 2003. Panorama da semiótica: De Platão a Peirce. [Panorama of semiotics: From Plato to Peirce.] (Série universidade 33.) 4 editions. São Paulo: Annablume. [Cf. Nöth 2003 - volume 2.]

- 2003. A semiótica no século XX. [Semiotics in the 20th century.] (Coleção E 5). São Paulo: Annablume. [Cf. Nöth 1995, 2003 - volume 1.]

Pinto, Julio; Nova, Vera Casa 2009. Algumas semióticas. Belo Horizonte: Autêntica.

Rodrigues, Adriano Duarte 1991. Introdução à semiótica. Lisboa: Presença.

Santaella, Lucia 1983, 1985, 1986, 1989. O que é semiótica. (Series Coleção primeiros passos 103). São Paulo: Brasiliense. [23 reprints by 1986.]

- 1995. A teoria geral dos signos: Semiose e autogeneração. São Paulo: Ática. [Cf. Santaella 2000, 2nd ed.]

- 2000. A teoria geral dos signos: Como as linguagens significam as coisas. São Paulo: Editora Pionera. [2nd ed. of Santaella 1995.]

Santaella, Lucia; Nöth, Winfried 2004. Comunicação e semiótica. São Paulo: Hacker.

Trabant, Jürgen 1980[1976]. Elementos de semiótica. (Cary, Mary do Carmo trans.) Lissabon: Presença.

\section{In Romanian}

Cobley, Paul; Jansz, Litza 2004. Cîte ceva despre semiotică. (Olivotto, Alexandra, trans.) Bucuresti: Curtea Veche.

Deely, John 1997[1990]. Bazele semioticii. (Net, Mariana, trans.) Bucuresti: All.

Eco, Umberto 2003. Il teorie a semioticii. Bucuresti: Meridiane.

Schveiger, Paul 1984. O introducere ín semiotiká. Bucuresti.

Sebeok, Thomas Albert 2002. Semnele: o introducere în semiotică. (Mărculescu, Sorin, trans.) Bucureşti: Humanitas.

\section{In Russian}

Ageev, Vladimir N. 2002. Semiotica. Moscow: Ves' Mir. [Агеев, Владимир Н. 2002. Семиотика. Москва: Весь Мир.]

Barthes, Roland 1975. Osnovy semiologii. In: Basin, E. Ya; Polyakov, M. Ya. (eds.), Strukturalizm: za i protiv. Moscow: Progress, 114-163. [ Барт, Р. 1975. Основы семиологии. In: Басин, Е. Я.; Поляков, М. Я. (eds.), Структурализм: «за» и «против». Москва: Прогресс, 114-163.] 
Barulin, Aleksandr 2002a. Osnovaniya semiotiki: Znaki, znakovye sistemy, kommunikatsiya. Part 1. Bazovye ponyatiya. Evolyutsionnaya teoriya proishozhdeniya yazyka. (Stepanov, Yu., afterword). Moscow: Sport i kul'tura-2000. [Барулин Александр Николаевич 2002a. Основания семиотики: Знаки, знаковые системы, коммуникация. Ч. 1. Базовые понятия. Эволюиионная теория происхождения языка. (Послесловие Ю. С. Степанова.) Москва: Изд-во “Спорт и культура-2000”.]

- 2002b. Osnovaniya semiotiki: Znaki, znakovye sistemy, kommunikatsiya. Part 2. Kratkaya predystoriya i istoriya semotiki (do Frege, Pirsa i Sossyura). Moscow: Sport i kul'tura-2000. [Барулин Александр Николаевич 2002b. Основания семиотики: Знаки, знаковые системь, коммуникация. Ч. 2. Краткая предыстория и история семиотики (до Фреге, Пирса и Соссюра). Москва: Изд-во «Спорт и культура-2000».]

Eco, Umberto 1998[1968]. Otsutstvuyushchaya struktura: vvedenie v semiologiyu. St.Petersburg: TOO TK “Petropolis". [Отсутствующая структура: Введение в семиологию. СанктПетербург: ТОО ТК «Петрополис».]

Fedorova, Ludmila L. 2004. Semiotika. Uchebno-metoditcheskij modul'. Moscow: Izdatel'stvo Ippolitova. [Фёдорова, Людмила Львовна 2004. Семиотика: Учебно-методический модуль. Москва: Изд. Ипполитова.]

Grinev, Sergei V. 2000. Osnovy semiotiki. Moscow: Mezhd. akad. informatizatsii, sektsiya "Semiotika i informatika". [Гринёв, Сергей Викторович 2000. Основы семиотики. Москва: Межд. акад. информатизации, секция «Семиотика и информатика».]

Grinev-Grinevich, Sergei V.; Sorokina, Elvira A. 2012. Osnovy semiotiki: uchebnoe posobie. Moscow: Flinta Nauka. [Гринев-Гриневич, Сергей Викторович; Сорокина, Эльвира Анатольевна 2012. Основы семиотики: учебное пособие. Москва: Флинта Наука.]

Kreidlin, Grigori E.; Krongauz, Maksim A. 1997. Semiotka, ili azbuka obshcheniya. Moscow: MIROS. [Крейдлин, Г. Е.; Кронгауз, М. А., Семиотика, или азбука общения. Москва: МИРОС.]

Mechkovskaya, Nina B. 2004. Semiotika: Yazyk. Priroda. Kul'tura. Kurs lektsij. Moscow: Izdatel'skij tsentr “Akademiya”. [Мечковская, Нина Борисовна 2004. Семиотика: Язык. Природа. Культура: Курс лекиий. Москва: Издательский центр “Академия”.]

- 2008. Semiotika: Yazyk. Priroda. Kul'tura. Kurs lektsij. (2nd and 3rd eds.) Moscow: Akademiya. [Мечковская, Н. Б. 2008. Семиотика: Язык. Природа. Культура: Курс текиий. (Изд. 2-е и 3-е.) Москва: Академия.]

Nikitina, Jelena S. 2006. Semiotika. Kurs lektsij. Moscow: Akademicheskij proekt; Triksta. [Никитина, Елена Сергеевна 2006. Семиотика. Курс лекций. Москва: Академический проект; Трикста.]

Pocheptsov, Georgij 2009[2002]. Semiotika. 2nd ed. Moscow: SmartBook. [Почепцов, Георгий Георгиевич 2009[2002]. Семиотика. 2-е изд. Москва: SmartBook.]

Proskurin, Sergei G. 2005. Semiotika indoevropejskoj kul'tury: (Uchebnik po kursu "Istoriya yazyka i semiotika”). (2nd, revised ed.) Novosibirsk: SO RAN. [Проскурин, Сергей Геннадьевич 2005. Семиотика индоевропейской культурь: (Учебник по курсу “История языка и семиотика). 2-е издание, переработанное и исправленное. Новосибирск: Издательство CO PAH.]

Schreider, Julius A. 1974. Logika znakovyh sistem (elementy semiotiki). Moscow: Znanie. [Шрейдер, Юлий Анатольевич 1974. Логика знаковых систем (элементы семиотики). Москва: Знание.]

Solomonik, Abram 2004. Pozitivnaya semiotika. Minsk: MET. [Соломоник, Абрам Бенцианович 2004. Позитивная семиотика. Минск: МЕТ.] 
Stepanov, Juri S. 1971. Semiotika. Moscow: Nauka. [Степанов, Ю. С. Семиотика. Москва: Наука.]

Vetrov, Anatolij A. 1968. Semiotika i ee osnovnye problemy. Moscow: Izdatel'stvo politicheskoj literatury. [Ветров, Анатолий Алексеевич 1968. Семиотика и ее основные проблемы. Москва: Издательство политической литературы.]

\section{In Serbian}

Eco, Umberto 1973[1968]. Kultura, informacija, komunikacija. [original La struttura assente] (Drndarski, Mirjana, trans.) Beograd: Nolit.

Giro, Pjer 1975. Semiologija. [translation of Pierre Guiraud, La Sémiologie.] (Vuković, M., trans.) Beograd: BIGZ. (2nd ed. 1983)

\section{In Spanish}

Álvarez Sanagustín, Alberto; Sánchez Trigueros, Antonio; Valles Calatrava, José Rafael (eds.) 1992. Introducción a la semiótica: actas del curso de «Introducción a la Semiótica». (Colección actas 8.) [Almería]: Instituto de Estudios Almerienses, Departamento de Arte y Literatura.

Barthes, Roland 1970. Elementos de semiología. (Corazón, Alberto, ed.; Mendez, Alberto, trans.) Madrid. (Reprint 1971)

Beuchot, Mauricio 1979. Elementos de semiótica. México: Facultad de Filosofía y Letras, UNAM. [2nd ed. 1993, Xalapa: Universidad Veracruzana; 3rd ed. 2001, México: Edito,rial Surge.]

- 2004. La semiótica: teorías del signo y el lenguaje en la historia. México: FCE.

Bobes Naves, María Carmen y otros 1989. La semiología. Madrid: Editorial Síntesis.

Carontini, Enrico; Peraya, Daniel 1979[1975]. Elementos de semiótica general: el proyecto semiótico. (Cardín Garay, Alberto, trans.) Barcelona: Gustavo Gili.

Casetti, Francesco 1980[1977]. Introducción a la semiótica. (Vilches, Lorenzo, trans.) Barcelona: Editorial Fontanella.

Chandler, Daniel 1998. Semiótica para Principiantes (Hogan Vega, Vanessa; Rodrigo Mendizábal, Iván, trans.). Quito, Ecuador: Ediciones Abya-Yala/Escuela de Comunicación Social de la Universidad Politéchnica Salesiana. (Reprinted in 1999; 2001.)

Cobley, Paul; Litza Jansz 2001, 2002. Semiotica para principiantes. Buenos Aires: Errepar.

Crow, David 2008[2003]. No te creas una palabra: una introducción a la semiótica. (Jesús de Cos Pinto trans.) Barcelona: PromoPress.

Deely, John 1996. Los fundamentos de la semiótica. (Beuchot, M., intr.) México: Uia.

Eco, Umberto 1973[1968]. La estructura ausente: introducción a la semiótica. Barcelona: Editorial Lumen. (Reprinted in 1994)

- 1977, 1980, 1995. Tratado de semiotica general. Barcelona: Lumen (1977). [1980, Barcelona: Lumen /Mexico: Nueva Imagen (Mexico); 1995 Barcelona: Lumen.]

Guiraud, Pierre 1972. La Semiología. (Porrazian, María T., trans.) Mexico: SIGLO XXI. (Reprinted in $1979,1988,1989$.

Magariños de Morentin, Juan Angel 1983. El signo: Las fuentes teoricas de la semiologia: Saussure, Peirce, Morris. Buenos Aires: Hachette.

Mounin, Georges 1972[1970]. Introducción a la semiología. Barcelona: Anagrama.

Pedroni, Ana Maria 2004. Semiología, un acercamiento didáctico. 4th ed. Guatemala: Editorial Universitaria.

Pérez Martínez, Herón 1995. En pos del signo: introducción a la semiótica. Zamora, Mich. [Mexico]: El Colegio de Michoacán. 
Sebeok, Thomas A. 1996[1994]. Signos: una introducción a la semiótica. (Paidós Comunicación 74.) Barcelona: Paidós.

Serrano, Sebastià 1981. La semiótica: una introducción a la teoría de los signos. (Biblioteca de divulgación temática 10.) Barcelona: Montesinos.

Velásquez Rodríguez, Carlos Augusto 2006. Teoría de la mentira: Una introducción a la semiótica. San José (Guatemala): ECO ediciones.

Vevia Romero, Fernando Carlos. 2000. Introducción a la semiótica. Guadalajara, Jalisco: Universidad de Guadalajara.

Walther, Elisabeth 1994[1974]. Teoria general de los signos: introduccion a los fundamentos de la semiotica. Santiago: Dolmen.

Zecchetto, Victorino 2003. La danza de los signos: nociones de semiótica general. Buenos Aires: La Crujía.

In Swedish

Eco, Umberto 1971. Den frånvarande strukturen: introduktion till den semiotiska forskningen.

(Tenggren, Estrid, trans.) Lund: Bo Cavefors Bokförlag.

Heradstveit, Daniel; Bjørgo, Tore 1996. Politisk kommunikation: introduktion till semiotik och retorik. Lund: Studentlitteratur.

Kjørup, Søren 2004. Semiotik. (Torhell, Sven-Erik, trans.) Lund: Studentlitteratur AB.

Malmberg, Bertil 1973. Teckenlära: En introduktion till tecknens och symbolernas problematik.

Stockholm: Bokförlaget Aldus/Bonniers.

\section{In Turkish}

Rifat, Mehmet 2009. Göstergebilimin ABC'si. Istanbul: Say.

\section{In Ukrainian}

Deely, John 2000[1997]. Osnovi semiotiki. (2nd, expanded ed.; Karas', Anatolij, trans.). L'viv: Arsenal. [Ділі, Джон 2000[1997]. Основи семіотики. (Друге доповнене видання.) (Карась, Анатолій, trans.) Львів: Арсенал.

\section{Сто введений в семиотику для миллиона студентов: обзор учебников по семиотике по всему миру}

Чтобы оценить состояние учебных пособий по семиотике в настоящее время, мы даем сравнительный обзор вышедших за последние полвека (т.е. с начала институализации семиотики) учебников по семиотике. В обзоре охвачены более 130 книг на более чем 22 языках. Из них примерно 20 вышли и в переводах, поэтому в библиографии представлено 32 языка. Отдельно перечислены антологии и лексиконы. Сравнительный анализ выделяет основные тенденции, которые характеризуют развитие семиотики. В течение всего наблюдаемого периода наблюдается постоянный рост в издании учебников, с незначительным спадом в 1980-е гг. Выделяется ведущая роль французско-, русско- и италоязычной семиотической литературы. 


\section{Sada sissejuhatust semiootikasse, miljonile tudengile: Ülevaade semiootika õpikutest ja sissejuhatavaist raamatutest maailmas}

Et hinnata semiootika õppematerjalide praegust olukorda, esitame maailmas viimasel poolsajandil (s.o. alates semiootika institutsionaliseerumisest) ilmunud semiootika üldõpikute ja sissejuhatuste võrdleva ülevaate ning vastava bibliograafia. Sellesse kategooriasse kuulub enam kui 130 originaalraamatut enam kui 22 keeles. Neist raamatuist umbes 20 on ilmunud ka tõlgetena, mistõttu kokku on bibliograafias esindatud 32 keelt. Eraldi loendeis on toodud seniilmunud semiootika leksikonid ja antoloogiad. Võrdluses näidatakse ka mitmeid tendentse, mis iseloomustavad semiootika arengut nende raamatute alusel alates 1960ndaist. Uute õpperaamatute ilmumise sagedus on olnud aastakümneti kasvav, ajutise langusega 1980ndail. Esile tuleb prantsuse, vene ja itaalia semiootikakirjanduse senine juhtroll. 